\title{
Usage of instructional multimedia to enhance interactivity through Web-based learning in P-12 settings
}

\author{
Sharon L. Teabo \\ West Virginia University
}

Follow this and additional works at: https://researchrepository.wvu.edu/etd

\section{Recommended Citation}

Teabo, Sharon L., "Usage of instructional multimedia to enhance interactivity through Web-based learning in P--12 settings" (2004). Graduate Theses, Dissertations, and Problem Reports. 2576.

https://researchrepository.wvu.edu/etd/2576

This Dissertation is protected by copyright and/or related rights. It has been brought to you by the The Research Repository @ WVU with permission from the rights-holder(s). You are free to use this Dissertation in any way that is permitted by the copyright and related rights legislation that applies to your use. For other uses you must obtain permission from the rights-holder(s) directly, unless additional rights are indicated by a Creative Commons license in the record and/ or on the work itself. This Dissertation has been accepted for inclusion in WVU Graduate Theses, Dissertations, and Problem Reports collection by an authorized administrator of The Research Repository @ WVU.

For more information, please contact researchrepository@mail.wvu.edu. 
Usage of Instructional Multimedia to Enhance Interactivity

Through Web-Based Learning in P-12 Settings

Sharon L. Teabo

Dissertation submitted to the

College of Human Resources and Education

at West Virginia University

in partial fulfillment of the requirements

for the degree of

Doctor of Education
in
Technology Education

John G. Wells, Ph. D., Chair

Clifford A. Harvey, B.F.A.

Edward C. Pytlik, Ph. D

R. Neal Shambaugh, Ph. D.

Jaci L. Webb-Dempsey, Ph. D.

Department of Advanced Educational Studies

Morgantown, West Virginia

2004

Keywords: web-based instruction, Bloom's Taxonomy, Tomei's Taxonomy, multimedia, instructional technology, educational objectives, engagement, PT3, instructional media, interactive

Copyright 2004 Sharon L. Teabo 


\section{ABSTRACT \\ Usage of Instructional Multimedia to Enhance Interactivity \\ Through Web-Based Learning in P-12 Settings}

\section{Sharon L. Teabo}

The purpose of this study was to analyze multiple media as instructional technologies used to enhance interactivity in a web-based environment and to illustrate the potential for improved learning with interactive multimedia. This study identified instructional media that teachers use, the level of engagement with the media, and determined that there was a correlation between the types and use of instructional media and cognitive level of learning.

Research shows that web-based instruction has the ability to engage learners in realworld tasks. This type of authentic learning has the potential to promote higher order thinking provided students are properly skilled in the use of instructional technologies and confident in the use of the web. This study examines the types and use of instructional media integrated in web-based lessons of P-12 study participants.

The correlation between types and use of instructional media and cognitive levels of learning are examined with Bloom's Taxonomy of Educational Objectives and Tomei's Instructional Technology Taxonomy. These two taxonomies were customized to reflect integrated instructional media and associated instructional strategies based on web-units completed by study participants.

An in-depth analysis of an intensity sampling who exhibited high use of active instructional media was conducted to corroborate results gathered through quantitative methods, to add validity to this study, and to examine participants’ perceptions of instructional media and their use.

The study shows a correlation between the types and use of specific instructional media. Specific instructional media were integrated more frequently at low levels on each taxonomy than others. In-depth analysis corroborated findings and analysis of emergent themes yielded additional insight regarding the types and ways in which instructional media were integrated. 


\section{Acknowledgements}

To my committee, each of whom contributed special talents, Dr. John Wells, Clifford Harvey, Dr. Edward Pytlik, Dr. Neal Shambaugh, and Dr. Jaci Webb-Dempsey. Thank you all for your suggestions and the many hours of thoughtful discussions and comments. To my reviewers for their patience, editing, and coaching skills. To the participants of Trek 21, especially those who agreed to be interviewed, and project evaluators for contributing to a pleasurable working and learning experience. Finally, to my friends, colleagues and students at the institutions where I worked throughout the course of my doctoral studies, thank you for your contributions and support. 
Table of Contents

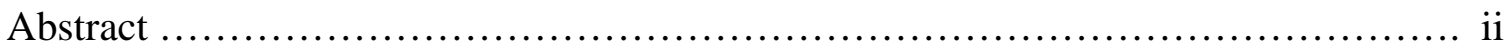

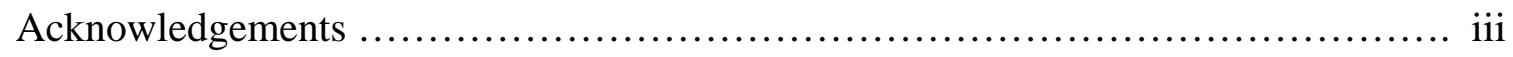

Table of Contents ........................................................... viii

List of Tables ............................................................ vi

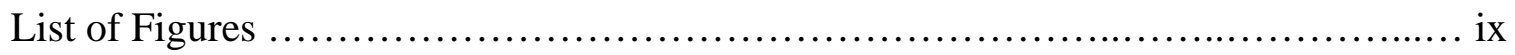

Chapter 1 Problem Statement ................................................. 1

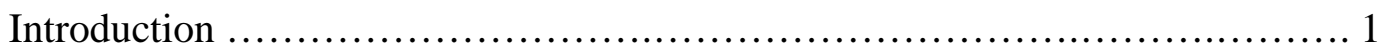

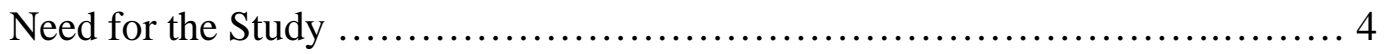

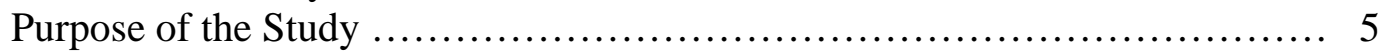

Research Questions ................................................. 5

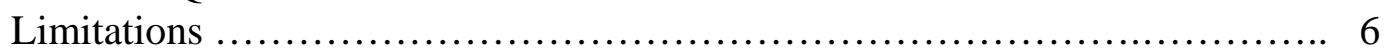

Overview of Methodology ............................................. 6

Definition of Key Terms .............................................. 10

Chapter 2 Review of the Literature ............................................... 12

Introduction ....................................................... 12

Media as Instructional Technologies ..................................... 12

Multimedia ......................................................... 14

Interactive Media ..................................................... 15

Taxonomies........................................................... 16

Bloom's Taxonomy of Educational Objectives .......................17

Tomei's Technology Taxonomy ................................... 18

Multimedia Learning and the Taxonomies............................... 20

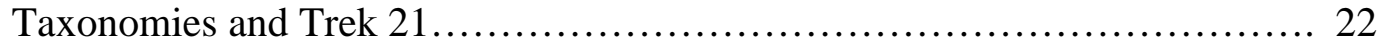

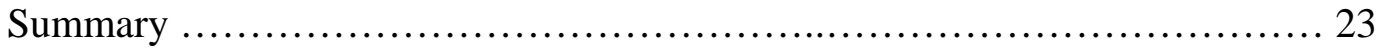

Chapter 3 Methods .......................................................... 24

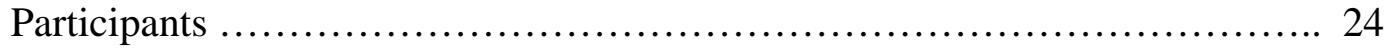

Design and Instrumentation ........................................... 26

Indicators of Instructional Change Instrument-Random Lesson Sweep

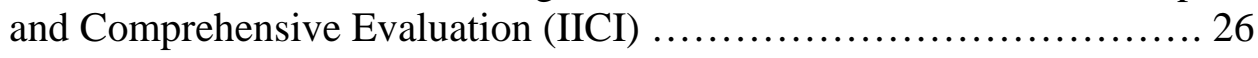

Research Question 1 ......................................... 29

Research Question 2 ........................................... 29

Research Question 3 .............................................. 29

Research Question 4 ............................................ 30

Research Question 5 ............................................ 31

Procedure ...................................................... 32

Data Gathering and Analysis .................................... 32

Research Questions ............................................. 32 


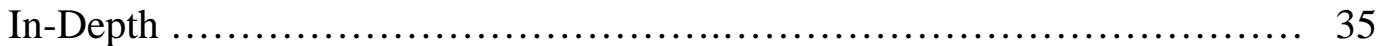

Introduction ....................................................... 35

Limitations .......................................................... 35

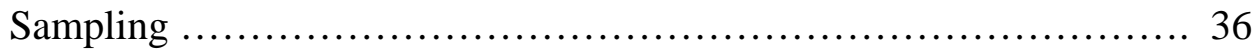

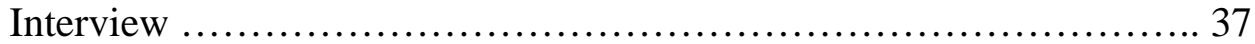

Researcher ......................................................... 39

Stages of Data Analysis .................................................. 40

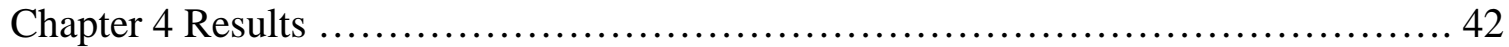

Research Question 1 ................................................... 42

Research Question 2 ................................................ 44

Research Question 3 ................................................... 46

Research Question 4 ................................................... 48

Demographics of Sampling ........................................... 50

Review of Web-based Units ...................................... 51

Customized Taxonomy .............................................. 51

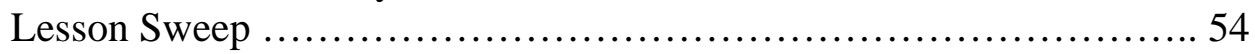

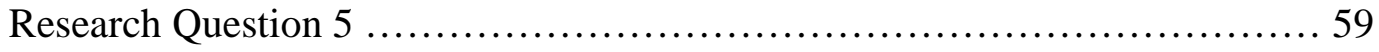

Lesson Sweep ...................................................62

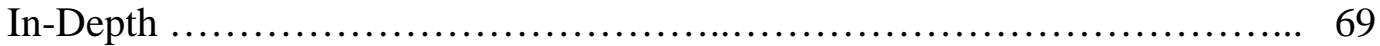

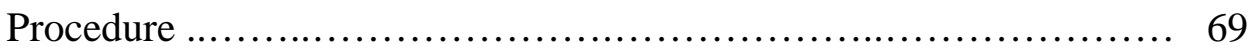

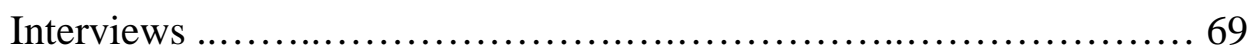

Coding and Data Analysis ..................................... 70

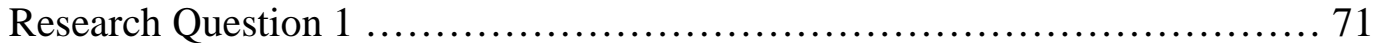

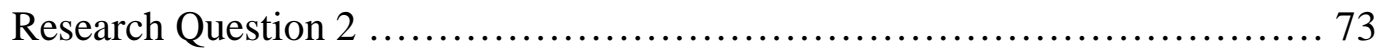

Research Question 3 .............................................. 74

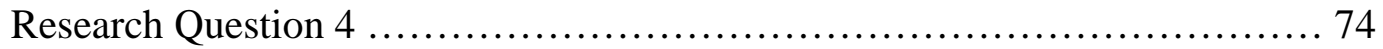

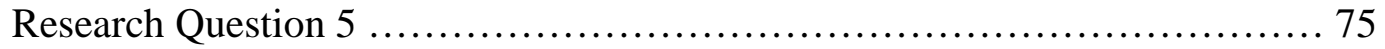

Emergent Themes................................................... 75

Chapter 5 Discussion, Conclusions, Recommendations .......................... 80

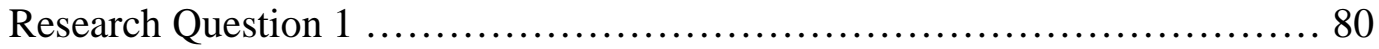

Research Question 2 ................................................ 81

Research Question 3 .................................................. 83

Research Question 4 ....................................................... 84

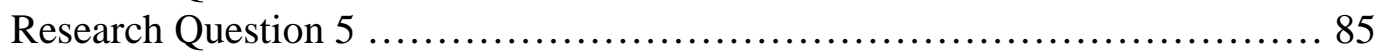

Summary of Conclusions ............................................... 86

Recommendations ................................................... 87

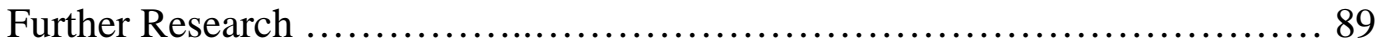

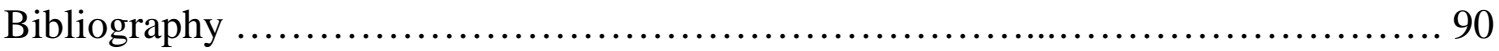


Appendixes

Appendix A .......................................................... 102

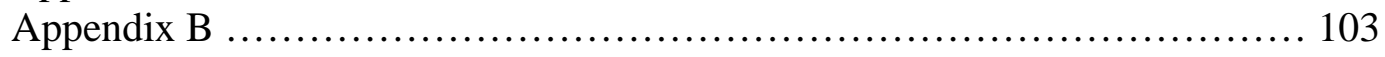

Appendix C ........................................................... 104

Appendix D ............................................................ 105

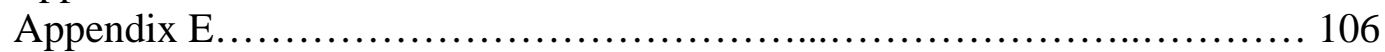

Appendix F ........................................................ 107

Sharon Teabo ...........................................................108 


\section{List of Tables}

Table 1 Judi Harris’ Genres and Telecomputing Activities ............................13

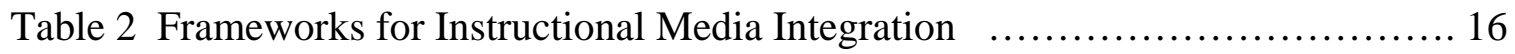

Table 3 Bloom’s and Tomei's Taxonomy: Comparison of Action Verbs................ 19

Table 4 Five Media Forms, Learning Experiences, and Methods ...................... 21

Table 5 P-12 Participant Demographics, Years 1-3 .............................. 25

Table 6 Overview of Research Questions and Instrumentation ....................... 33

Table 7 Frequency of Integration of Instructional Media, Years 1-3 .............. 43

Table 8 Lessons with Three or More Instructional Media .......................... 44

Table 9 Instructional Media and Instructional Strategies Used in Lessons ............. 45

Table 10 Number of Lessons With and Without Instructional Media, Years 1-3 ...... 47

Table 11 Number of Lessons With Active and Non-Active Instructional Media ........ 47

Table 12 High Use of IM Across All Years by Grade Level $\quad \ldots . \ldots \ldots \ldots \ldots \ldots \ldots \ldots . . . . .49$

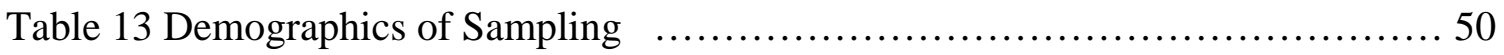

Table 14 Bloom’s Taxonomy and Association of Instructional Strategy and

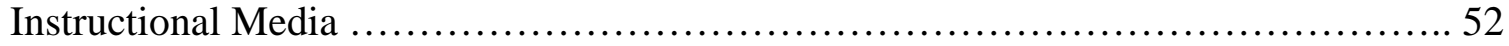

Table 15 Bloom’s Taxonomy: Customized .................................... 53

Table 16 IM and Numerical Rank Based on Bloom’s Customized Taxonomy .............. 55

Table 17 Instructional Media, Total Number of Times Used, and Mode:

Bloom’s Rank ...........................................................56

Table 18 Bloom's and Tomei’s Taxonomies with Instructional Strategies and

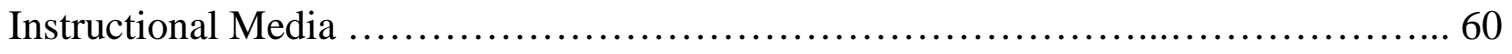

Table 19 Tomei’s Instructional Technology Taxonomy: Customized ................... 61 
Table 20 IM and Numerical Value According to Tomei’s Instructional Technology

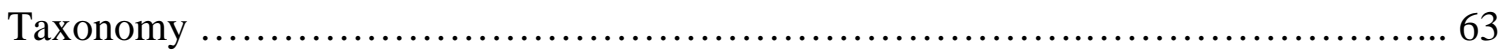

Table 21 IM and Level of Integration on Bloom’s and Tomei's Taxonomies ........... 64

Table 22 Instructional Media, Total Number of Times Used, and Mode: Tomei Rank... 65

Table 23 Integration of Instructional Media and Most Frequently Added Level on

Taxonomies .............................................................. 66

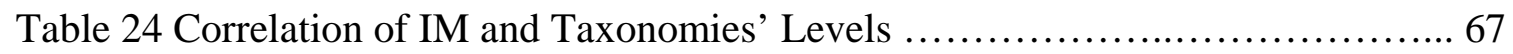

Table 25 Classification of IM According to Most Frequently Associated Level of

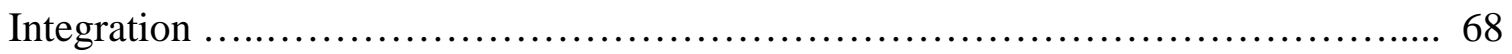

Table 26 Key Words Common to Multiple Interview Responses .................... 71

Table 27 Alignment of Research Questions to Interview Questions .................. 72

Table 28 Summary of Quantitative and Qualitative Data Analysis .................... 79 


\section{List of Figures}

Figure 1 Stages of Quantitative and Qualitative Analysis ....................... 41 


\section{Chapter 1}

Introduction

Technology is evolving rapidly. Many teachers are required by their state to integrate technology into the classroom. Some teachers lack the skills and training to use technology themselves and are unsure as to how to integrate it into the curriculum. Others are using the computer as a multimedia desktop presentation system, a delivery system, and as a research tool. Kristof and Satran (1995) stated that computers today are far more interactive than they once were because of their use for tasks that were once considered not to be interactive-reading, watching, or used as entertainment. While technologies have evolved rapidly and some teachers have appeared to adapt to their use, there is some concern that many teachers have not been trained to use technology effectively (McCombs, 2000).

Traditionally, technologies available to classroom teachers included slides, tape, video, and multi-image presentation equipment (Jonassen, Peck, \& Wilson, 1999). These media have evolved and are now available digitally. Today’s classroom instructor has added the computer to the list of tools available as instructional media. "The multimedia desktop computer. . . is now able to capture, synthesize, and manipulate sounds, video, and special effects. . . and integrate them all into a single multimedia presentation” (Jonassen, et al., p. 87). The evolution of classroom technologies has happened so rapidly that researchers are still defining terms.

Historically and artistically speaking, mixed media referred to an artwork that was completed using more than one medium. Some artists used the term multi-media (Ungar, 1985) meaning that a work was created using multiple media or more specifically, the 
work was created using a variety of materials (Wilkins, Schultz, \& Linduff, 1994).

Multimedia today (formerly, and still used by many, multi-media) has been redefined for the digital age. While most current authors agree that multimedia is defined as a combination of several types of media (Merrill, Hammons, Vincent, Reynolds, Christensen, \& Tolman, 1996), references to multi-media are generally in the context of screen-based media, not print-based media (Heller \& Drennan, 1997). In the artistic sense, multi-media in a digitally based environment evolved to multimedia, and then to new media (Heller \& Drennan). In an educational context, audiovisual education changed to instructional communication, then became educational media or instructional media, and is now referred to as instructional technology (Counts, 2004). For the purpose of this study, instructional technologies refers to the multiple media that are utilized in a learning environment.

According to Alessi and Trollip (2001) multiple studies have been completed in order to prove that technologies, computer associated technologies in particular, improve learning more than traditional classroom instruction. The authors noted that overall, the studies showed little success with learning and computer associated technologies. McCombs (2000) stated that although researchers agreed that when properly applied, instructional technologies can enhance learning, schools are trying to cope with state mandates and the integration of technologies, and learning is still at the lower levels of cognitive thinking. Since learning depends on the way the technologies are used and not the technologies themselves (Bitter \& Pierson, 2002), teachers must design lessons that integrate technologies into the learning environment. Lessons, therefore, need to be designed in such a way as to exploit available instructional technologies. 
Traditionally, students learned about computers; now students learn with computers (Jonassen, 2000). Use of the computer, however, has advantages and disadvantages. Some of the advantages, according to Lee and Owens (2000) include consistent delivery of information, accommodation to an individual's time schedule, learner control of the pace of instruction, and an unlimited opportunity for review of the information. Lack of immediate feedback specific to content and outdated information are examples of the limitations of computer-based instruction according to the authors. However, the learner, by nature of the task, is interacting with the computer when it is used as a desktop presentation system (Kristof \& Satran, 1995). Many of the limitations of computer-based instruction, such as communication, for example, can be overcome when utilizing the Web as a mode for the delivery of instruction. Web-based communication programs include e-mail, bulletin boards, chat rooms, and webinars (web-based seminars) to name a few. The computer can be used to supplement course content. Course information such as assignments, projects, and updated material can be easily posted to a course web site (Lee \& Owens, 2000).

Whether used as a research tool or in collaborative projects, web-based instruction and communication can elicit meaningful learning (Driscoll, 1998). Harris (1998a) stated that teachers who incorporate the Internet into the classroom generally use the Internet as a tool, to find and create information either as a group or as an individual working on a project. She noted that tools were not as important as how the tools were used or applied. Harris offered a set of telecollaborative activity structures that she referred to as "wetware tools." These tools are thinking tools that are both flexible and customizable and can be used by teachers in the design process for web-based instruction. Harris 
stressed the need for instructional strategies along with an understanding of the capabilities of instructional technologies.

What Harris (1998a) referred to as thinking tools are types of instructional technologies. She has successfully couched instructional technologies into a telecollaborative framework and instructional strategies. Jonassen (2000) on the other hand, referred to instructional technologies as mindtools; computer-based tools and environments that engage the learner and promote higher order thinking. He commented that higher order thinking and knowledge construction is hard to assess and suggested rubrics for evaluating learning. Both Harris (1998a) and other experts such as Clark and Mayer (2003) recognized the interdependent relationship of instructional technologies and the learning process. Laurillard (2002) called attention to the fact that instructional technologies do not easily lend themselves to classification. The authors agree that while all instructional technologies are not created equal (Clark \& Mayer), when placed within a theoretical framework that promotes active learning, instructional technologies have the capability of promoting higher levels of thinking (Clark \& Mayer; Jonassen). This is especially relevant when used in authentic or real-world learning (Alessi \& Trollip, 2001; Keirns, 1999; Laurillard).

Need for the Study

Research shows that web-based instruction, although still evolving, has the ability to not only engage learners in topics that are important to them (Driscoll, 1998) but to do so in real-world tasks (Jones, Harmon, \& Lowther, 2002; Fetherston, 2001). This type of authentic learning has the potential to promote higher order thinking provided students are properly skilled in the use of instructional technologies and confident in the use of the 
web (Fetherston). Cunningham and Billingsley (2003) noted that there is a lack of good research regarding technology integration, and because of the lack of equal access at home there is a strong argument for the use of technology at school. This study, which analyzes the use of instructional technologies in a web-based learning environment, will add to the body of knowledge concerning the use of instructional technologies and webbased instruction in grades pre-K through 12 (P-12) by demonstrating a correlation between the types and use of instructional technologies and cognitive levels of learning. Purpose of the Study

It is the purpose of this study to analyze multiple media as instructional technologies used to enhance interactivity in a web-based environment and to illustrate the potential for improved learning through the use of interactive multiple media.

\section{Research Questions}

Specifically, this study will investigate

1. What types of instructional media do P-12 teachers integrate into web-based learning?

2. In what way is the instructional media used?

3. What is the level of student engagement with the instructional media?

4. What level of learning did the instructional media address?

5. Is there a correlation between types and use of instructional media and cognitive levels of learning? 


\section{Limitations}

The participants in this study consist of pre-K through 12 (P-12) teachers who attended summer institutes (Trek 21) at West Virginia University. The project covered three years and included participants who attended for multiple years. The Trek 21 Institute involved participants from schools that met certain criteria in order to be eligible to participate in the program. This study is centered on instructional technologies that were the focus of the Institute, therefore, not all instructional technologies are assessed. However, the strategies that emerged may provide some guidance for those interested in integrating instructional media and web-based instruction into P-12 educational settings. Overview of Methodology

This study involved the use of extant data gathered by project evaluators of the Trek 21 Institute. In-depth analysis, although based on the extant data, involved examining new data by studying a purposeful sampling of the participants involved with the three-year project. This study focused on four areas of web-based instruction in a P12 environment: 1) type of instructional technology, 2) how the instructional technology was used, 3) level of learning that the instructional technology addressed, and 4) it examined a possible correlation between types and use of instructional technologies and cognitive levels of learning. For the purpose of this research, the specific media studied as instructional technologies were those that were utilized during the Trek 21 project. Project evaluators designed an evaluation instrument, The Indicators of Instructional Change Instrument-Random Comprehensive Evaluation-Pre-and Post-Implementation (IICI) (Appendix A), to assess the web-based units completed by Trek 21 participants. A component of the instrument included information associated with instructional technologies specific to Trek 21. 
The Indicators of Instructional Change Instrument (Mitchem \& Wells, 2002) designed by external evaluators of the Trek 21 project are discussed in detail in Chapter 3. Briefly, the external evaluators designed and used the instrument (Appendix A) to analyze the effective integration of instructional technologies for the Trek 21 project. Results from their analysis were used to address the first research question in this study. The first research question, What types of instructional media do P-12 teachers integrate into web-based learning?, will be answered using this evaluation instrument since the IICI was designed based on instructional technologies specific to Trek 21. A select number of lessons from this group will be used to answer the second research question, In what ways are the instructional media used? What is the level of student engagement with the instructional media?, the third research question, will be summarized using the results of the Trek 21 Evaluation Report and Analyses for K-12 Participants Institute Years 1-3, (Mitchem \& Wells, 2002). In this report, the authors indicated that active student engagement occurred when the learner provided an obvert response, such as retrieving information from the Web, when provided with an instructional cue. They discussed additional examples, along with the coding of information. Results of the Mitchem and Wells study were based on the total number of participants of the three years of the Institute. The analysis of the participants' units from the IICI was used to extract a percentage of the participants for an in-depth sampling for this study.

The use of instructional media and the cognitive level of learning activities, research question four, was addressed using Bloom’s et al. (1956) Taxonomy for Educational Objectives (Appendix B). A numerical value associated with each example of cognitive learning was ranked according to the levels of learning associated with 
Bloom's taxonomy. The level of intellectual activity associated with instructional technology, research question five, was evaluated using Tomei’s (2001) Taxonomy for Instructional Technology (Appendix C). This taxonomy includes progressive levels of technology integration "from simple to complex, first to last, general to specific" (Tomei, ND, par. 5). Selected instructional technologies were ranked with both taxonomies and further analyzed to determine if a correlation exists between the types and use of instructional technologies and the cognitive levels of learning.

To provide a more in-depth look at the integration of instructional media, individuals whose units indicated a high use of instructional media based on the analysis conducted by external evaluators, were selected for an interview. The researcher worked closely with the participants and Trek 21 , and when contacted, readily agreed to an interview. Some of the participants, because of their familiarity with the researcher, might have been reluctant to discuss any difficulties associated with the integration of their unit, which would be a limitation. However, because of the knowledge and experience that the researcher had with the participants and their units, she was able to illicit responses specific to Trek 21 and the units. In addition, when a participant was unfamiliar with a specific term, such as activity structures, the researcher was able to define the term to the participant in the context of Trek 21.

Because of the purposeful selection of designers who showed a high use of instructional technologies, a pattern emerged that supports a correlation between the types and use of instructional media with the cognitive levels of learning. As the results indicated that a correlation exists, then research would show that there is the potential for improved learning through the use of interactive multiple media and indicated which 
instructional technologies would be more apt to promote higher order thinking. Teachers would now have a framework for designing instruction which integrates the use of instructional media that encourages active student engagement and higher levels of learning.

A review of literature is found in Chapter 2. Details pertaining to the methodology related to this study are discussed in Chapter 3. Evaluation instruments used to analyze the lesson plans and graphical displays of results are included in appendices. The results generated from quantitative and qualitative data analysis are discussed in Chapter 4. Discussions based on the study's findings and conclusions are in Chapter 5 with recommendations for further research. 


\section{Definition of Key Terms}

Activity structures - a flexible framework of activities that integrate the Internet and is customizable to the individual needs of different people (Harris, 1998a).

Asynchronous learning - a group shares a learning experience but not in real time (Driscoll, 1998).

Formative evaluation - evaluation done during the development or design phase that may lead to modification in the design (Dick, Carey, \& Carey, 2001; Elin, 2001).

Instructional design - an "academic discipline that designs instructional programs and systems suitable for the learners, the subject matter, and the learning environment” (Elin, 2001, p. 344).

Interaction - "behaviors by which individuals or groups influence each other” (Dempsey \& Van Eck, 2002, p. 286)

Interactive Multimedia - involves an exchange between the user and the media as well as the use of multiple medium (Misovich, Katrichis, Demers, \& Sanders, 2003).

Internet - “a world-wide network that connects many smaller networks” (Roblyer \& Edwards, 2000, p. 333). MOO/MUD - 3D graphical worlds; object-oriented multi-user domain (Preece, Rogers, Sharp, 2002).

Multimedia - a combination of several types of media (Merrill, et al., 1996). Examples of multimedia include audio, video, text, graphics and animation (Driscoll, 1998); referred to as instructional technologies in this study.

Summative evaluation - evaluation completed after the design and implementation phase that determines the effectiveness of a product or program (Dick, et al., 2001; Elin, 2001). 
Synchronous learning - learning strategies that take place in real-time (Driscoll, 1998).

Telecollaboration - "educational applications for Internetworked tools as either collaboration with distant colleagues or research using, at least in part, resources located elsewhere” (Harris, 1998, p. 17).

World Wide Web - "on the Internet, a system that connects sites through hypertext links" (Roblyer \& Edwards, 2000, p. 337). 


\section{Chapter II}

Review of Literature

In our current age many baby boomers, products of the 1950s, are teachers at a time when technology has jumped from pencil and paper to Personal Digital Assistants (PDAs) and laptop computers. As new technologies are introduced into classrooms, teaching strategies in how to integrate them are explored. This chapter discusses media as activity structures, interactive media, and taxonomies that illustrate activities associated with cognitive thinking, educational objectives, and instructional technologies. This section concludes with the theoretical frameworks of selected research associated with Trek 21.

\section{Media as Instructional Technologies}

The impact that technology has had on learning is undeniable, especially if one considers the rapid change in computer technology. Computers are considered to be synonymous with technology in the classroom, and in this study the computer is the focal point of the media and technologies discussed. Lee and Owens (2000) described three broad areas for classroom technologies: 1) computer-based technologies, 2) web-based technologies, and 3) distance broadcasting. Technologies in the third area, distance broadcasting, are beyond the scope of this study and are not included in this discussion.

Computer-based technologies include all software programs from word processing and databases to computer-based simulations. Jonassen (2000) viewed computer-based technologies as mindtools that engage learners and foster critical thinking. In additional to mathematical programs such as spreadsheets and databases used for calculating, he added visualization tools for mindmapping and multimedia tools for 
publishing. The later category included authoring programs with a convergence of computer- and web-based programs. Jonassen referred to these technologies as mindtools because they help to extend limits of the mind.

Web-based technologies are those that involve the Internet and include all computer-based technologies as well as web-based communication. Web-based communication includes email, chat, threaded discussions, and listservs (Brunner \& Tally, 1999). Judi Harris (1998a) referred to her instructional technologies as "wetware" tools and suggested eighteen activity structures within three genres (Table 1) for their incorporation into the classroom.

Table 1

Judi Harris’ Genres and Telecomputing Activities

\begin{tabular}{|c|c|c|}
\hline Interpersonal Exchange & $\begin{array}{c}\text { Information Collection } \\
\text { and Analysis } \\
\end{array}$ & Problem Solving \\
\hline - keypals & - information exchanges & - information searches \\
\hline - global classrooms & - database creation & - peer feedback activities \\
\hline •electronic appearances & - electronic publishing & • parallel problem solving \\
\hline - telementoring & - telefieldtrips & - sequential problem solving \\
\hline $\begin{array}{l}\text { - question-and-answer } \\
\text { activities }\end{array}$ & - pooled data analysis & - telepresent problem solving \\
\hline \multirow[t]{2}{*}{ - impersonations } & & - simulations \\
\hline & & - social action projects \\
\hline
\end{tabular}

Note: From Harris, J. (1998). Virtual Architecture: Designing and Directing CurriculumBased Telecomputing. Adapted with permission. 
According to Harris, designers who use these eighteen activity structures should consider two questions:

1) Will this use of the Internet enable students to do something they couldn't do before?

2) Will this use of the Internet enable students to do something they could do before, but better? (p. 9)

If the answer is “no," there is no need to integrate the Internet as part of the learning. Jonassen (2000) and Harris, as do most designers, see instructional technologies as tools that have the capacity to extend learning. Multimedia

Making multimedia requires a higher-level of thinking than using multimedia (Mitchell, 2003). Mitchell characterized the creation of multimedia as being similar to the work of artists. During the creating process, students explore and synthesize, are more engaged, and therefore take an active part in learning. Mitchell equates the process to an academic studio. He concluded that students who use media technologies to create products engage in higher order thinking. His rationale was based on the work of Mayer (2001) who has explored the multimedia learning theory in depth for the past ten years. Mayer noted two primary approaches to multimedia learning: multimedia is either technology-centered or it is learner-centered. He explained that technology-centered focuses on using "cutting edge” technology in presentations for example. Learnercentered multimedia, however, focuses on how multimedia can be used to enhance learning. The "create" component is a key element of multimedia learning and a crucial component of interactive multimedia according to Mayer. 


\section{Interactive Media}

Interactive media not only involves multimedia but also requires an exchange between the learner and the media (Misovich, et al., 2003). Multimedia technologies, according to the Misovich, et al., are generally computer-based and include tools used to create digital presentations, animations, and videos. Interactivity occurs when the student is engaged in an active and reflective way with the media, that is, the student makes a choice after being presented with a problem. According to Laurillard and Taylor (1994), interactivity supports complex learning and engages students. Jonassen (2000) discussed an instructional technology known as a microworld where students explore learning environments. Although considered by many to be analogous with simulations, Laurillard (2002) explained that students build their own microworlds whereas someone else creates a simulation that the student then explores. Microworlds have the ability to engage learners in higher order thinking (Jonassen; Laurillard) in that students construct knowledge based on basic, critical, and creative thinking (Jonassen). Although Stoney and Oliver (1999) stated that multimedia, because of its linear nature, has failed to make a significant difference in learning, they view multimedia microworlds, where students plan and control their own learning, as contributing greatly to higher order thinking and problem solving skills of learners.

Many instructional designers have supported the use of instructional media for learning, and a few have offered a framework for their integration into the learning environment. The four examples in Table 2 are reflective of others in the field, although Fetherston's (2001) is web-specific. Common traits from the illustrated frameworks 
(collaborative, reflective, and authentic) are all characteristic of higher order thinking (HOT).

Table 2

Frameworks for Instructional Media Integration

\begin{tabular}{|c|c|c|c|}
\hline $\begin{array}{c}\text { Kearsley \& } \\
\text { Shneiderman }\end{array}$ & Fetherston & Jonassen & Laurillard \\
\hline $\begin{array}{l}\text { - Collaborative } \\
\text { - Creative } \\
\text { (reflective) } \\
\text { - Authentic }\end{array}$ & $\begin{array}{l}\text { - Collaborative } \\
\text { - Authentic }\end{array}$ & $\begin{array}{l}\text { - Active } \\
\text { - Constructive/reflective } \\
\text { - Intentional } \\
\text { - Authentic } \\
\text { - Cooperative/collaborative }\end{array}$ & $\begin{array}{l}\text { - Authentic } \\
\text { - Reflective }\end{array}$ \\
\hline
\end{tabular}

Bullock and Ory (2000) commented on a "megastudy" (a study of studies) conducted by Thomas Russell in 1999, No Significant Difference Phenomenon, on the integration of instructional technologies. Of importance to this paper is that in the 355 studies reviewed, the authors concluded that there was no single approach or model that rose above any other regarding the use and integration of instructional technologies. In light of the rapid pace of innovative advances in technology in recent years, it is not surprising that there is no "one best way.” It is possible that a single model has not been developed due to the rapid pace of advances in technology.

\section{Taxonomies}

Laurillard (2002) classified media according to the learning experiences associated with its use and commented that media are not easily classified. A few years earlier, Bruce and Levin (1997) noted that media could fit more than one category depending on its use. They designed a taxonomy for the integration of media into the learning environment. Bruce and Levin stated that they preferred the term media instead of technology, tool, program, or application because those terms seem to focus on the 
hardware or software and not on the user or learner. They proposed that media be classified according to its use and based their proposal on the four categories that Dewey (1943) suggested several years earlier: inquiry, communication, construction, and expression. They believed that Dewey's categories were broad enough to include all technologies centered around the computer. The authors saw their taxonomy of media as a work in progress and acknowledged that other frameworks existed based on content, grade level, hardware, software or function. Laurillard's taxonomy was broader than the computer-centered taxonomy designed by Bruce and Levin since it included multiple mediums: print, video, and online conferences.

Bloom's Taxonomy of Educational Objectives. One of the best known and applied taxonomies in education is the Taxonomy for Educational Objectives (Appendix B) developed by Bloom (1956) and his colleagues. This taxonomy was developed as a theoretical framework for examiners while testing. The framework was designed as a way to assess testing effectiveness (Bloom, et al.). The developers also hoped that teachers would find the taxonomy helpful for the analysis of educational outcomes. The original plan was to develop a taxonomy that included three domains of learning: cognitive, affective, and psychomotor. Because most learning takes place in the cognitive domain, that part of the taxonomy was developed first. Bloom categorized cognitive learning in a hierarchy: knowledge (low level cognitive learning), comprehension, application, analysis, synthesis, and evaluation (high level of cognitive learning). Verbs related to learning objectives help teachers identify activities associated with levels of learning (Appendix B). For instance, given a list of examples, categorize hard woods versus soft woods, would be at the second cognitive level (comprehension) according to 
the taxonomy. Bloom justified the hierarchal order based on the assumption that lower level simple behaviors would be combined or integrated in higher levels. The taxonomy was intended to be used as a guide so that learners were encouraged to move up through the levels (Bloom).

Bloom (1956) intended that other taxonomies specific to other genres be developed. Anderson, Krathwohl, Airasian, Cruikshank, Mayer, Pintrich, Raths, and Wittrock (2001) introduced additional taxonomies and alternative frameworks, based on Bloom's original taxonomy in A Taxonomy for Learning, Teaching, and Assessing: A Revision of Bloom's Taxonomy of Educational Objectives, Complete Edition. Krathwohl, co-author, was also a member of the group who worked on what is now commonly referred to as Bloom's taxonomy. Suggestions or contributions were sought from several members of the original group, including Bloom, for Krathwohl’s, et al., book.

Tomei’s Technology Taxonomy. Lawrence Tomei (2001) developed a taxonomy of instructional technology based on Bloom’s (1956) taxonomy. Tomei’s (Appendix C) taxonomy consists of six interconnected levels that vary in complexity, from low to high: literacy, communication, decision-making, instruction, integration, and acculturation. For example, using web-based search engines is classified as communication when students work collaboratively and share ideas, level three of Tomei’s taxonomy. Many of the verbs used in Bloom’s taxonomy are also used in Tomei’s taxonomy (Table 3). 


\section{Table 3}

Bloom's and Tomei’s Taxonomies: Comparison of Action Verbs

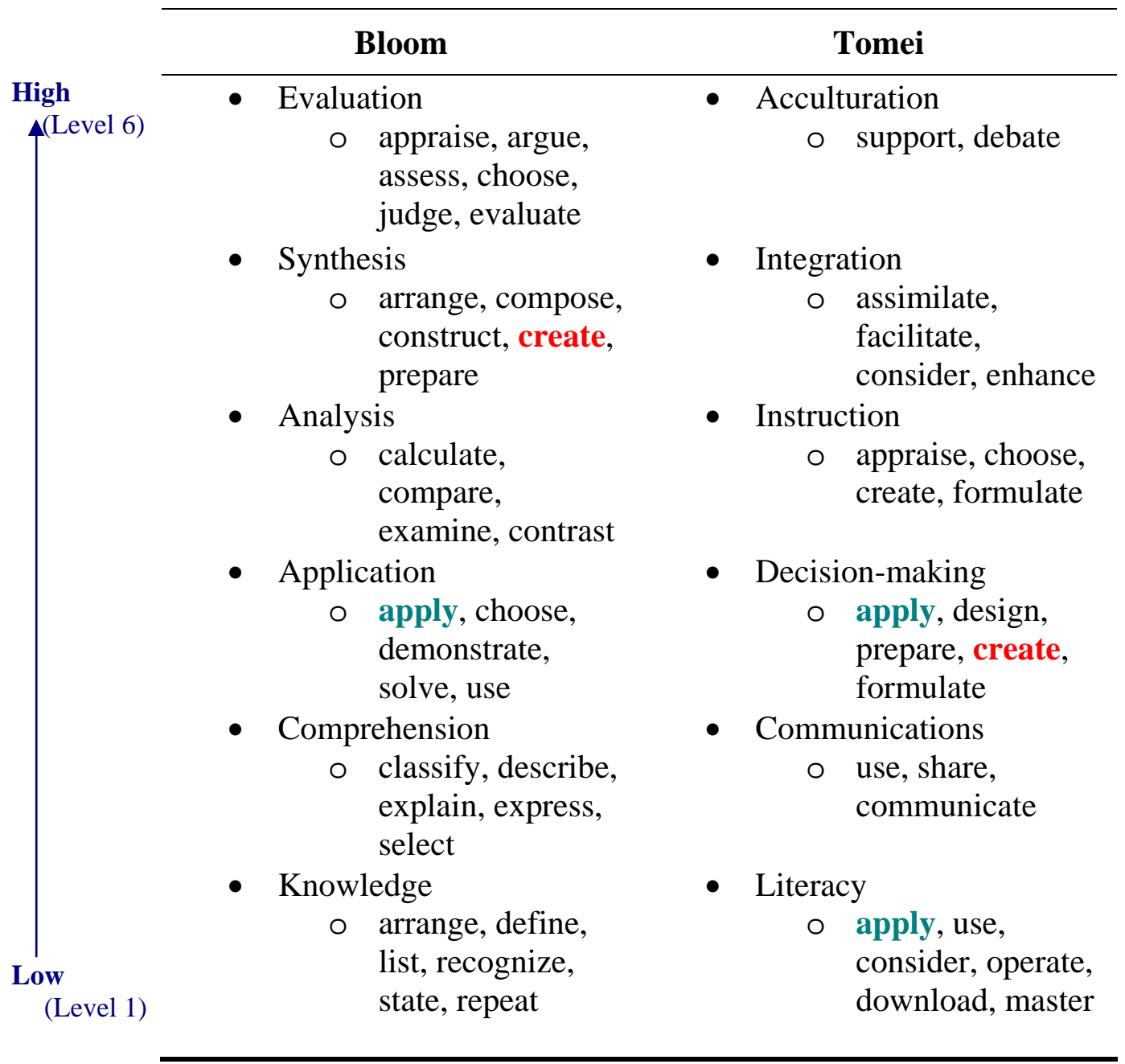

Within a single lesson a teacher may address multiple levels of both Bloom’s \&

Tomei’s taxonomies when the assigned activity includes the integration of technology.

When students use the information gathered with the use of web-based search engines to restate material in their own words and to construct meaning, the activity ranks on level three on Tomei's taxonomy (decision-making) and level two (comprehension) on Bloom’s (Appendix B) taxonomy. The use of the Internet in the above example is 
centered around a learning activity and not technology; technology is a tool. When a student constructs meaning in this way, deep learning takes place (Fetherston, 2001).

The frameworks outlined in Table 2 have common traits to Bloom's and Tomei's taxonomies. For example, “collaborative” is common to Kearsley and Shneiderman (1999), Fetherston (2001), and to Jonassen (2000). Collaboration is also a part of the affective domain which is closely associated with Bloom's taxonomy of the cognitive domain (Krathwohl, Bloom, Masia, 1967). Collaboration is addressed by Tomei (2002) through actions for learning that students exhibit in response to instructional, humanistic objectives. These actions may represent level two on his taxonomy, where students communicate and share information, to level six, the highest level of cognitive learning, where students debate or present a topic. Active learning, a result of authentic tasks, (Fetherston, 2001; Jonassen, 2000; Kearsley \& Shneiderman, 1999; Mitchell, 2003; Laurillard, 2002) is another common element of the frameworks for instructional media integration discussed earlier (Table 2). Active learning is achieved on one level when a learner is engaged with the content or at a higher level when a learner interacts with the content, which has the potential to raise a learner's cognitive learning level (Fetherston). Multimedia Learning and the Taxonomies

Learners gain knowledge better when the content is presented as multimedia where pictures and text are both used, as opposed to when the content is presented as text only or as pictures only (Mayer, 2001). Although Mayer does not address creativity directly, embedded within his criteria for the cognitive theory of multimedia learning for learner-centered multimedia environments is applicability where the principles of multimedia learning can be applied to new learning situations. Mayer's theory of 
multimedia learning combined with Bloom’s (1956) Taxonomy of Educational Objectives and Tomei’s (2001) Instructional Technology Taxonomy illustrates the possibility of what type of learning could occur when a learner uses instructional technologies in response to a problem-solving activity by ranking high on both taxonomies. Laurillard (2002), however, stated that instructional technologies do not lend themselves to pedagogical classification. She classified ITs based on dialogue forms (Table 4) which takes into consideration the interdependent relations that the technologies have with all aspects of the learning process (Laurillard).

Table 4

Five Media Forms, Learning Experiences, and Methods

\begin{tabular}{|c|c|c|}
\hline Learning experience & Methods/technologies & Media forms \\
\hline $\begin{array}{l}\text { Attending, } \\
\text { apprehending }\end{array}$ & $\begin{array}{l}\text { Print, TV, video, } \\
\text { DVD }\end{array}$ & - Narrative \\
\hline $\begin{array}{l}\text { - Investigating, } \\
\text { exploring }\end{array}$ & $\begin{array}{l}\text { - Library, CD, DVD, } \\
\text { Web resources }\end{array}$ & - Interactive \\
\hline - Discussing, debating & $\begin{array}{l}\text { - Seminar, online } \\
\text { conference }\end{array}$ & - Communicative \\
\hline $\begin{array}{l}\text { - Experimenting, } \\
\text { practicing }\end{array}$ & $\begin{array}{l}\text { - Laboratory, field } \\
\text { trip, simulation }\end{array}$ & - Adaptive \\
\hline $\begin{array}{l}\text { - Articulating, } \\
\text { expressing }\end{array}$ & $\begin{array}{l}\text { - Essay, product, } \\
\text { animation, model }\end{array}$ & - Productive \\
\hline
\end{tabular}

Note: From Laurillard (2002), Rethinking University Teaching: A Conversational Framework for the Effective Use of Learning Technologies. Reprinted with permission.

Application of a concept and creativity rank high on both Bloom's (Appendix B) and Tomei's (Appendix C) taxonomies. Using the technology as an operation is less complex and not as long-term as using the technology as an application (Harris, 1998a). Therefore, an activity that requires a learner to apply a concept using technologies has the potential of effecting long term, higher order thinking levels of students. 


\section{Taxonomies and Trek 21}

Bloom’s (Appendix B) and Tomei’s (Appendix C) taxonomies were introduced to the participants at the beginning of each Trek 21 Institute. The taxonomies were used as tools to assist the participants in reflecting on their teaching practices and as guidelines during the creation of their web-based instructional units. At the beginning of each Institute examples of Harris’ (1998a) educational telecollaboration activities were explained; these were discussed earlier in this chapter. Participants were asked to integrate one telecollaborative activity into their unit in order to enhance teaching and learning.

Several unpublished and published reports about the Trek 21 Institute are available from the Trek 21 site (www.trek-21.wvu.edu). Many of the reports concern the first year or the first and second year of the Institute. Theoretical frameworks of these reports include change in teacher practice, effective integration of instructional technologies, choice of instructional technologies, teachers’ designs of engaging learning environments, building toward higher levels of technology integration, and PT3 grant dissemination efforts. This research paper, while utilizing some of the data previously mentioned, goes more in-depth by including data from all three years of the Institute and by including current qualitative data from selected participants of each of the three years. Because this data expands over and beyond the years of the Institute, insights such as instructional technologies in current use and teachers’ perceived results of web-based units will illustrate the sustaining goals of Trek 21: to prepare teachers as agents of technological change, and give them the knowledge and skills to integrate instructional technologies into the learning environment. 


\section{Summary}

This chapter has reviewed the literature related to this study: media as instructional technologies, activity structures, interactive media, education and technology taxonomies, the relationship between multimedia learning and the taxonomies, and the taxonomies and Trek-21. The review of literature illustrated the potential of instructional technologies. When used in conjunction with authentic tasks where students are engaged in a reflective way as a result of the interactivity with the content, a higher level of learning occurs. Finally, the review highlighted the taxonomies and activity structures addressed at the beginning of each Trek 21 Institute that participants were encouraged to integrate into their web-based units, and noted the theoretical framework of selected unpublished and published reports about Trek 21. 


\section{Chapter III}

\section{Methods}

Specific methodology and data gathering instruments were used to analyze multiple instructional technologies used to enhance interactivity in a web-based learning environment. These are described below with study participants, design of the study, and procedures. A discussion of the researcher's role concludes the methodology.

\section{Participants}

The participants in this study were comprised of 107 pre-K through 12 (P-12) teachers from five counties in northern West Virginia who attended one or more Trek 21 summer institutes at West Virginia University during 2000-2002. The Trek 21 project was a U.S. Department of Education Preparing Tomorrow’s Teachers to Use Technology (PT3) implementation grant, and involved twenty-one professional development public schools associated with the Benedum Collaborative and West Virginia University (Wells, 1999). Trek 21 was designed to prepare teachers as agents of technological change by giving them the knowledge and skills to integrate instructional technologies into the learning environment (Wells, 1999). Each Trek 21 summer institute was held for three weeks for three consecutive years beginning in 2000 .

Table 5 summarizes the demographics of Trek 21 participants. The table represents a stratified overview of the Institute's years representing each of the three years by participant’s gender, grade level, subject area (general or special education), and the number of participants who attended more than one institute (cycle count). Over the three years, there were 101 female participants and 6 male participants for a total of 107 participants. Grade levels represented by the teachers during the three years included two 
preschool, 71 elementary, 15 middle school, and 19 high school teachers. Of the 107 participants, 99 taught general education subjects and 8 taught special education subjects. During Year 2 there were three people who had participated in Trek 21 the summer of Year 1. During Year 3, there was one person who had participated in Trek 21 the previous two summers, and 12 people who participated in Trek 21 either the first or the second summer it was offered.

Table 5

P-12 Participant Demographics Years 1 - 3

\begin{tabular}{|c|c|c|c|c|}
\hline Institute Year & Gender & Grade Level & General/ Special & $\begin{array}{l}\text { Participant } \\
\text { Cycle Count }\end{array}$ \\
\hline Year 1 & $\begin{array}{l}41 \text { Female } \\
4 \text { Male } \\
\mathrm{N}=45\end{array}$ & $\begin{array}{l}0 \text { Preschool } \\
29 \text { Elem } \\
5 \text { Middle } \\
11 \text { High }\end{array}$ & $\begin{array}{l}43 \text { General } \\
2 \text { Special }\end{array}$ & 1st Cycle 45 \\
\hline Year 2 & $\begin{array}{l}25 \text { Female } \\
2 \text { Male } \\
\mathrm{N}=27\end{array}$ & $\begin{array}{l}2 \text { Preschool } \\
17 \text { Elem } \\
4 \text { Middle } \\
4 \text { High }\end{array}$ & $\begin{array}{l}24 \text { General } \\
3 \text { Special }\end{array}$ & $\begin{array}{l}\text { 1st Cycle } 24 \\
\text { 2nd Cycle } 3\end{array}$ \\
\hline Year 3 & $\begin{array}{c}35 \text { Female } \\
0 \text { Male } \\
\mathrm{N}=35\end{array}$ & $\begin{array}{l}0 \text { Preschool } \\
25 \text { Elem } \\
6 \text { Middle } \\
4 \text { High }\end{array}$ & $\begin{array}{l}32 \text { General } \\
3 \text { Special }\end{array}$ & $\begin{array}{l}\text { 1st Cycle } 22 \\
\text { 2nd Cycle } 12 \\
\text { 3rd Cycle } 1\end{array}$ \\
\hline
\end{tabular}

Note: From Mitchem, K., \& Wells, D. (2002). Trek 21 Evaluation Report Lesson Sweep Analyses for K-12 Participants Institute Years 1-3, unpublished report. Reprinted with permission.

Participants were provided with a laptop, software, instruction in pedagogy, and training in various software programs. Each participant was asked to prepare five lesson 
plans prior to attending Trek 21 that they would augment during the Institute with instructional technologies, including a minimum of one telecollaborative activity based on Judi Harris' (1998a) telecollaborative genres. The five lesson plans that the participants prepared for the Trek 21 institute served as the basis for instructional technology (IT) integration into a web-based instructional unit. As part of Trek 21, the participants took part in two continuity meetings, one each semester following the summer institute that they attended. During the continuity meetings, participants had the opportunity to adjust or revise their web-based instructional unit developed during the institute.

\section{Design and Instrumentation}

This study includes information from extant data completed by Trek 21 project evaluators, instructional leaders, graduate assistants, and the project director over a threeyear period (2000-2003). Conference papers, presentations, and associated links are available through the Trek 21 web site (www.trek-21.wvu.edu). Of particular importance to this study was a measurement instrument designed by project evaluators, Mitchem and Wells (2001). The Indicators of Instructional Change Instrument—Random Lesson Sweep and Comprehensive Evaluation (IICI) (Appendix A) was designed to specifically assess instructional change in web-based instructional units developed by Trek 21 participants. Since the IICI was principally designed from material in the web-based units from the Trek 21 institute, its use is central to this study in that its use is associated with the first three research question of this study. Details about the instrument follow.

The Indicators of Instructional Change Instrument-Random Lesson Sweep and Comprehensive Evaluation. The 37-item IICI (Appendix A) was designed to compare 
lesson plans participants submitted prior to attending the summer institute to their webbased instructional unit at the conclusion of the Trek 21 institute. According to Mitchem, et al. (2002) the instrument was piloted and its content and use subjected to expert review with suggestions integrated into the final instrument.

The instrument assessed three categories associated with instruction: instructional procedures, instructional strategies, and instructional technologies. Instructional procedures included seven items which were based on a literature review of effective instruction: motivating introduction, check for prerequisite skills, present new content, guided practice, independent practice, closure, and extensions or additional activities (Mitchem, et al., 2002).

The thirteen items identified instructional strategies on the IICI (Appendix A) included: advance organizer, whole group instruction, peer-mediated instruction, group discussion, active responding, problem solving, research, inquiry, hands-on manipulative, dramatic representation, journaling/writing, student presentation, and teacher demonstration. Although not a comprehensive list of instructional strategies according to Mitchem, et al. (2002), these strategies were present in the participants' web-based instructional units. The thirteen items listed on the IICI for instructional technologies were based on those represented in the participants' web-based instructional units. These items included computer-aided instruction/drill and practice, simulation/educational games, word processing, information retrieval, Internet access, email, bulletin boards/Listservs, authoring/multimedia development, desktop publishing, electronic presentations, video development, open lab development, and web page development (Mitchem, et al.). 
Project evaluators, using the IICI, also indicated components that encouraged active student engagement in the previously mentioned categories. Examples of active student engagement included information retrieval from a web site, discussion participation, a written or verbal response to an assignment, or sequencing cards. Examples of passive student response included listening, reading, and observing a PowerPoint presentation or web site (Mitchem, et al., 2002). Coding was used to illustrate whether or not each component encouraged active student engagement. Data recorded on the IICI were a result of a random sweep analysis that involved recording information from one lesson, selected at random, from each of the web-based units prepared by Trek 21 participants for a total of 107 lessons.

According to Mitchem and Wells (2002), the ICCI (Appendix A) was initially used by each project evaluator to independently assess one lesson from each unit (random lesson sweep) and then to assess all lessons (five) in the unit (comprehensive lesson sweep). Sampling and data were identical from both the random and the comprehensive sweep, thus evaluators deemed a random lesson sweep was representative of each participant's unit. During the evaluation, units were stratified (preschool, elementary, middle school, and high school) to ensure representation across grade levels. Any rating disagreements were discussed and resolved by the evaluators. Scores obtained during the lesson sweeps were entered into a statistical software program for analysis (Mitchem \& Wells).

Background information regarding the Trek 21 participants, such as curriculum area and grade, was also recorded on the IICI. Extant data from the Mitchem and Wells (2002) study used for this study included general demographics, type of IT used, type of 
instructional strategies, and IT integrations. The IICI is specific to Trek 21 and as such represents only IT integrations that were the focus of the institute and represented in the participants’ units. Specific categories of The Indicators of Instructional Change Instrument (IICI) were used to address particular research questions for this study. Research Question 1: What types of instructional media do P-12 teachers integrate into web-based learning?

RQ 1 was addressed using data from the third section of the IICI: IT Integration. Extant data indicated specific types of instructional technologies/media used for webbased instruction in a P-12 setting. This information served to provide the types of media that should be present in lessons. Data from all three years of Trek $21(\mathrm{~N}=107)$ were used.

Research Question 2: In what ways are the instructional media used?

RQ 2 was addressed using data from the second section (Instructional Strategies) and the third section (IT Integrations) of the IICI. This information served to provide the instructional strategies that should be present in lessons. The types of instructional media were analyzed to determine which instructional strategy was associated with specific instructional media. Data from all three years of Trek $21(\mathrm{~N}=107)$ were used to extract a sample of participants who integrated three or more instructional media in a lesson. A lesson from each unit of the participants selected for the sample was reswept to obtain data for RQ 3.

Research Question 3: What is the level of engagement with the instructional media? 
RQ 3 was addressed using data from the third section of the IICI: Instructional Technologies. This information served to provide the types of media that should be present in lessons. Data from all years of Trek $21(\mathrm{~N}=107)$ were used to identify if instructional media were present in a lesson. Of the lessons where instructional media were present, student engagement was recorded as either active or non-active.

To explore the use of instructional technologies and levels of student learning more in-depth, two additional research questions examined the relationship between instructional media and cognitive levels of learning and used a purposeful sampling of the original population. In contrast to random sampling, purposeful sampling targets information rich cases to study in-depth (Patton, 1990). The strength of purposeful sampling lies in the fact that an in-depth study yields much insight about the topic of interest whereas probability or random sampling depends upon selecting a "random or statistically representative sample for generalization to a larger population” (McMillan \& Schumacher, 1997, p. 237). The selection of participants for the purposeful sampling is described in the Procedure section. RQ 4 and RQ 5 are specific to that purposeful sampling.

Research Question 4: What level of learning did the instructional media/technology address?

RQ 4 was addressed by first using the IICI (Appendix A) to sweep or analyze every lesson in every unit prepared by the participants selected for the purposeful sampling. The IICI was previously used by Trek 21 evaluators to complete a random lesson sweep of one lesson per unit, per person. This researcher used the IICI in a comprehensive lesson sweep to examine five lessons of the units prepared by the 
sampling participants. Instructional media and associated instructional strategies were identified using Bloom’s (1956) taxonomy (Appendix B), which ranks educational objectives progressively from low to high on a scale of one to six, each IM identified by the IICI comprehensive lesson sweep was ranked. A numerical associated with the cognitive levels of learning (Lever-Duffy, McDonald, \& Mizell, 2003) based on the ranking from Bloom's taxonomy was given to every IM in each of the five lessons that the participants in the sampling prepared. The progressive cognitive levels associated with the thinking skills of learners include knowledge, comprehension, application, analyses, synthesis, and evaluation (Lever-Duffy, et al.). Rankings that represented the level of cognitive learning based on Bloom's taxonomy were linked with every IM, in every lesson, for each of the participants in the sampling.

Research Question 5: Is there a correlation between types and use of instructional media and cognitive levels of learning?

RQ 5 was addressed using Tomei’s (2001) Instructional Technology Taxonomy (Appendix C). Tomei’s taxonomy, unlike Bloom’s (1956) which addressed cognitive levels, specifically addressed the intellectual activity associated with the use of technology. The technology taxonomy classifies actions that represent intellectual activity progressively, "from simple to complex, first to last, and general to specific" (Tomei, 2002, p. 68). The range of intellectual activity associated with technology is from Level 1: literacy, (low), to Level 6: acculturation, (high). Tomei’s Instructional Technology Taxonomy (Appendix C) was used to represent the level of intellectual activity and was linked to every IM, in every lesson, for each of the participants in the intensity sampling. Each IM was given a numerical rank based on Tomei's (2001) 
instructional technology taxonomy (six levels) and later compared to its ranking with Bloom's taxonomy (six levels) to examine the correlation between the IM and its use.

Procedure

\section{Data Gathering and Analysis}

Grant information and project documents were obtained from the project director in May 2002 and from the PT3 web site (www.PT3.org). This information served to familiarize the researcher with the history of the PT3 project grant areas of the U.S. Department of Education and the purpose of Trek 21. Statistical information was discussed during interviews and later acquired from project evaluators in the fall of 2002. These data were used to identify instructional media (IM) specific to Trek 21 and to formulate and address questions for this research. Information from conference papers and presentations was obtained from the research section of the Trek 21 web site (www.trek-21.wvu.edu) from fall 2001 to summer of 2003. Existing papers and studies added various perspectives and comparisons between Trek 21 institutes in areas such as instructional change, sustaining effective practices, integration of instructional technology, and professional development. Background information about Trek 21 and the dissemination efforts were discussed in the Literature Review.

\section{Research Questions}

IM specific to Trek 21 are the focus of instructional technologies for this study. IM were identified by the researcher for RQ 1 by noting ITs listed on the IICI (Appendix A) by project evaluators. After field testing the IICI instrument and reviewing Trek 21 web-based units, Mitchem and Wells (2002), designers of the instrument, excluded an 
instructional medium (MUD/MOO) and separated Internet access and information

retrieval leaving only the items specific to web units prepared by Institute participants.

This researcher reswept the 107 lessons using the IICI and recorded information

for RQ 1. The IM found in this sweep are representative of the types of IM used in P-12

web-based instruction. Table 6 reflects the research design and summarizes the

instrumentation, analysis, and outcome for each research question.

Table 6

Overview of Research Questions and Instrumentation

\begin{tabular}{|c|c|c|c|c|c|}
\hline & $\begin{array}{c}\text { Research } \\
\text { Question } \\
\end{array}$ & Data Source & Analysis & Expected Outcomes & $\mathbf{N}$ \\
\hline 1. & $\begin{array}{l}\text { What types of } \\
\text { instructional } \\
\text { media do P-12 } \\
\text { teachers integrate } \\
\text { into web-based } \\
\text { learning? }\end{array}$ & $\begin{array}{l}\text { - Indicators of } \\
\text { Instructional } \\
\text { Change-Random } \\
\text { Lesson Sweep, } \\
\text { Section } 3 .\end{array}$ & $\begin{array}{l}\text { Types of IM used in } \\
\text { P-12 web-based } \\
\text { instruction. }\end{array}$ & - Frequency count & - $\mathrm{N}=107$ \\
\hline \multirow[t]{2}{*}{2.} & $\begin{array}{l}\text { In what ways are } \\
\text { the instructional } \\
\text { media used? }\end{array}$ & $\begin{array}{l}\text { - Indicators of } \\
\text { Instructional } \\
\text { Change-Random } \\
\text { Lesson Sweep } \\
\text { (IICI), Section } 2 .\end{array}$ & - IM present & - Frequency count & - $\mathrm{N}=107$ \\
\hline & & - IICI & - IS specific to IM & - Descriptive data & - $n=36$ \\
\hline 3. & $\begin{array}{l}\text { What is the level } \\
\text { of student } \\
\text { engagement with } \\
\text { the instructional } \\
\text { media? }\end{array}$ & $\begin{array}{l}\text { - Indicators of } \\
\text { Instructional } \\
\text { Change--Random } \\
\text { Lesson Sweep }\end{array}$ & $\begin{array}{l}\text { - Raw Data: active \& } \\
\text { non-active IM }\end{array}$ & - Frequency count & $\mathrm{N}=107$ \\
\hline 4. & $\begin{array}{l}\text { What level of } \\
\text { learning did the } \\
\text { instructional } \\
\text { media address? }\end{array}$ & $\begin{array}{l}\text { - Bloom’s } \\
\text { Taxonomy }\end{array}$ & $\begin{array}{l}\text { - Level of cognitive } \\
\text { learning. }\end{array}$ & - Numerical value & $n=9$ \\
\hline 5. & $\begin{array}{l}\text { Is there a } \\
\text { correlation } \\
\text { between } \\
\text { instructional } \\
\text { media and } \\
\text { cognitive levels } \\
\text { of learning? }\end{array}$ & $\begin{array}{l}\text { - Tomei’s } \\
\text { Taxonomy } \\
\text { • Bloom's } \\
\text { Taxonomy } \\
\text { • Interview analysis }\end{array}$ & $\begin{array}{l}\text { Levels of technology } \\
\text { integration } \\
\text { - Levels of higher order } \\
\text { thinking } \\
\text { - Interview data }\end{array}$ & $\begin{array}{l}\text { - Numerical value. } \\
\text { • Numerical value }\end{array}$ & $n=9$ \\
\hline
\end{tabular}


The way in which the instructional media were used, RQ 2 (Table 6), was noted in section 2 of the IICI (Appendix A). These included instructional strategies adapted from a literature-based, field-tested rubric and were present in participants’ web-based units. According to Mitchem \& Wells (2002) random sweeps with the IICI were completed for each of the three years of Trek 21. Each of the thirteen categories in this section was summed, resulting in frequency counts. This data were later used by this researcher to assist in determining types of instructional strategies present in units so that an instructional strategy could be linked to a specific instructional media.

The IICI (Appendix A) was used by Trek evaluators during lesson sweeps $(\mathrm{N}=107)$ to examine active student engagement with the instructional media with overt student responses to an instructional objective being scored as present or not and of the lessons where instructional media were present, active or not-active (indicated with a +) or not (Mitchem, et al., 2002). Frequency counts were recorded for active and non-active ITs/IM by this researcher. Data were used to address RQ 3 and to select a sampling of participants for in-depth interviews and analysis.

Data gathered for RQ 4 (Table 6) using Bloom’s (1956) taxonomy for educational objectives (Appendix B) were documented for every lesson developed by Trek 21 participants chosen for purposeful sampling. Instructional strategies associated with instructional media were identified according to learner actions using Bloom's taxonomy to guide the classification. Once an instructional strategy was linked to an instructional media, the IM was assigned a numerical value associated with a level of learning on Bloom's taxonomy. The numerical value was used to examine the relationship between instructional media and cognitive levels of learning. 
Data gathered for RQ 5 (Table 6) using Tomei’s (2001) instructional technology taxonomy (Appendix C) were recorded for every lesson developed by Trek 21 participants who were chosen for purposeful sampling. Numerical rankings related to the characteristics associated with cognitive levels of learning and numerical rankings associated with intellectual activity linked to an instructional technology were recorded for each IM in each of the five lessons of the participants selected for an in-depth investigation. The hypothesis is that a relationship exists between types and use of instructional media and cognitive levels of learning. The numerical value of ranks associated with instructional media and instructional strategies according to Bloom's (1956) (RQ 4) and Tomei's taxonomies (RQ 5) were entered into a statistical software program for further analysis.

In-Depth

Mixed methods strategies, ones which include both quantitative and qualitative methods, are sometimes used in research. To study the relationship between types and use of instructional media and cognitive levels of learning (RQ 5) a sampling of participants who indicated a high use of active IM in their lesson plans was selected in order to explore the phenomenon more closely. Of the two types of qualitative inquiry “interactive field research or noninteractive document research” (McMillan \& Schumacher, 1997, p. 389), this study will employ the later, which according to the authors, is primarily used for studying past events.

Limitations. Qualitative researchers recognize the hesitance of some to generalize findings from an in-depth inquiry to a larger population (Merriam, 1988; Patton, 1987). In order to strengthen the study, the researcher adds validity to the study by following 
standard sampling procedures (Merriam). However, as Patton stated, some researchers argue against generalization, believing that generalization decays over time. This is more important when completing a research study that involves particular technologies, such as this one, because of rapid technological changes and innovations. By using a carefully selected sampling of information-rich examples, some extrapolation of data may be possible (Patton).

Sampling. By studying a purposeful sampling of participants who exhibited high use of active IM, a pattern is expected to emerge and indicate particular IM that would promote high cognitive thinking, the focal point of this study. Of the various types of purposeful sampling described in the review of literature, the researcher felt that an intensity sampling, one that studies intense examples of a phenomenon of interest (Patton, 1990) would be a credible method to offer a different perspective on extant data. This type of sampling has been used in educational studies (Oka \& Shaw, 2000) and is well suited to this study in that intensity sampling focuses on rich examples of interest and does not focus on extreme cases which may be so extreme that they distort data (Patton).

Criteria for selecting participants for in-depth analysis were based on high use of IM, grade level, and year of enrollment in the institute. The intensity sampling in this study included one person from each grade level (preschool, elementary, middle school, high school) for each of the three years of Trek 21 who was identified as a high use participant. (High use participants were those who integrated three or more instructional media in the lesson selected during random sampling.) This sampling technique assured a proportional representation of the population (Hopkins, 2000) and reflected the stratified 
random sampling procedure that Trek 21 evaluators used in their comprehensive and random lesson sweep analysis of participants’ web-based instructional units.

In order to identify potential participants for the intensity sampling, the number of active IM utilized in the participants' web-based instructional units for in each of the three years of the institute had to be determined first. IM were recorded using data from the IICI (Appendix A) random lesson sweeps by grade level (preschool, elementary, middle school, and high school), for each participant, for each year. From the list of IM users per grade level, an intensity sampling was derived for each of the three years of Trek 21 to represent information rich examples for an in-depth study.

Email messages were sent to the participants chosen for the intensity sampling. The email included a brief overview of the purpose of the study, and asked if the participant would agree to an interview. Participants were reminded that their participation was voluntary, that their information was confidential, and that their identity would not be revealed. Participants who did not respond within three days were sent a second request. If a participant failed to respond to the second request, the next person on the list who met the same criteria was contacted. Individual interviews began during the spring of 2004.

Interview. After the selected individuals agreed to participate, options regarding time, place of interviews, and consent to being audio taped were accomplished in subsequent email messages or phone calls to each participant. A discussion of the interview procedure was emailed to each participant prior to the interview with an outline of general topics. As suggested by McMillan and Schumacher (1997) the participants received an estimation of how long the interview was expected to take, in this study, 
about a half hour in length. Interview information indicated that only one interview would be needed, but that additional contact might be requested in order to clarify information obtained during the interview. Before the interview began, participants were reminded that their identity would be kept confidential and that their participation was voluntary.

Each participant was asked the same set of open-ended questions (Appendix E) specific to the study. Various types of interview questions - experience, opinions, feelings, knowledge, sensory, demographic —-were used to illicit information from the perspective of the participants (McMillan \& Schumacher, 1997; Patton, 1990). This process is utilized when a study involves past events (Merriam, 1988) and procedures that cannot be directly observed (Patton, 1990). Questions were intended to seek descriptions of the setting and use of the web-based instructional unit, general background of the individual, the experience that the teacher had with the web-based instructional unit, the knowledge of the teacher with regard to the integration of the unit into the learning environment, and specific research questions.

This information was sought to examine teachers’ perceptions of IM usage, which exemplifies practical knowledge (Merriam, 1988), and adds rich details to the study (Patton, 1990). Prompts or probes were designed to elicit additional detail for research questions (Appendix E.) or clarification if needed (Patton, 1990). Interview questions (IQ) were designed to address: a) the types of IM that were integrated into the participant's web-based unit and why those particular IM were selected [RQ 1, IQ 2b] how the IM were used in the web-based unit [RQ 2, IQ 3], c) student engagement [RQ 3, IQ 3b], and d) what IM the students were most responsive to [RQ 4, IQ 7; RQ 5, IQ 6]. 
During each interview the researcher asked the questions in the same order, wrote notes (key phrases, key words, observations, reactions), and audio taped the interview. Taped responses were transcribed by the researcher and compared to notes taken during the interview. Emergent themes from the interviews were categorized using a key-word taxonomy to clarify and delineate descriptive information for further analysis. A key word frequency taxonomy that included responses from all participants in the sampling was aligned with research questions to illuminate emergent patterns. Participant’s responses were expected to illustrate a correlation between type and use of ITs and the cognitive levels of learning (RQ 5). This study will add to the literature by identifying the correlation through mixed methods, quantitative and qualitative, and from various personal perspectives (participants in the study).

Researcher. "The inquirer uses a viewpoint for establishing validity in a study. Qualitative inquirers bring to their studies a different lens toward validity than that brought to traditional, quantitative studies” (Creswell \& Miller, 2000, p. 124). Knowledge about the role of the researcher is especially important to this study as she was involved with the Trek 21 project and had experience with multimedia web-based instruction.

The researcher participated in the continuity meetings of the first year of the Trek 21 project. She was an instructional leader for both the second and third years of the institute. The role of an instructional leader was to provide participants with a pedagogical foundation for their units and to assist the participants in gaining skill and knowledge of instructional technologies. The goal was integration of the pedagogy and instructional technologies into technology-enhanced web-based lessons. In addition, 
instructional leaders reviewed completed units prior to posting to the Trek 21 server and attended continuity meetings. It should be noted that the researcher, although primarily associated with higher education, had some prior experience teaching in P-12 settings. Since the participants in this study are from that genre, this prior experience provided some insight into the P-12 classroom setting.

\section{Stages of Data Analysis}

Mixed methods studies combine quantitative and qualitative research methodologies into one study. This paper will examine the research questions based on quantitative data. The last research question (RQ 5) will be addressed through both quantitative and qualitative data analysis. Because this last research question is based upon findings in the first four RQs, qualitative analysis is expected to complement all of the research questions in this study. The stages of quantitative and qualitative analysis for this study are displayed in Figure 1. Results and discussion of data will conclude the analysis of research questions. 
Figure 1. Stages of Quantitative and Qualitative Analysis

\section{Quantitative}

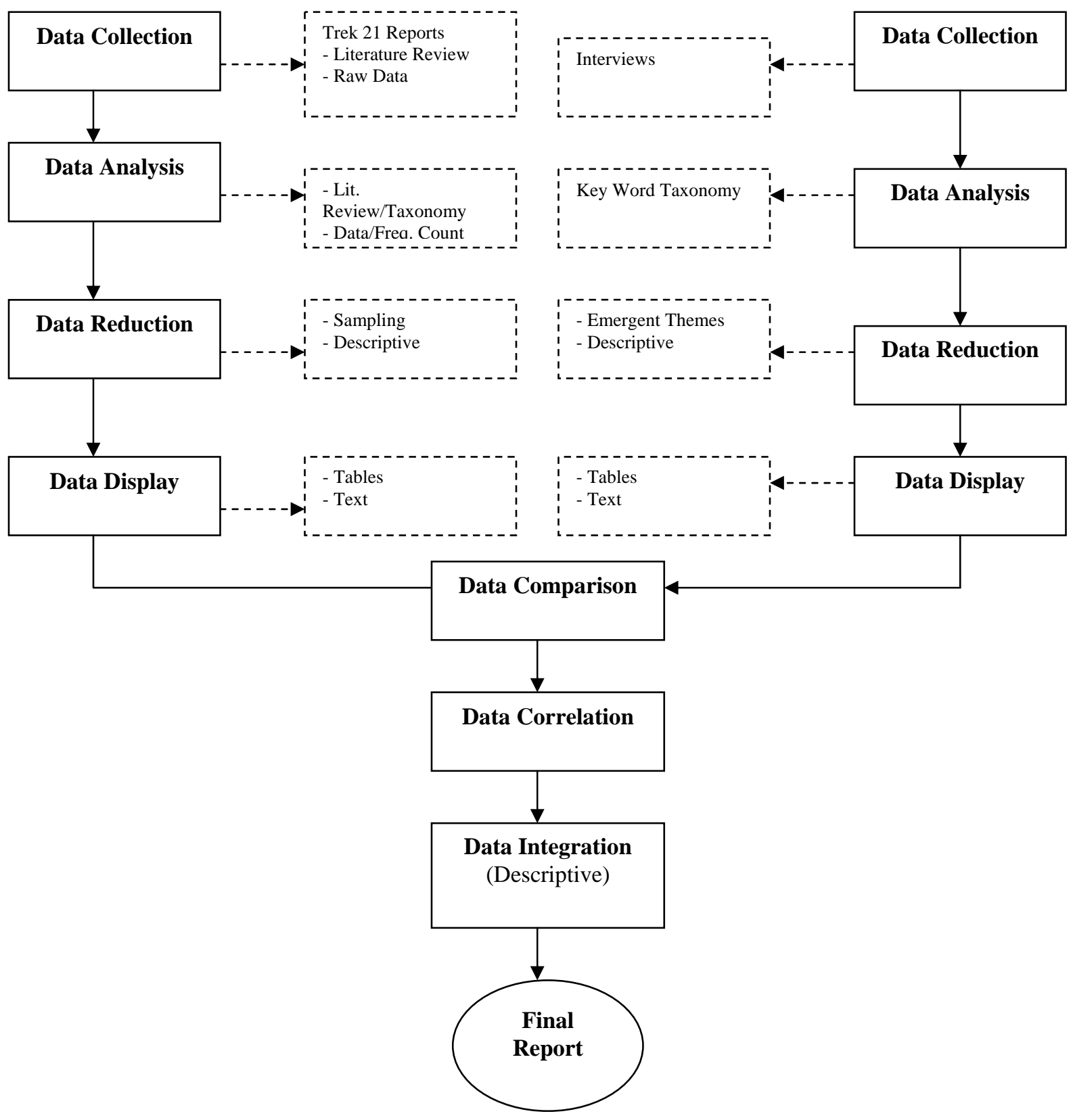

Note: Adapted from Handbook of Mixed Methods in Social \& Behavioral Research, Tashakkori \& Teddlie, Editors, 1998 


\section{Chapter IV}

Results

In this chapter, results are reported for Research Questions One through Five as described in Chapter III. The research questions investigated the types of instructional media that P-12 teachers integrated into web-based learning, the ways in which instructional media were used, the level of student engagement with the instructional media, the level of learning that the instructional media addressed, and the correlation between types and uses of instructional media and the cognitive levels of learning. The participants in this study were P-12 teachers who developed web-based units of instruction as part of a professional development held for three weeks during three consecutive summers.

Research Question 1: What Types of Instructional Media do P-12 Teachers Integrate into Web-Based Learning?

Data from all three years of Trek $21(\mathrm{~N}=107)$ were used to determine types of instructional media that P-12 teachers integrated into web-based learning. One lesson from each of the 107 web-based units developed by the participants during the three years of the institute was examined for types of instructional media used. Of the 13 instructional media the IICI (Appendix A) swept for, 12 were distinct in their frequency of use. The instructional media were computer-aided instruction/drill and practice, simulation/educational games, word processing, information retrieval, Internet access, email, bulletin boards/listservs, authoring/multimedia development, desktop publishing, electronic presentations, video, and open lab access. 
Table 7 summarizes the frequency that IM were integrated into the lessons swept for study. A percentage of use based on the total number of all integrated instructional media demonstrates that of the 210 instructional media some were used more frequently than others. The frequency count reveals that three most frequently used IM by teachers account for nearly $75 \%$ of all media combined. The remaining IM, though consistently low over the three years, did show a gradual increase in use. This increased use could be attributed to augmented skills of participants, a greater use of technology by school systems, increased access to IM, and/or improved/upgraded software and hardware. Of the less frequently used IM there is a general trend in the use of email. A closer study of the ways in which these IM were integrated into lessons will help to explain this trend.

\section{Table 7}

Frequency of Integration of Instructional Media Years 1- 3

\begin{tabular}{rrrrrr}
\hline \multicolumn{1}{c}{ Instructional Media } & Year 1 & Year 2 & Year 3 & Total & \\
\hline Internet Access & 25 & 18 & 21 & $\mathbf{6 4}$ & $\mathbf{3 0 \%}$ \\
Information Retrieval & 22 & 16 & 17 & $\mathbf{5 5}$ & $\mathbf{2 6 \%}$ \\
Electronic Presentations & 12 & 8 & 16 & $\mathbf{3 6}$ & $\mathbf{1 7 \%}$ \\
Simulation/Ed. Games & 5 & 4 & 4 & $\mathbf{1 3}$ & $\mathbf{6 \%}$ \\
Word Processing & 4 & 3 & 3 & $\mathbf{1 0}$ & $\mathbf{5 \%}$ \\
E-mail & 1 & 1 & 7 & $\mathbf{9}$ & $\mathbf{4 \%}$ \\
Open Lab Access & 5 & 4 & 0 & $\mathbf{9}$ & $\mathbf{4 \%}$ \\
Desktop Publishing & 2 & 1 & 2 & $\mathbf{5}$ & $\mathbf{2 \%}$ \\
Authoring/Multimedia Dev. & 0 & 1 & 2 & $\mathbf{3}$ & $\mathbf{1 \%}$ \\
Video Development & 1 & 0 & 2 & $\mathbf{3}$ & $\mathbf{1 \%}$ \\
Bulletin Boards/Listservs & 0 & 2 & 0 & $\mathbf{2}$ & $<\mathbf{1 \%}$ \\
CAI/Drill and Practice & 0 & 0 & 1 & $\mathbf{1}$ & $<\mathbf{1 \%}$ \\
Web Page Development & 0 & 0 & 0 & $\mathbf{0}$ & $\mathbf{0 \%}$ \\
\hline
\end{tabular}

Note: Percentages are rounded. 
Research Question 2: In What Ways Are the Instructional Media Used?

Data from all three years of Trek $21(\mathrm{~N}=107)$ were used to determine ways instructional media were integrated into web-based learning. In order to study the ways in which participants used instructional media, lessons were reviewed from the random sweep that revealed which lessons exhibited multiple incidences of integrated IM. In analyzing the 107 lessons, the incidences of integration of IM in a given lesson ranged from 1 to 6 . The median, or the number which divides a rank-ordered distribution (McMillan \& Schumacher, 1997) was calculated as 3.5 using the range of one (lowest number) to six (highest number of IM integrated in a single lesson). In order to have statistical inclusion, the criterion for high usage participants was the integration of three or more IM into the one lesson. Pre-K, because of the low total number of participants, was included with the elementary school category. Based on the median, the random lesson sweep showed 36 lessons (Table 8), 12 from each year, which included three or more IM in the lesson.

Table 8

Lessons with Three or More Instructional Media

\begin{tabular}{|c|c|c|c|c|c|c|c|c|}
\hline \multicolumn{3}{|c|}{ Year $1 \quad n=12$} & \multicolumn{3}{|c|}{ Year $2 \quad n=12$} & \multicolumn{3}{|c|}{$\begin{array}{ll}\text { Year } 3 & n=12 \\
\end{array}$} \\
\hline Grade & ID \# & \# of IM & Grade & ID \# & \# of IM & Grade & ID\# & \# of IM \\
\hline Elem & 34 & 4 & Middle & 9 & 6 & Middle & 92 & 5 \\
\hline High & 30 & 3 & Elem & 6 & 4 & Elem & 74 & 4 \\
\hline Elem & 36 & 3 & Elem & 11 & 4 & Elem & 88 & 4 \\
\hline High & 46 & 3 & Middle & 13 & 4 & Elem & 90 & 4 \\
\hline High & 47 & 3 & Elem & 23 & 4 & Elem & 98 & 4 \\
\hline High & 48 & 3 & Elem & 27 & 3 & High & 100 & 4 \\
\hline High & 50 & 3 & High & 5 & 3 & Elem & 107 & 4 \\
\hline Elem & 52 & 3 & Elem & 8 & 3 & Elem & 73 & 3 \\
\hline Elem & 56 & 3 & Elem & 10 & 3 & Middle & 78 & 3 \\
\hline Elem & 66 & 3 & High & 15 & 3 & Elem & 89 & 3 \\
\hline Middle & 68 & 3 & Elem & 17 & 3 & High & 101 & 3 \\
\hline Elem & 72 & 3 & Elem & 24 & 3 & Elem & 102 & 3 \\
\hline
\end{tabular}


The results of a recent frequency count of the lessons in which instructional media were integrated revealed additional incidences where instructional media were integrated. This difference from the initial random lesson could be due to some teachers uploading additional activities and IM to their lessons since the original data was collected in 2001. To analyze the ways in which these media were used, a two-dimensional table was set up to align instructional media with instructional strategies.

Table 9

Instructional Media and Instructional Strategies Used in Lessons

\begin{tabular}{|c|c|c|c|c|c|c|c|c|c|c|c|c|}
\hline $\begin{array}{r}\text { Instructional } \\
\text { Media }\end{array}$ & 昜 & 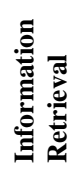 & 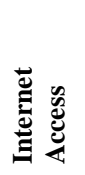 & 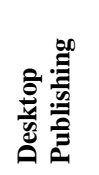 & $\begin{array}{l}\text { 馬 } \\
\text { 馬 }\end{array}$ & 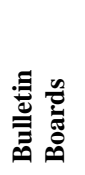 & 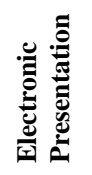 & 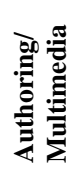 & 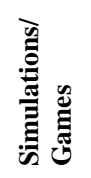 & 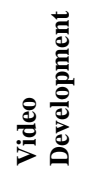 & $\begin{array}{l}\text { 苂 } \\
\text { పัّ }\end{array}$ & \\
\hline $\begin{array}{r}\text { Instructional } \\
\text { Strategy }\end{array}$ & & & & & & & & & & & & $\begin{array}{c}\text { IS } \\
\text { Totals }\end{array}$ \\
\hline $\begin{array}{r}\text { Writing/ } \\
\text { Journaling }\end{array}$ & 5 & 0 & 0 & 0 & 1 & 0 & 0 & 1 & 0 & 0 & 0 & 7 \\
\hline $\begin{array}{c}\text { Problem } \\
\text { Solving }\end{array}$ & 0 & 2 & 2 & 3 & 0 & 0 & 0 & 0 & 4 & 1 & 2 & 14 \\
\hline Inquiry & 0 & 1 & 24 & 0 & 0 & 0 & 0 & 0 & 0 & 0 & 0 & 25 \\
\hline $\begin{array}{r}\text { Student } \\
\text { Presentation }\end{array}$ & 1 & 0 & 1 & 2 & 0 & 0 & 4 & 2 & 0 & 0 & 0 & 10 \\
\hline Research & 0 & 16 & 1 & 0 & 0 & 0 & 0 & 0 & 0 & 0 & 0 & 17 \\
\hline $\begin{array}{r}\text { Peer } \\
\text { Mediated }\end{array}$ & 0 & 0 & 2 & 0 & 3 & 1 & 0 & 0 & 0 & 0 & 0 & 6 \\
\hline $\begin{array}{l}\text { Advanced } \\
\text { Organizer }\end{array}$ & 15 & 8 & 8 & 0 & 0 & 0 & 0 & 0 & 0 & 3 & 0 & 34 \\
\hline $\begin{array}{l}\text { Whole Group } \\
\text { Instruction }\end{array}$ & 0 & 0 & 7 & 0 & 0 & 1 & 2 & 0 & 0 & 0 & 0 & 10 \\
\hline $\begin{array}{r}\text { Teacher } \\
\text { Demo }\end{array}$ & 0 & 0 & 0 & 0 & 0 & 0 & 21 & 0 & 0 & 0 & 0 & 21 \\
\hline $\begin{array}{r}\text { Hands-on } \\
\text { Manipulative }\end{array}$ & 0 & 0 & 0 & 0 & 0 & 0 & 0 & 1 & 0 & 0 & 3 & 4 \\
\hline $\begin{array}{r}\text { Active } \\
\text { Responding }\end{array}$ & 6 & 6 & 16 & 0 & 2 & 0 & 2 & 0 & 5 & 0 & 1 & 38 \\
\hline IM totals & 27 & 33 & 61 & 5 & 6 & 2 & 29 & 4 & 9 & 4 & 6 & 196 \\
\hline
\end{tabular}

A repeat lesson sweep was performed for each lesson to identify ways that the IM were integrated. To identify ways in which IM were used, instructional strategies were identified from the lesson sweep tool that revealed instructional strategies found in the 
lessons. However, the Trek evaluators did not associate a specific instructional strategy with a specific instructional medium. A repeated lesson sweep and an analysis of the ways in which the IM were integrated revealed that 11 of the 13 instructional strategies were reflective of the ways in which instructional media were used. Table 9 was created to illustrate the alignment of IS to IM in order to examine ways in which the IM were used.

The table illustrates that the most frequently chosen instructional strategy associated with IM was Inquiry, which was associated with Internet Access. Second most frequently chosen IS was Teacher Demonstrations, which was associated with Electronic Presentations. These were followed by Research associated with Information Retrieval, and Word Processing used most often as an advanced organizer. Therefore, the ways in which IM were used was primarily via these four main instructional strategies, which, of all possible instructional strategies, were used for more than half of the lessons or $60 \%$.

Research Question 3: What is the Level of Student Engagement with the Instructional Media?

Data from all three of Trek $21(\mathrm{~N}=107)$ were used to determine the level of student engagement with the active instructional media (IM). The results of a random lesson sweep of one lesson selected from each unit of the participants indicated that not all of the lessons had IM. Table 10 illustrates the percentage of reviewed lessons with IM and the percentage of lessons without instructional media. The table reveals that across the three years of the Institute $81 \%$ of the lessons included instructional media. 
Table 10

Number of Lessons With and Without Instructional Media, Years 1-3

\begin{tabular}{ccc}
\hline & $\begin{array}{c}\text { Lessons } \\
\text { Without IM }\end{array}$ & $\begin{array}{c}\text { Lessons } \\
\text { With IM }\end{array}$ \\
\hline Year 1 & $24 \%$ & $76 \%$ \\
Year 2 & $15 \%$ & $85 \%$ \\
Year 3 & $14 \%$ & $86 \%$ \\
\hline Totals & $\mathbf{1 9 \%}$ & $\mathbf{8 1 \%}$ \\
\hline
\end{tabular}

In addition to identifying lessons with instructional media, the sweep tool (Appendix A) identified those IM that actively engaged students. This IICI sweep identified the level of student engagement as either active or non-active. Appendix F illustrates the total number of instructional media in each lesson, active IM, and nonactive IM Year 1 through Year 3. Table 11 summarizes the percentages and number of lessons with active instructional media and those with non-active instructional media. Of the lessons that included instructional media, Year 2 had the highest percentage of lessons with active IM and the lowest number of lessons with non-active media. This could be attributed to a greater focus on active IM during the second year of the institute or change in the Institute's design during Year 3.

Table 11

Number of Lessons with Active and Non-Active Instructional Media

\begin{tabular}{lccc}
\hline & Lessons with IM & Non-Active IM & Active IM \\
\hline Year 1 & 34 & $15 \%$ & $85 \%$ \\
$\mathrm{~N}=45$ & & & \\
Year 2 & 23 & $4 \%$ & $96 \%$ \\
$\mathrm{~N}=27$ & & & \\
Year 3 & 30 & $20 \%$ & $80 \%$ \\
$\mathrm{~N}=35$ & & $\mathbf{1 4 \%}$ & $\mathbf{8 6 \%}$ \\
\hline Totals & $\mathbf{8 7}$ & &
\end{tabular}


When IM were present in a lesson, the IM engaged students. Across all three years when instructional media were present, $86 \%$ of the time the IM were actively engaging learners. Therefore, instructional media, when present in a lesson, actively engages learners.

Research Question 4: What Level of Learning Did the Instructional Media Address?

To explore the level of learning that the IM addressed, a purposeful sampling of the participants who integrated a high number of active instructional media was obtained for an in-depth analysis of lessons and IM integration. Lessons of participants who exhibited a high number of IM were expected to reveal the richest variety and use of IM. By studying a purposeful sampling of participants who exhibited high use of active IM, a pattern was expected to emerge indicating which IM teachers integrate most frequently for web-based content, and what level of learning these IM addressed.

The list of 36 high use participants who integrated three or more IM in one randomly selected lesson (RQ2) was stratified by grade level (preschool combined with elementary school, middle school, and high school). This stratified sampling (Table 12), a proportionate representation of high use IM users across all years and for all grades levels, was expected to yield a wide variety of IM for diverse content areas and for various instructional levels. The in-depth analysis included interviews, and a comprehensive lesson sweep that examined specific instructional strategies associated with instructional media in five lessons of each the participant's units selected for indepth analysis. Data from interviews and web-based units were expected to corroborate lesson sweep data and provide detailed exemplars of IM integration. 
Table 12

High Use of IM Across All Years by Grade Level, $n=36$

\begin{tabular}{|c|c|c|c|c|c|c|c|c|}
\hline \multirow[b]{2}{*}{$\begin{array}{l}\text { Grade } \\
\text { Level }\end{array}$} & \multicolumn{2}{|l|}{ Year 1} & \multirow[b]{2}{*}{ ID } & \multicolumn{2}{|l|}{ Year 2} & \multirow[b]{2}{*}{ ID } & \multicolumn{2}{|l|}{ Year 3} \\
\hline & ID & $\begin{array}{l}\text { Active IM } \\
\text { Post-Inst. }\end{array}$ & & $\begin{array}{c}\text { Active IM } \\
\text { Pre-Inst. }\end{array}$ & $\begin{array}{l}\text { Active IM } \\
\text { Post-Inst. }\end{array}$ & & $\begin{array}{c}\text { Active IM } \\
\text { Pre-Inst. }\end{array}$ & $\begin{array}{l}\text { Active IM } \\
\text { Post-Inst. }\end{array}$ \\
\hline \multicolumn{9}{|l|}{ PK/Elem. } \\
\hline & \# 34 & 4 & $\# 6$ & 0 & 4 & \# 73 & 0 & 3 \\
\hline & \# 36 & 3 & \# 8 & 0 & 3 & \# 74 & 1 & 4 \\
\hline & \# 52 & 3 & \# 10 & 0 & 3 & \# 88 & 2 & 4 \\
\hline & \# 56 & 3 & \# 11 & 1 & 4 & \# 89 & 0 & 3 \\
\hline & \# 66 & 3 & \# 17 & 0 & 3 & \# 90 & 0 & 4 \\
\hline & \# 72 & 3 & \# 23 & 0 & 4 & \# 98 & 0 & 4 \\
\hline & & & \# 24 & 3 & 3 & \# 102 & 0 & 3 \\
\hline & & & \# 27 & 0 & 4 & \# 107 & 2 & 4 \\
\hline \multicolumn{9}{|l|}{ Middle } \\
\hline & \# 68 & 3 & $\# 9$ & 1 & 6 & \# 78 & 0 & 3 \\
\hline & & & \# 13 & 0 & 4 & \# 92 & 5 & 5 \\
\hline \multicolumn{9}{|l|}{ High } \\
\hline & \# 30 & 3 & $\# 5$ & 0 & 3 & \# 100 & 3 & 4 \\
\hline & \# 46 & 3 & \#15 & 2 & 3 & \# 101 & 2 & 3 \\
\hline & \# 47 & 3 & & & & & & \\
\hline & \# 48 & 3 & & & & & & \\
\hline & \# 50 & 3 & & & & & & \\
\hline & $n=12$ & & $n=12$ & & & $n=12$ & & \\
\hline
\end{tabular}

Note: There were no active IM pre-institute for Year 1.

From the 36 high use participants, nine were selected as an intensity sampling beginning with the participant with the highest number of IM for each year. This sample included one person from each grade level for each year, and was performed in order to conduct interviews and full unit sweeps on a smaller, representative group of participants. If two or more participants integrated an identical number of active IM, the participant whose total number of active IM exhibited the greater change from pre- to post-institute counts was contacted first for an interview. For example, a participant who integrated two active IM before participating in Trek 21 and integrated four active IM after participating in Trek 21 was the preferred selection over a participant who integrated three active IM 
pre-institute and four active IM post-institute. Participants with the greater range from pre-institute to post-institute showed the most growth after training next to participants who had already integrated three or more IM.

Participants selected for the intensity sampling were contacted by email or by phone if an email address was not available. Each participant received an overview of the study by email as an attached file, and a request to participate in the study. The results of the final selection of participants for the intensity sample were coded to conceal their identity and are illustrated in Table 13 with general demographics.

Table 13

Demographics of Sampling

\begin{tabular}{lll}
\hline \multicolumn{1}{c}{ ID } & \multicolumn{1}{c}{ Content Area(s) } & \multicolumn{1}{c}{ County } \\
\hline Alice & - Language Arts & Taylor \\
Bob & Mathematics & Preston \\
Cara & - Environmental Science \& Foreign Language & Marion \\
Dora & Science & Monongalia \\
Edd & - Science \& History & Preston \\
Fran & - Social Studies \& History & Monongalia \\
Gina & Physical Education & Preston \\
Hana & Arts & Monongalia \\
Izzy & Mathematics & Preston \\
\hline
\end{tabular}

Demographics of Sampling. Of the nine people selected by the intensity sampling process, one person was represented in both Year 1 and Year 2. As a result, and to avoid bias, interview questions for this individual were repeated for the unit developed in Year 2 and clearly coded throughout the interview and analysis process. Therefore, nine interviews were conducted with eight people. The participants represented four counties, various content areas, and grade levels across the three years of the Institute. 
Review of Web-based Units. All nine web-based units developed by the participants selected through the intensity sampling process were captured from the Trek 21 web site (www.trek-21.wvu.edu) using Adobe Acrobat and saved in a portable document format (pdf). This process allowed viewing offline. All external links in the captured lessons remained active. Internal links in the captured site were inactive, but files such as word documents, portable document files, videos, and presentations associated with the participant's site were downloaded and were either added to the captured site or placed in a folder with the unit. This procedure made all files associated with the site readily available for review.

Customized Taxonomy. Specific instructional strategies, those that were indicated by lesson sweep analysis as being present in the lessons, were used as guidelines to match the IM with the description of learner actions and action verbs with the appropriate learning domains (knowledge, comprehension, application, analysis, synthesis, and evaluation) according to the Bloom's (1956) taxonomy. As an example (Table 14), a learner action associated with Knowledge included recalling content or memorization of definitions. Action verbs included define, label, and identify (Bloom, 1956). For instance, an instructional strategy included active organizers where a student labels parts of an object. The instructional media associated with this instructional strategy was word processing and involved having the students label a diagram. 
Table 14

Bloom’s Taxonomy and Association of Instructional Strategy and Instructional Media

\begin{tabular}{cccccc}
\hline \multicolumn{2}{c}{ Bloom's Taxonomy of Educational Objectives } & \multicolumn{3}{c}{ Examples from Web-based Units } \\
Domain Level $=$ & Learner Action $=$ & $\begin{array}{c}\text { Action Verb }= \\
\text { Instructional Strategy }=\end{array}$ & $\begin{array}{c}\text { IM }= \\
\text { Sample task }\end{array}$ \\
\hline Knowledge & Recall content & Identify & Active organizers & $\begin{array}{c}\text { Word } \\
\text { Processing }\end{array}$ & $\begin{array}{l}\text { Label parts of } \\
\text { an object on } \\
\text { handout. }\end{array}$ \\
\hline
\end{tabular}

To maintain uniformity when coding instructional strategies and instructional media found in web-based units of the intensity sample, a taxonomy based on Bloom's (1956) taxonomy was developed to assist in assigning a cognitive level associated with the IM in select lessons. This customized taxonomy included columns for domains of learning, learner action, instructional strategies, and examples of the associated IM found in the web-based unit (Table 15). A comprehensive sweep of five lessons in each participant's web-based unit was completed so that each IM in each lesson was reviewed, and assigned a numerical rank from 1 (low) to 6 (high), representing the 6 levels of learning on the customized taxonomy. The resulting rank represented the level of learning that the instructional media addressed. 


\section{Table 15}

\section{Bloom’s Taxonomy: Customized}

\begin{tabular}{|c|c|c|c|}
\hline Bloom's Level & Learner Action & Action Verb/ IS & Task/IM \\
\hline $\begin{array}{l}\text { Knowledge } \\
\text { Level } 1 \\
\text { (low) }\end{array}$ & $\begin{array}{l}\text { Recall content in the exact } \\
\text { form that it was presented. } \\
\text { Memorization of definitions, } \\
\text { formulas, or procedures are } \\
\text { examples of knowledge-level } \\
\text { functioning. }\end{array}$ & $\begin{array}{l}\text { List, define, label, identify, } \\
\text { name. } \\
\text { - active organizers } \\
\text { - information retrieval }\end{array}$ & $\begin{array}{l}\text { Define or label parts of an } \\
\text { object. Concept mapping, } \\
\text { Venn diagrams, KWL charts. } \\
\text { View teacher demonstrations } \\
\text { and presentations. Drill \& } \\
\text { practice, CAI. }\end{array}$ \\
\hline $\begin{array}{c}\text { Comprehension } \\
\text { Level } 2\end{array}$ & $\begin{array}{l}\text { Restate material in their own } \\
\text { words, or can recognize } \\
\text { previously unseen examples } \\
\text { of a concept. }\end{array}$ & $\begin{array}{l}\text { Describe, associate, } \\
\text { categorize, summarize. } \\
\text { active responding } \\
\text { - information retrieval } \\
\text { - whole group instruction or } \\
\text { demonstration } \\
\text { peer-mediated activity } \\
\text { (pm) } \\
\text { - whole group (wg) }\end{array}$ & $\begin{array}{l}\text { Given a list of examples, fill } \\
\text { in worksheet, vocabulary } \\
\text { puzzle. Virtual tour, chats, } \\
\text { writing/journaling. } \\
\text { (wg)Participate in group } \\
\text { discussion: view video, or } \\
\text { presentation } \\
\text { (pm)Take an instructional or } \\
\text { advisory role; respond to } \\
\text { posting on discussion boards, } \\
\text { listservs, chats, emails. }\end{array}$ \\
\hline $\begin{array}{l}\text { Application } \\
\text { Level } 3\end{array}$ & $\begin{array}{l}\text { Apply rules to a problem, } \\
\text { without being given the rule } \\
\text { or formula for solving the } \\
\text { problem. }\end{array}$ & $\begin{array}{l}\text { Apply, calculate, illustrate, } \\
\text { solve. } \\
\text { - problem solving (ps) } \\
\text { - open lab } \\
\text { - hands-on/manipulatives }\end{array}$ & $\begin{array}{l}\text { (ps)- looking for a pattern; } \\
\text { draw a diagram, } \\
\text { storyboarding, writing, } \\
\text { desktop publishing, } \\
\text { simulations, learn by doing. }\end{array}$ \\
\hline $\begin{array}{l}\text { Analysis } \\
\text { Level } 4\end{array}$ & $\begin{array}{l}\text { Break complex concepts or } \\
\text { situations down into their } \\
\text { component parts, and analyze } \\
\text { how the parts are related to } \\
\text { one another. }\end{array}$ & $\begin{array}{l}\text { Analyze, compare, separate, } \\
\text { order, explain. } \\
\text { - Internet Access } \\
\text { - research (r) } \\
\text { - inquiry }\end{array}$ & $\begin{array}{l}\text { (r) - search strategies, } \\
\text { inquiry, collect information } \\
\text { and analyze data. }\end{array}$ \\
\hline $\begin{array}{l}\text { Synthesis } \\
\text { Level } 5\end{array}$ & $\begin{array}{l}\text { Rearrange component parts } \\
\text { to form a new whole. }\end{array}$ & $\begin{array}{l}\text { Combine, modify, rearrange, } \\
\text { create, "what-if". } \\
\text { • student presentation } \\
\text { • problem-solving }\end{array}$ & $\begin{array}{l}\text { Desktop publishing, } \\
\text { authoring/multimedia, } \\
\text { student presentations, video } \\
\text { development }\end{array}$ \\
\hline $\begin{array}{l}\text { Level } 6 \\
\text { (High) }\end{array}$ & $\begin{array}{l}\text { Evaluate or make judgments } \\
\text { on the worth of a concept, } \\
\text { object, etc. for a purpose. }\end{array}$ & $\begin{array}{l}\text { Assess, decide, grade, } \\
\text { recommend, explain, judge } \\
\text { - student presentation } \\
\text { - problem-solving }\end{array}$ & $\begin{array}{l}\text { Peer-mediated, video } \\
\text { development, desktop or } \\
\text { online publishing, authoring/ } \\
\text { multimedia, student } \\
\text { presentations, bookmaking, } \\
\text { e-books, web page or web } \\
\text { site development, } \\
\text { newsletters, newscasts, social } \\
\text { or community } \\
\text { education/presentation. }\end{array}$ \\
\hline
\end{tabular}

\begin{tabular}{ll}
\hline IS Key & Writing/journaling \\
& Problem Solving \\
& Inquiry \\
& Research \\
& Peer Mediated \\
& Student Presentation
\end{tabular}

wj
ps
I
r
pm
sp

Advanced Organizer

Whole Group

Teacher Demo ao

Hands-on/Manipulatives

Active Responding

wg

td

$\mathrm{hm}$

Student Presentation sp 
The activity that was associated with Bloom’s (1956) learner action and action verb was placed in the final column along with the instructional media that best fit Bloom's descriptions and actions. This approach was used to develop a taxonomy that would associate instructional strategies with specific integrated instructional media at specific cognitive levels.

Each unit was reviewed for instructional media and associated strategies. Notes were made during the review process using Acrobat's Note Tool. All notes were embedded with the units and accessible for subsequent reviews, if needed, by using the Comments tab of Acrobat. Extant data from previous lesson sweeps by project evaluators did not indicate which IS was associated with a specific IM. It therefore became necessary to resweep all lessons to locate instructional media, determine the instructional strategy associated with the instructional media, and then rank each IM according to the customized taxonomy. This procedure provided significant new data in that every IM was linked to the way in which it was used.

Lesson Sweep. To determine the level of learning and ways in which instructional media were integrated into web-based learning, instructional strategies associated with those IM that were integrated into each of the nine units were recorded. Individual review tables were used to locate IM in each lesson and then to assign a numerical rank using the customized taxonomy. Some of the units had as many as 10 lessons. Although the whole unit was captured, for uniformity in tabulation, only the first five lessons were reviewed for the study. Completed review matrices (Appendix D) from comprehensive lesson sweeps indicating each IM and associated IS per lesson, per unit were saved to the participant’s folder along with their captured web site. 
The customized taxonomy, which identified levels of Bloom’s Taxonomy with instructional strategies and instructional media, guided the ranking of levels of learning associated with the instructional media along progressively more advanced levels of higher order thinking. Results for the ranking on Bloom's taxonomy of 1 to 6 for each IM integrated in each of the five lessons are represented in Table 16.

\section{Table 16}

IM and Numerical Rank Based on Bloom’s Customized Taxonomy

\begin{tabular}{|c|c|c|c|c|c|c|c|c|c|c|c|}
\hline $\begin{array}{c}\text { CAI/ } / \\
\text { DP }\end{array}$ & $\begin{array}{c}\text { Sim/ } \\
\text { Game }\end{array}$ & $\begin{array}{l}\text { Word } \\
\text { Proc. }\end{array}$ & IR & IA & Email & BB & $\begin{array}{c}\mathbf{A} / \\
\mathbf{M} \mathbf{M}\end{array}$ & DTP & EP & Video & $\begin{array}{c}\text { Open } \\
\text { Lab }\end{array}$ \\
\hline 2 & 4 & 1 & 5 & 2 & 3 & 2 & 4 & 5 & 1 & 2 & 4 \\
\hline 2 & 1 & 1 & 3 & 1 & 2 & 2 & 5 & 5 & 1 & 1 & 3 \\
\hline 2 & 1 & 1 & 3 & 2 & 2 & & 5 & 5 & 1 & 1 & 1 \\
\hline 1 & 5 & 1 & 3 & 6 & 6 & & 6 & & 1 & 1 & \\
\hline 2 & 3 & 1 & 2 & 2 & 5 & & & & 1 & 1 & \\
\hline 2 & & 1 & 2 & 2 & 2 & & & & 1 & 1 & \\
\hline 5 & & 5 & 1 & 2 & 5 & & & & 1 & 1 & \\
\hline 2 & & 1 & 1 & 2 & & & & & 1 & 1 & \\
\hline 2 & & 1 & 5 & 2 & & & & & 2 & 1 & \\
\hline 3 & & 2 & 2 & 2 & & & & & 1 & 1 & \\
\hline 1 & & 5 & 1 & 1 & & & & & 6 & 1 & \\
\hline \multirow[t]{30}{*}{4} & & 1 & 1 & 2 & & & & & 1 & 1 & \\
\hline & & 1 & 2 & 2 & & & & & 2 & 5 & \\
\hline & & 1 & 3 & 4 & & & & & 1 & 4 & \\
\hline & & 1 & 4 & 2 & & & & & 1 & 4 & \\
\hline & & 1 & 5 & 1 & & & & & 1 & 6 & \\
\hline & & 1 & 5 & 1 & & & & & 1 & & \\
\hline & & 1 & 3 & 1 & & & & & 1 & & \\
\hline & & 1 & 3 & 1 & & & & & 2 & & \\
\hline & & 1 & 3 & 1 & & & & & 1 & & \\
\hline & & 1 & & 1 & & & & & 5 & & \\
\hline & & 1 & & 1 & & & & & 5 & & \\
\hline & & 1 & & 1 & & & & & 4 & & \\
\hline & & 2 & & 1 & & & & & 1 & & \\
\hline & & 5 & & 1 & & & & & 4 & & \\
\hline & & 3 & & 1 & & & & & 3 & & \\
\hline & & 2 & & 5 & & & & & & & \\
\hline & & 4 & & 1 & & & & & & & \\
\hline & & 4 & & 1 & & & & & & & \\
\hline & & 1 & & 1 & & & & & & & \\
\hline & & 2 & & 1 & & & & & & & \\
\hline & & 1 & & 1 & & & & & & & \\
\hline & & 4 & & 1 & & & & & & & \\
\hline & & 2 & & 1 & & & & & & & \\
\hline & & 2 & & 2 & & & & & & & \\
\hline & & 2 & & 1 & & & & & & & \\
\hline & & 2 & & 4 & & & & & & & \\
\hline & & 1 & & 1 & & & & & & & \\
\hline & & 2 & & 4 & & & & & & & \\
\hline & & 1 & & & & & & & & & \\
\hline & & 2 & & & & & & & & & \\
\hline
\end{tabular}


Each IM in each lesson received a numerical rank that corresponded with a level of learning on Bloom's Taxonomy. Table 17 shows the total number of times the IM were integrated into the lessons. There were 178 incidences of the integration of an IM in the 5 lessons for each of the 9 units. The table illustrates, for example, that the most frequently used IM was word processing (41), followed by Internet access (39), PowerPoint (26), and information retrieval (20). The mode shows that the most frequently occurring rank level of each of these four IM was Level 1, Knowledge. These media were most frequently used to recall information, memorize procedures, label parts of a diagram, or for teacher demonstrations.

Video, which was integrated 16 times, was most frequently used at Level 1 on Bloom's taxonomy. Teachers used video to demonstrate a concept or to present content. Computer-aided instruction/drill practice, integrated 12 times, was most frequently used at Level 2 on Bloom's taxonomy, Comprehension. At this level, when CAI/drill and practice is integrated, students are actively responding to virtual chats, filling in worksheets, completing vocabulary puzzles and participating in whole group discussions. Table 17

Instructional Media, Total Number of Times Used, and Mode: Bloom’s Rank

\begin{tabular}{|c|c|c|c|c|c|c|c|c|c|c|c|c|c|}
\hline & CAI & Sim & WP & IR & IA & Em & BB & $\mathbf{A} / \mathbf{M}$ & DTP & EP & $\mathbf{V}$ & OL & Total \\
\hline \# Xs Used & 12 & 5 & 41 & 20 & 39 & 7 & 2 & 4 & 3 & 26 & 16 & 3 & 178 \\
\hline Mode & 2 & 1 & 1 & 1 & 1 & 2 & 2 & 5 & 5 & 1 & 1 & $1,3,4, * *$ & \\
\hline
\end{tabular}

With 7 incidences of use, email was most frequently integrated at Level 2 on Bloom's taxonomy, Comprehension. Email tasks at Level 2 included participating in chats, and student-to-student communication about class assignments. 
Simulations/educational games were integrated five times, and most frequently at Level 1 on Bloom's taxonomy. Level 1 examples would be a simulation task that only requires the student to navigate a simulation or describe the simulation.

Authoring and multimedia development was integrated four times while desktop publishing was integrated three times. Although incidences of integration of these instructional media were low, they were each most frequently integrated at Level 5 on Bloom's taxonomy. At Level 5 students are problem solving; rearranging component parts to form a whole, modifying, and creating products. Open lab was integrate three times, once at Level 1, once at Level 3, and once at Level 4. Open lab at Level 1 (Knowledge) included retrieving information or downloading files from the Internet. Level 3 (Application), involved problem solving, storyboarding, and journaling. Tasks associated with Level 4 (Analysis) included doing research over the Internet, performing searches, and analyzing data. There were two incidences where students posted information to a Bulletin Board. Level 2, Comprehension, is associated with Bulletin Boards and involved participating in a group discussion, and restating information in their own words.

Although many of the participants integrated IM at levels ranging from 1 to 6 on Bloom's taxonomy, the most frequently occurring rank of each IM will illustrate the level of learning that the IM address most frequently. Table 17 illustrates that when integrated, information retrieval, word processing, Internet access, electronic presentations, video, simulations, and open lab access were associated with Level 1, Knowledge, on Bloom’s taxonomy. Computer-aided instruction/drill and practice, email, and bulletin boards were most frequently integrated at Level 2, Comprehension, on Bloom’s taxonomy. Open lab 
access, when integrated, addressed Levels 1, 3, and 4 (Knowledge, Comprehension, and Analysis) on Bloom’s taxonomy. Authoring/ multimedia development and desktop publishing when integrated, were most frequently associated with Level 5, Synthesis, on Bloom's taxonomy.

Seven instructional media were most frequently integrated at Level 1 on Bloom’s taxonomy, Knowledge, and three instructional media were most frequently integrated at Level 2, Comprehension. These 10 instructional media exhibited the highest incidences of use, and when integrated, most frequently addressed low levels of learning. The remaining instructional media (authoring/multimedia development, desktop publishing, and open lab access), although integrated less frequently than the other 10 instructional media, were integrated at higher levels according to Bloom's taxonomy. Of all the IM integrated in the lessons reviewed, while the most frequently occurring level of learning was knowledge followed by comprehension, some IM were integrated at high levels of learning (application, analysis, and synthesis).

The participants integrated the greatest number of instructional media at Level 1 , the Knowledge level. The types of IM participants integrated at Level 1 included simulations, word processing information retrieval, electronic presentations, video development, and open lab access. The types of instructional media that participants integrated at Level 2, (Comprehension) included CAI/drill and practice, email, and bulletin board access. Other media (desktop publishing and authoring/multimedia development), although integrated at higher levels, were not integrated frequently at these levels, and therefore a conclusion associated with the cognitive level of learning cannot be made. 
Research Question 5: Is There a Correlation Between Types and Use of Instructional Media and Cognitive Levels of Learning?

The intensity sampling selected for RQ 4 was used to explore the correlation between types and use of instructional media and cognitive levels of learning. Instructional media, those that were indicated by lesson sweep analysis as being present in the lessons, were used as guidelines to match the IM with the action verbs that represent intellectual activity at a specific classification level on Tomei’s (2001) instructional technology taxonomy. Tomei’s taxonomy consists of six interconnected levels that vary in complexity from low to high: literacy, communication, decisionmaking, instruction, integration, and acculturation. Tomei based his six levels of taxonomy classification on Bloom's (1956) six levels of educational objectives. A comparison of the taxonomies showed that several action verbs were common to each taxonomy (Chapter 2, Table 3). Actual examples found in the units from comprehensive lesson sweeps that illustrated specific instructional strategies and their association with the instructional media were used to align domain levels, learner actions, and activities.

Coding the IM for intellectual activity according to Tomei’s (2001) instructional technology taxonomy was accomplished using the same strategy as the coding for the IM for RQ 4 when using Bloom's (1956) taxonomy. Coding was based on IM examples and their integrations found to be present in web-based units of Trek 21 participants during the comprehensive review of units. As an example, Table 18 illustrates the association of word processing to domain levels, learner action, action verbs, instructional strategies and sample tasks on both taxonomies. 
Table 18

Bloom’s and Tomei’s Taxonomies with Instructional Strategies and Instructional Media

\begin{tabular}{|c|c|c|c|c|c|c|}
\hline \multicolumn{4}{|c|}{$\underline{\text { Taxonomy Descriptors }}$} & \multicolumn{3}{|c|}{ Examples from Web-based Units } \\
\hline Taxonomy & Domain/Level & Learner Action & Action Verb & Instructional Strategy & IM & Sample task \\
\hline Bloom & Knowledge/1 & Recall content & Identify & Active organizers & $\begin{array}{c}\text { Word } \\
\text { Processing }\end{array}$ & $\begin{array}{l}\text { Label parts } \\
\text { of an object } \\
\text { on handout. }\end{array}$ \\
\hline Tomei & Literacy/1 & Keyboarding & Use & Active organizers & $\begin{array}{c}\text { Word } \\
\text { Processing }\end{array}$ & $\begin{array}{l}\text { Fill in blanks } \\
\text { or click and } \\
\text { drag labeling } \\
\text { information }\end{array}$ \\
\hline
\end{tabular}

To maintain uniformity when coding instructional media found in web-based units during the comprehensive review, examples of the integrated IM and associated strategies were added to Tomei’s instructional technology taxonomy as they were encountered when reviewing each lesson. For example, in the first lesson reviewed for the intensity sample the first IM encountered was computer-aided instruction/drill and practice. The task in the lesson required that the students download and complete a KWL (Know, Want to Know, Learned) chart. The IM was word processing, the product was a KWL chart, and the associated instructional strategy was advanced organizer. This IM was coded as Level 1 on each taxonomy. Every IM was assigned a numerical rank according to the associated level on Tomei's instructional technology taxonomy. This coding strategy continued with each occurrence of a new example being noted in the proper category and cell (Table 19) on Tomei's instructional technology taxonomy. The resulting rank represented the intellectual activity associated with the IM. 


\section{Table 19}

\section{Tomei’s Instructional Technology Taxonomy: Customized}

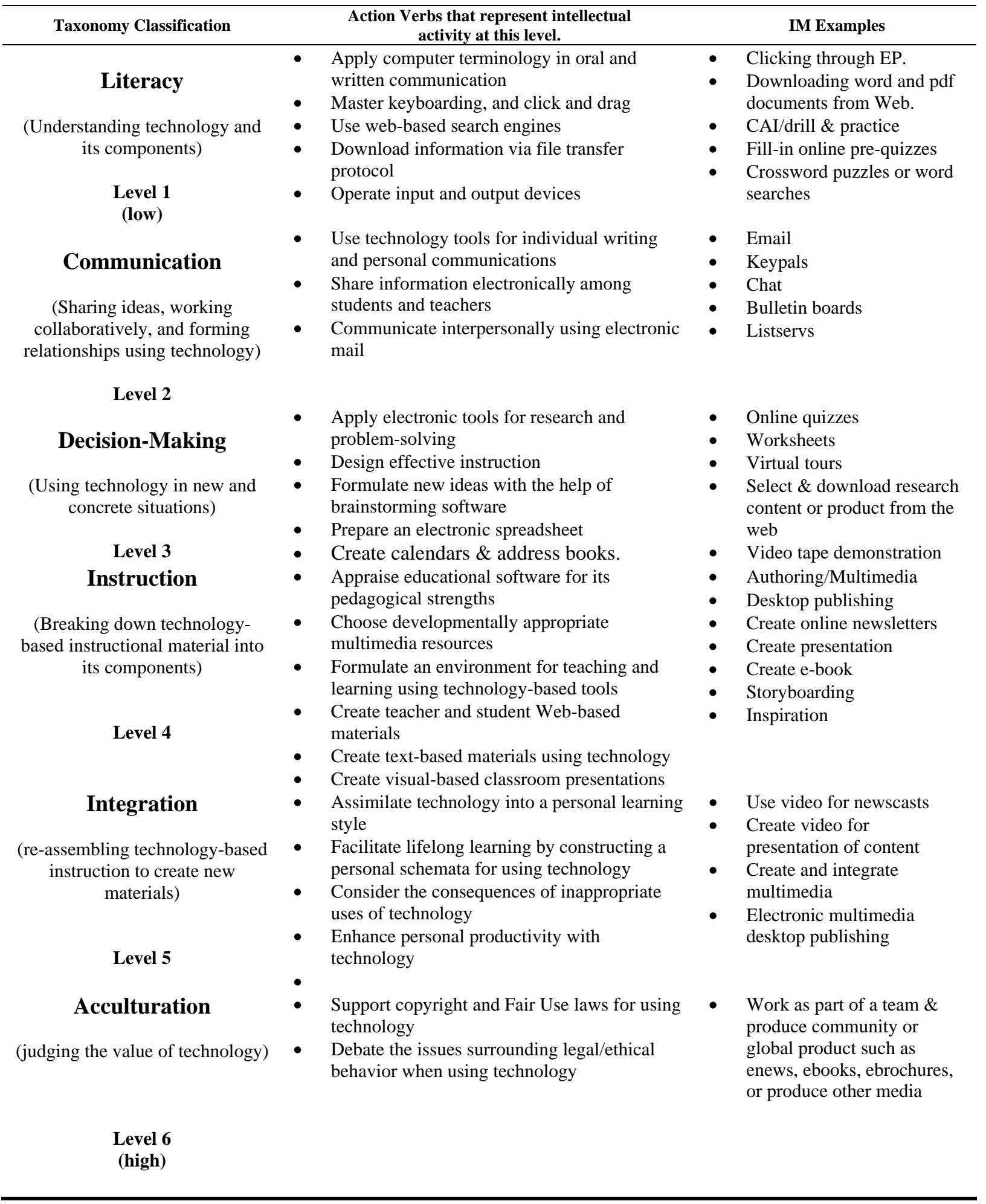


Lesson Sweep. To examine the correlation between types and use of instructional media and the cognitive levels of learning, instructional media associated with those instructional strategies that were integrated into each of the nine units were recorded in individual review matrices (Appendix D, p. 105). Completed matrices indicating each instructional media and associated instructional strategy per lesson, per unit were saved to the participant's folder along with his/her captured site.

This customized instructional technology taxonomy (Table 18) guided the ranking of levels of intellectual activity associated with the integration of instructional media along progressively more advanced levels of higher order thinking. Results for the ranking on Tomei’s instructional technology taxonomy of 1 to 6 for each IM integrated in each of the five lessons are represented in Table 20. 
Table 20

IM and Numerical Value According to Tomei’s Instructional Technology Taxonomy

\begin{tabular}{|c|c|c|c|c|c|c|c|c|c|c|c|}
\hline $\begin{array}{c}\text { CAI/ } \\
\text { DP }\end{array}$ & $\begin{array}{l}\text { Sim/ } \\
\text { Game }\end{array}$ & $\begin{array}{l}\text { Word } \\
\text { Proc. }\end{array}$ & IR & IA & Email & BB & $\begin{array}{c}\text { A/ } \\
\text { MM }\end{array}$ & DTP & PPT & Video & $\begin{array}{c}\text { Open } \\
\text { Lab }\end{array}$ \\
\hline 1 & 3 & 1 & 3 & 1 & 2 & 2 & 5 & 4 & 1 & 1 & 3 \\
\hline 1 & 1 & 1 & 3 & 1 & 3 & 2 & 4 & 4 & 1 & 1 & 3 \\
\hline 1 & 1 & 1 & 3 & 3 & 3 & & 6 & 4 & 1 & 1 & 1 \\
\hline 1 & 3 & 2 & 1 & 3 & 2 & & 5 & & 1 & 1 & \\
\hline 1 & 2 & 1 & 1 & 1 & 5 & & & & 1 & 1 & \\
\hline 1 & & 1 & 1 & 1 & 3 & & & & 1 & 1 & \\
\hline 3 & & 3 & 1 & 1 & 5 & & & & 1 & 1 & \\
\hline 1 & & 0 & 1 & 1 & & & & & 1 & 1 & \\
\hline 1 & & 1 & 3 & 1 & & & & & 2 & 1 & \\
\hline 0 & & 1 & 3 & 1 & & & & & 1 & 1 & \\
\hline 1 & & 4 & 3 & 1 & & & & & 5 & 1 & \\
\hline \multirow[t]{30}{*}{1} & & 1 & 3 & 1 & & & & & 1 & 1 & \\
\hline & & 1 & 1 & 1 & & & & & 1 & 4 & \\
\hline & & 1 & 2 & 3 & & & & & 1 & 4 & \\
\hline & & 1 & 1 & 1 & & & & & 1 & 4 & \\
\hline & & 1 & 4 & 1 & & & & & 1 & 5 & \\
\hline & & 1 & 4 & 1 & & & & & 1 & & \\
\hline & & 1 & 3 & 1 & & & & & 4 & & \\
\hline & & 1 & 3 & 1 & & & & & 3 & & \\
\hline & & 1 & 3 & 1 & & & & & 1 & & \\
\hline & & 1 & & 1 & & & & & 4 & & \\
\hline & & 1 & & 1 & & & & & 5 & & \\
\hline & & 1 & & 1 & & & & & 4 & & \\
\hline & & 1 & & 1 & & & & & 1 & & \\
\hline & & 4 & & 1 & & & & & 3 & & \\
\hline & & 4 & & 5 & & & & & 3 & & \\
\hline & & 3 & & 5 & & & & & & & \\
\hline & & 1 & & 1 & & & & & & & \\
\hline & & 1 & & 1 & & & & & & & \\
\hline & & 1 & & 1 & & & & & & & \\
\hline & & 1 & & 1 & & & & & & & \\
\hline & & 1 & & 1 & & & & & & & \\
\hline & & 4 & & 1 & & & & & & & \\
\hline & & 1 & & 1 & & & & & & & \\
\hline & & 1 & & 3 & & & & & & & \\
\hline & & 1 & & 1 & & & & & & & \\
\hline & & 1 & & 1 & & & & & & & \\
\hline & & 1 & & 1 & & & & & & & \\
\hline & & 1 & & 5 & & & & & & & \\
\hline & & 1 & & & & & & & & & \\
\hline & & 3 & & & & & & & & & \\
\hline
\end{tabular}


Each IM in each lesson received a numerical rank that corresponded with a level of intellectual activity associated with the use of the IM on Tomei’s taxonomy. Table 21 summarizes all levels that the IM addressed, regardless of the number of times used, according to Bloom's and to Tomei's taxonomies. Authoring/multimedia development was integrated at level six (highest level) on each taxonomy which demonstrates the potential of this IM to address higher order thinking. CAI, simulations/educational games, word processing, information retrieval, email, authoring/multimedia development, electronic presentations, and video were all integrated at high levels on at least one of the taxonomies which demonstrates the potential of these IM to address high levels of learning when integrated in the manner associated with the levels on each domain.

\section{Table 21}

IM and Level of Integration on Bloom’s and Tomei’s Taxonomies

\begin{tabular}{|c|c|c|c|c|c|c|c|c|c|c|c|c|c|c|c|c|c|c|c|c|c|c|c|c|}
\hline & \multicolumn{2}{|c|}{ CAI } & \multicolumn{2}{|c|}{ SIM } & \multicolumn{2}{|c|}{ WP } & \multicolumn{2}{|c|}{ IR } & \multicolumn{2}{|c|}{ IA } & \multicolumn{2}{|c|}{ Em } & \multicolumn{2}{|c|}{ BB } & \multicolumn{2}{|c|}{$\mathbf{A} / \mathbf{M}$} & \multicolumn{2}{|c|}{ DTP } & \multicolumn{2}{|c|}{ EP } & \multicolumn{2}{|c|}{ V } & \multicolumn{2}{|c|}{ OL } \\
\hline Level & B & $\mathrm{T}$ & B & $\mathrm{T}$ & B & $\mathrm{T}$ & B & $\mathrm{T}$ & B & $\mathrm{T}$ & B & $\mathrm{T}$ & B & $\mathrm{T}$ & B & $\mathrm{T}$ & B & $\mathrm{T}$ & B & $\mathrm{T}$ & B & $\mathrm{T}$ & B & $\mathrm{T}$ \\
\hline 1 & $\checkmark$ & $\checkmark$ & $\sqrt{ }$ & $\checkmark$ & $\checkmark$ & $\checkmark$ & $\sqrt{ }$ & $\sqrt{ }$ & $\checkmark$ & $\sqrt{ }$ & & $\checkmark$ & & & & & & & $\checkmark$ & $\checkmark$ & $\checkmark$ & $\checkmark$ & $\checkmark$ & $\checkmark$ \\
\hline 2 & $\checkmark$ & & & $\checkmark$ & $\checkmark$ & $\checkmark$ & $\checkmark$ & $\sqrt{ }$ & $\checkmark$ & $\checkmark$ & $\sqrt{ }$ & & $\checkmark$ & $\checkmark$ & & & & & $\checkmark$ & $\checkmark$ & $\checkmark$ & & & \\
\hline 3 & & $\checkmark$ & $\sqrt{ }$ & $\checkmark$ & $\checkmark$ & $\checkmark$ & $\checkmark$ & $\sqrt{ }$ & & & $\checkmark$ & $\checkmark$ & & & & & & & $\sqrt{ }$ & $\checkmark$ & $\checkmark$ & & $\checkmark$ & $\checkmark$ \\
\hline 4 & $\checkmark$ & & $\sqrt{ }$ & & $\checkmark$ & $\checkmark$ & $\checkmark$ & $\sqrt{ }$ & $\checkmark$ & & & & & & $\checkmark$ & $\checkmark$ & $\sqrt{ }$ & $\checkmark$ & $\checkmark$ & $\checkmark$ & $\checkmark$ & $\sqrt{ }$ & $\checkmark$ & \\
\hline 5 & $\checkmark$ & & $\sqrt{ }$ & & $\checkmark$ & & $\checkmark$ & & $\checkmark$ & $\checkmark$ & $\checkmark$ & $\checkmark$ & & & $\checkmark$ & $\checkmark$ & $\checkmark$ & $\checkmark$ & $\checkmark$ & $\checkmark$ & $\checkmark$ & $\checkmark$ & & \\
\hline 6 & & & & & & & & & $\checkmark$ & & $\checkmark$ & & & & $\checkmark$ & $\checkmark$ & & & $\checkmark$ & & $\checkmark$ & & & \\
\hline & & & & & & & & & & & & & & & & & & & & & & & & \\
\hline
\end{tabular}

$\mathrm{B}=$ Bloom's Taxonomy

$\mathrm{T}=$ Tomei's Taxonomy

Table 22 shows the total number of times the IM were integrated into the lessons. There were 178 incidences of the integration of an IM in the 5 lessons from each of the 9 units. The table illustrates that the most frequently used IM was word processing (WP), followed by Internet access (IA), electronic presentations (EP), and information retrieval (IR). The mode shows that the most frequently occurring rank level of word processing 
and Internet access was Level 1, Literacy. When word processing was integrated at this level, the students, for example, used keyboarding skills, operated input and output devices, and used web-based search engines. Internet access was most frequently integrated at Level 1, Literacy, on Tomei’s taxonomy. Students accessed the Internet to download information, and to fill in online puzzles or quizzes.

Table 22

Instructional Media, Total Number of Times Used, and Mode: Tomei's Rank

\begin{tabular}{cccccccccccccc}
\hline & CAI & Sim & WP & IR & IA & Em & BB & A/M & DTP & EP & V & OL & total \\
\hline $\begin{array}{c}\text { \# of } \\
\text { times used }\end{array}$ & 12 & 5 & 41 & 20 & 39 & 7 & 2 & 4 & 3 & 26 & 16 & 3 & $\mathbf{1 7 8}$ \\
Mode & 1 & $1,3^{*}$ & 1 & 3 & 1 & $2,5^{*}$ & 2 & 5 & 4 & 1 & 1 & 3 & \\
\hline * Bimodal & & & & & & & & & & & & &
\end{tabular}

Other IM that were most frequently integrated at the Literacy level on Tomei’s taxonomy included electronic presentation and video development. These two IM were most frequently used to deliver content. The students clicked through electronic presentations or watched a video. Computer-aided instruction, drill and practice were most frequently integrated at the literacy level. Students used the computer to take a quiz or navigate an electronic presentation. Bulletin boards were most frequently used at Level 2 on Tomei's taxonomy; students share information. Email was bimodal. Email was most frequently used at Levels 2 and 5 (communication and integration). Students exchanged information at Level 2, but at Level 5 students created new materials and considering appropriate uses of technology.

Open lab was most frequently used for decision-making, Level 3 on Tomei’s taxonomy. On this level, students were brainstorming and using software. Information retrieval was most frequently integrated at Level 3 on Tomei’s taxonomy, decision- 
making. At Level 3, students were using instructional technology in new ways by applying electronic tools for research and problem-solving. IM examples associated with this level included downloading research content from the web. Simulations/educational games were bimodal and were most frequently used on both Level 1 and Level 3, literacy and decision-making.

Table 23

Integration of Instructional Media and Most Frequently Addressed Level on Taxonomies

\begin{tabular}{rccccccccccccc}
\hline & CAI & Sim & WP & IR & IA & Em & BB & A/M & DTP & EP & V & OL & Total \\
\hline $\begin{array}{r}\text { Number of } \\
\text { times used }\end{array}$ & 12 & 5 & 41 & 20 & 39 & 7 & 2 & 4 & 3 & 26 & 16 & 3 & \\
Bloom & 2 & 1 & 1 & 1 & 2 & 2 & 5 & 5 & 1 & 1 & 1 & $1,3,4$ & \\
Tomei & 1 & $1,3^{*}$ & 1 & 3 & 1 & $2,5^{*}$ & 2 & 5 & 4 & 1 & 1 & 3 & \\
\hline
\end{tabular}

\footnotetext{
* Bimodal
}

** Trimodal

Table 23 compares the number of instructional media that were integrated in the lessons of the units at Bloom/Tomei modes. The table illustrates that word processing, electronic presentations, video, and simulations/educational games were most frequently integrated at Level 1 on Bloom’s taxonomy and on Tomei’s taxonomy. The IM, word processing, was most frequently integrated at the literacy level (Tomei’s Taxonomy) and used at the knowledge level (Bloom's Taxonomy). Authoring/multimedia development was most frequently integrated at the synthesis level on Tomei’s taxonomy and used on the integration level of Bloom's taxonomy.

Of the IM integrated in these lessons that have sufficient frequencies of integration to have a clearly defined mode where $n$ is at least as large as the range (Glass \& Hopkins, 1996), the integration of all but three IM show a correlation between the 
taxonomies. Computer-aided instruction/drill and practice, information retrieval, and Internet access do not show an identical relationship with their level of use. However, when integrated a sufficient number of times, more than 6 times in this study, there is a correlation between the types and use of instructional media and levels of learning. When an IM was integrated at a specific level on one taxonomy, the IM correlated with that level on the other taxonomy four out of seven times (Table 24).

Table 24

Correlation of IM and Taxonomies’ Levels

\begin{tabular}{|c|c|c|c|c|c|c|c|c|c|c|c|c|}
\hline & CAI & $\operatorname{Sim} \bullet$ & WP & IR & IA & Em & $\mathrm{BB} \bullet$ & $\mathrm{A} / \mathrm{M} \bullet$ & DTP • & EP & $\mathbf{V}$ & $\mathrm{OL} \bullet$ \\
\hline $\begin{array}{c}\text { \# of } \\
\text { times used }\end{array}$ & $12 \bullet$ & & 41 & $20 \bullet$ & $39 \bullet$ & 7 & & & & 26 & 16 & \\
\hline $\begin{array}{l}\text { Bloom } \\
\text { Mode }\end{array}$ & 2 & & 1 & 1 & 2 & 2 & & & & 1 & 1 & \\
\hline $\begin{array}{l}\text { Tomei } \\
\text { Mode }\end{array}$ & 1 & & 1 & 3 & 1 & $2,5^{*}$ & & & & 1 & 1 & \\
\hline
\end{tabular}

* Bimodal

- Integration number too low.

$\bullet$ Levels do not correlate

Based on the findings of where specific instructional media were most frequently integrated into the lessons of the intensity sampling, Table 25 illustrates where these IM were classified according to their integration. The table illustrates that there were more IM associated with Level 1 on each taxonomy, and that IM were less frequently integrated to address higher levels of learning. The table classifies IM according to the most frequently associated level of integration by the participants. 
Table 25

Classification of IM According to Most Frequently Associated Level of Integration

\begin{tabular}{|c|c|c|c|}
\hline & Bloom Action Verbs & Integrated IM & Tomei Action Verbs \\
\hline $\begin{array}{c}\text { High } \\
\text { Level } 6\end{array}$ & $\begin{array}{l}\text { Evaluation } \\
\text { - } \text { appraise, argue, } \\
\text { assess, choose, } \\
\text { judge, evaluate }\end{array}$ & - $\quad$ Desktop Pub. & $\begin{array}{l}\text { Acculturation } \\
\text { - } \quad \text { support, debate }\end{array}$ \\
\hline Level 5 & $\begin{array}{l}\text { Synthesis } \\
\qquad \quad \text { arrange, prepare, } \\
\text { compose, } \\
\text { construct, create }\end{array}$ & $\begin{array}{ll}\text { - } & \text { Authoring/ } \\
\text { Multimedia Dev. } \\
\text { - } \\
\text { - } & \text { Eesktop Pub. }\end{array}$ & $\begin{array}{l}\text { Integration } \\
\qquad \text { assimilate, } \\
\text { facilitate, } \\
\text { consider, } \\
\text { enhance }\end{array}$ \\
\hline Level 4 & $\begin{array}{l}\text { Analysis } \\
\qquad \text { calculate, } \\
\text { compare, } \\
\text { examine, contrast }\end{array}$ & - Open Lab & $\begin{array}{l}\text { Instruction } \\
\text { - appraise, choose, } \\
\text { create, formulate }\end{array}$ \\
\hline Level 3 & $\begin{array}{l}\text { Application } \\
\text { - apply, choose, } \\
\text { demonstrate, } \\
\text { solve, use }\end{array}$ & $\begin{array}{ll}\text { - } & \text { Open Lab } \\
\text { - } & \text { Simulations/ } \\
\text { Edu. Games } \\
\text { - } & \text { Information } \\
& \text { Retrieval }\end{array}$ & $\begin{array}{l}\text { Decision-making } \\
\text { • } \\
\text { apply, design, } \\
\text { prepare, create, } \\
\text { formulate }\end{array}$ \\
\hline Level 2 & $\begin{array}{l}\text { Comprehension } \\
\bullet \quad \text { classify, } \\
\text { describe, explain, } \\
\text { express, select }\end{array}$ & $\begin{array}{ll}\text { - } & \text { CAI/DP } \\
\text { - } & \text { Email } \\
\text { - } & \text { Bulletin Boards }\end{array}$ & $\begin{array}{l}\text { Communications } \\
\bullet \quad \text { use, share, } \\
\text { communicate }\end{array}$ \\
\hline $\begin{array}{c}\text { Low } \\
\text { (Level 1) }\end{array}$ & $\begin{array}{l}\text { Knowledge } \\
\text { - } \quad \text { arrange, define, } \\
\text { list, recognize } \\
\text { state, repeat }\end{array}$ & $\begin{array}{ll}\text { - } & \text { Simulations } \\
\text { - } & \text { Educational } \\
& \text { games } \\
\text { - } & \text { Word processing } \\
\text { - } & \text { Information } \\
& \text { Retrieval } \\
\text { - } & \text { Internet Access } \\
\text { - Electronic } \\
\text { - } \text { Presentations } \\
\text { - Opideo } \\
\text { - CAI/DP }\end{array}$ & $\begin{array}{l}\text { Literacy } \\
\text { • apply, use, } \\
\text { consider, operate, } \\
\text { download master }\end{array}$ \\
\hline
\end{tabular}




\section{In-depth}

To provide a more in-depth look at the integration of instructional media, individuals whose units indicated a high use of instructional media through lesson sweep analysis were selected for an intensity sampling and interviews. Interview data were expected to corroborate results gathered through other methods and to add validity to this study. Participants were asked open-ended questions (Appendix E) relative to their background, behaviors, experiences, opinions, beliefs, and knowledge regarding their teaching and the integration of their web-based unit into an educational environment. This information was sought to examine participants perception of IM usage, which exemplifies practical knowledge (Merriam, 1998).

Procedure. Participants who met the criteria as discussed previously, and who were identified for the intensity sampling were contacted by phone to schedule a day and time for an interview. All interviews were completed within five days and conducted over the phone. All participants agreed to be taped. Before the interview began they were reminded that their identity would be kept secret, that their participation was voluntary, and that the interview was being recorded.

Interviews. A voice-activated tape recorder connected directly to the phone line recorded the interview while the researcher asked questions and wrote notes. Interviews were 30 to 40 minutes in length. After all interviews had been conducted the researcher transcribed interview scripts and combined them in both digital and hard copy with her notes. The digital copy was placed in a folder that contained a copy of the participants web-unit. Digital copies of data allowed hyperlinking and scanning among documents, 
which expedited confirmation of data from multiple sources: web units, sweep results, interview scripts, and researcher's notes.

Coding and Data Analysis. During the initial reading of the transcripts and field notes, perceived general impressions were noted by the researcher. Scripts were read again and notations about responses to particular interview questions and their alignment to research questions were made in the margins. Repeated key words and phrases were highlighted and clusters of like phrases were used as emergent themes. Responses that appeared to have a relationship to the research questions were coded according to the research question (RQ1, RQ2, etc.) and placed in a two-dimensional table for analysis.

A frequency count of recurring key words and associated phrases that seemed to have no direct relationship to specific research revealed 20 phrases of possible importance that were entered into a table (Table 26) for additional analysis. Interview scripts were reread and participants who had exact or similar phrasing of key words were noted in the table with a checkmark. Table 26 illustrates key phrases extracted from the interview scripts and the number of participants whose comments included a reference to the phrase or concept. 
Table 26

Key Words Common to Multiple Interview Responses

\begin{tabular}{rrrrrrrrrrr} 
Keyword(s) & Alice & Bob & Cara & Dora & Edd & Fran & Gina & Hana & Izzy & total \\
\hline Not enough time & $\checkmark$ & $\checkmark$ & $\checkmark$ & $\checkmark$ & $\checkmark$ & $\checkmark$ & $\checkmark$ & $\checkmark$ & $\checkmark$ & $\mathbf{9}$ \\
Used parts of the unit & $\checkmark$ & $\checkmark$ & $\checkmark$ & $\checkmark$ & $\checkmark$ & $\checkmark$ & $\checkmark$ & $\checkmark$ & $\checkmark$ & $\mathbf{9}$ \\
Lab time a concern & $\checkmark$ & & $\checkmark$ & & $\checkmark$ & $\checkmark$ & $\checkmark$ & $\checkmark$ & & $\mathbf{6}$ \\
Unit is supplemental & $\checkmark$ & & $\checkmark$ & & $\checkmark$ & & $\checkmark$ & $\checkmark$ & $\checkmark$ & $\mathbf{6}$ \\
Interactive & $\checkmark$ & & & $\checkmark$ & & $\checkmark$ & $\checkmark$ & & $\checkmark$ & $\mathbf{5}$ \\
Small group instruction & $\checkmark$ & & $\checkmark$ & & $\checkmark$ & $\checkmark$ & $\checkmark$ & & & $\mathbf{5}$ \\
Learned a lot & $\checkmark$ & & $\checkmark$ & $\checkmark$ & & $\checkmark$ & $\checkmark$ & & & $\mathbf{5}$ \\
Grant Money & & & & $\checkmark$ & $\checkmark$ & & $\checkmark$ & $\checkmark$ & & $\mathbf{4}$ \\
Extra practice/review & $\checkmark$ & & & $\checkmark$ & $\checkmark$ & & $\checkmark$ & & & $\mathbf{4}$ \\
Student(s) create/make & & & & & $\checkmark$ & $\checkmark$ & & $\checkmark$ & $\checkmark$ & $\mathbf{4}$ \\
Students work on their own & & & $\checkmark$ & $\checkmark$ & $\checkmark$ & & $\checkmark$ & & & $\mathbf{4}$ \\
IT not appropriate & $\checkmark$ & & $\checkmark$ & $\checkmark$ & & & & $\checkmark$ & & $\mathbf{4}$ \\
Element(s) structured by teacher & $\checkmark$ & & & & & & & $\checkmark$ & $\mathbf{3}$ \\
Limited or not right equipment/IM & & $\checkmark$ & & & & & $\checkmark$ & $\checkmark$ & & $\mathbf{3}$ \\
Teacher does “own thing” & $\checkmark$ & & $\checkmark$ & & & & & $\checkmark$ & & $\mathbf{3}$ \\
Cannot do. Uncomfortable with IM & $\checkmark$ & & $\checkmark$ & & & $\checkmark$ & & & & $\mathbf{3}$ \\
Added to the unit after Trek & & & & & $\checkmark$ & & $\checkmark$ & & $\checkmark$ & $\mathbf{3}$ \\
Practical/Authentic & & & $\checkmark$ & & & & & $\checkmark$ & & $\mathbf{2}$ \\
Not student-centered enough & & $\checkmark$ & & & & & & & $\checkmark$ & $\mathbf{2}$ \\
Unit was teacher-centered & & $\checkmark$ & & $\checkmark$ & & & & & & $\mathbf{2}$
\end{tabular}

General demographics of the nine people selected by the intensity sampling process were discussed in greater detail with RQ 4. The participants represented four counties, various content areas, and grade levels across the three years of the Institute. All nine web-based units developed by the participants selected through the intensity sampling process were captured from the Trek 21 web site (www.trek-21.wvu.edu), downloaded, and reviewed during comprehensive unit sweeps and subsequent analysis. Research Question 1: What types of instructional media do P-12 teachers integrate into web-based learning?

Table 27 displays shortened responses from the transcribed interview scripts of each participant to interview questions that were designed to illicit responses to research questions. The table illustrates the type of instructional media participants said they used. 
Eight of the nine participants said they used PowerPoint, six of whom listed it first, which

illustrates its popularity among teachers.

Table 27

Alignment of Interview Questions to Research Questions

\begin{tabular}{|c|c|c|c|c|c|c|c|c|c|}
\hline & Alice & Bob & Cara & Dora & Edd & Fran & Gina & Hana & Izzy \\
\hline RQ1: Types of IM & $\begin{array}{l}\cdot \text { ppt } \\
\cdot \text { pdf } \\
\cdot \text { Flash }\end{array}$ & $\begin{array}{l}\text { - Internet } \\
\text { - Excel }\end{array}$ & $\begin{array}{l}\text { ppt } \\
\cdot \text { - Word } \\
\text { - Internet }\end{array}$ & $\begin{array}{l}\cdot \text { ppt } \\
\text { - Internet } \\
\text { - Inspir. } \\
\cdot \text { Kids- } \\
\text { piration }\end{array}$ & $\begin{array}{l}\text { - video } \\
\text { - Word } \\
\text { - ppt } \\
\text { - MS pub. } \\
\text {-photodr. } \\
\text { - Internet }\end{array}$ & $\begin{array}{l}\cdot \text { ppt } \\
\cdot \text { hot pot. } \\
\cdot \text { Sims } \\
\cdot \text { Internet } \\
\cdot \text { DTP }\end{array}$ & $\begin{array}{l}\cdot \text { ppt } \\
\cdot \text { video } \\
\cdot \text { pdf } \\
\cdot \text { hot pot } \\
\cdot \text { Sims }\end{array}$ & $\begin{array}{l}\cdot \text { - Internet } \\
\text { - Word } \\
\text { - Paint } \\
\cdot \text { ppt } \\
\text { - Inspir. } \\
\text { - photoed }\end{array}$ & $\begin{array}{l}\cdot \text { ppt } \\
\cdot \text { Excel } \\
\text { - Web Q. } \\
\text { - Internet } \\
\text { - pdf }\end{array}$ \\
\hline RQ2: How used & $\begin{array}{l}\cdot \text { teacher } \\
\text { demo } \\
\cdot \text { active } \\
\text { respond. } \\
\cdot \text { group } \\
\text { discuss. }\end{array}$ & $\begin{array}{l}\cdot \text { research } \\
\cdot \text { problem } \\
\text { solving }\end{array}$ & $\begin{array}{l}\cdot \text { teacher } \\
\text { demo } \\
\cdot \text { adv. org. } \\
\cdot \text { research } \\
\cdot \text { active } \\
\text { respond. }\end{array}$ & $\begin{array}{l}\text { - teacher } \\
\text { demo } \\
\text { - research } \\
\text { - adv. org. } \\
\text { - write/j } \\
\text { - problem } \\
\text { solving }\end{array}$ & $\begin{array}{l}\cdot \text { teacher } \\
\text { demo } \\
\cdot \text { student } \\
\text { pres. } \\
\text { - inquiry } \\
\text { - active } \\
\text { respond. }\end{array}$ & $\begin{array}{l}\text { - teacher } \\
\text { demo } \\
\text { - active } \\
\text { respond. } \\
\text { · problem } \\
\text { solving } \\
\text { - student } \\
\text { present. }\end{array}$ & $\begin{array}{l}\cdot \text { teacher } \\
\text { demo } \\
\text { - research } \\
\text { - hands-on } \\
\cdot \text { active } \\
\text { respond } \\
\cdot \text { adv. org. }\end{array}$ & $\begin{array}{l}\text { · adv. org. } \\
\text { · group } \\
\text { discuss } \\
\text { - research } \\
\cdot \text { student } \\
\text { present. } \\
\text { - hands-on } \\
\text { - inquiry }\end{array}$ & $\begin{array}{c}\text { - teacher } \\
\text { demo } \\
\text { · active } \\
\text { respond. } \\
\text { · research } \\
\text { - inquiry } \\
\text { · active } \\
\text { respond. } \\
\text { · problem } \\
\text { solving } \\
\text { - student } \\
\text { present. }\end{array}$ \\
\hline RQ3: Engagement & $\begin{array}{l}\text { - passive/ } \\
\text { interactive }\end{array}$ & $\begin{array}{l}\text { - passive/ } \\
\text { interactive }\end{array}$ & $\begin{array}{l}\text { - passive/ } \\
\text { interactive }\end{array}$ & $\begin{array}{l}\text { - passive/ } \\
\text { interactive }\end{array}$ & $\begin{array}{l}\text { - passive/ } \\
\text { interactive }\end{array}$ & $\begin{array}{l}\text { - passive/ } \\
\text { interactive }\end{array}$ & $\begin{array}{l}\text { - passive/ } \\
\text { interactive }\end{array}$ & $\begin{array}{l}\text { - passive/ } \\
\text { interactive }\end{array}$ & $\begin{array}{l}\text { - passive/ } \\
\text { interactive }\end{array}$ \\
\hline $\begin{array}{r}\text { RQ4: Learning. } \\
\text { (Use or refer to Bloom } \\
\text { or Tomei?) }\end{array}$ & $\begin{array}{l}\text { "I don’t } \\
\text { think so. I } \\
\text { do my } \\
\text { own } \\
\text { thing.” }\end{array}$ & $\begin{array}{l}\text { "...some } \\
\text { of the } \\
\text { levels." }\end{array}$ & $\begin{array}{l}\text { "No, I } \\
\text { really } \\
\text { don't go } \\
\text { through } \\
\text { that } \\
\text { reasoning. } \\
\text { " }\end{array}$ & $\begin{array}{l}\text { "I'm sure I } \\
\text { did." }\end{array}$ & "some..." & $\begin{array}{l}\text { "No, I } \\
\text { don’t } \\
\text { think I } \\
\text { used that.” }\end{array}$ & $\begin{array}{l}\text { “...makes } \\
\text { you stop } \\
\text { and think. } \\
\text { Before } \\
\text { you just } \\
\text { did it the } \\
\text { same } \\
\text { way.” }\end{array}$ & “No." & $\begin{array}{l}\text { "Not in } \\
\text { my } \\
\text { plans...but } \\
\text { will use } \\
\text { for ... } \\
\text { other } \\
\text { lessons." }\end{array}$ \\
\hline $\begin{array}{r}\text { RQ5: Cor. between } \\
\text { types and use? } \\
\text { (Success story?) }\end{array}$ & $\begin{array}{l}\text { "It } \\
\text { provides } \\
\text { extra } \\
\text { practice." }\end{array}$ & $\begin{array}{l}\text { "Not } \\
\text { geared } \\
\text { toward } \\
\text { students." }\end{array}$ & $\begin{array}{l}\text { "web } \\
\text { searchers } \\
\text {...new } \\
\text { world." }\end{array}$ & $\begin{array}{l}\text { “...like } \\
\text { problem } \\
\text { solving } \\
\text { software.” }\end{array}$ & $\begin{array}{l}\text { “...used } \\
\text { for pre- } \\
\text { teaching.” }\end{array}$ & $\begin{array}{l}\text { "enjoyed } \\
\text { inter- } \\
\text { activity" }\end{array}$ & $\begin{array}{l}\text { "video } \\
\text { transferred } \\
\text { info } \\
\text { better." }\end{array}$ & $\begin{array}{l}\text { "research } \\
\text { before- } \\
\text { hand." }\end{array}$ & $\begin{array}{l}\text { Discovery } \\
\text { learning. }\end{array}$ \\
\hline
\end{tabular}

Comments that participants made about PowerPoint demonstrated how they integrated it. Cara and Alice, both Year 1 participants, used PowerPoint for teacher demonstrations. Cara commented, “They (students) do pay attention when it is a PowerPoint. You've got colors... it’s very visual.” Alice commented that she used electronic presentations to "demonstrate a concept". She added that, "it provides extra 
practice, one-on-one with the child. Maybe I can do something else and they can do that. I don't use them as a complete teaching tool. I usually use it as a back (pauses), as an addition (pauses), and maybe a supplement at times.” When asked about how she integrated other instructional media, Alice said, "I think I just got tied up in the PowerPoint. I was having so much fun with it (laughs lightly). I enjoyed it so much (pauses) that I knew how to do it. I think that's probably why I stuck with it.” A closer examination of Alice’s web-based unit revealed that she had 11 PowerPoint presentation and 8 PowerPoint games and supplemental PowerPoints. These presentations had between 42-50 slides each (about 368 slides in all) and they were all interactive information quizzes.

On the other hand, Izzy, a high school teacher from Year 3,. used PowerPoint for teacher demonstrations and also had her students use it. "They like making their PowerPoints, but they like the format and the design part of it... of anything.” Other teachers were student-centered when they integrated other instructional media. Five of the participants listed the Internet as one of their instructional media, and six listed word processing (three referred to Word, and three referred to Portable Document Files). Other instructional media varied in type and did not seem to have an immediate pattern. Research Question 2: In what ways are the instructional media used?

Seven of the participants responded, and listed first, that they use instructional media for teacher demonstration. Six participants responded that they used instructional media for research, but only Bob, listed it first. Research may not have been integrated as effectively, or frequently, as teacher demonstrations. Assignments that involve the use of 
the Internet may have other barriers. Hana commented that, “They love the Internet, but they were constrained in that they had certain sites that they could go to and that was it.” Research Question 3: What is the level of student engagement with the instructional media?

All of the teachers interviewed remarked that their lessons had both passive and interactive elements. Two commented that their unit was not student-centered as much as it could have been (Table 24), and Bob, a first year participant commented that

It's not as geared toward the students as I would have (liked to have) made it. It's more like all of my teaching supplies that I use to teach. It's handy for me to go in there and get them. It's all organized for me the teacher. There's very little in there where I can say, "OK, kids, log on here and then interact with the technology."

Alice said that, “they (kids) have to be busy, especially this day and age.” This belief was reflected in her web unit (19 PowerPoint presentations, all of which are interactive) and supports her preference for interactive PowerPoints for her students.

Research Question 4: What level of learning did the instructional media address?

Participants were either unsure as to how to answer or not clear about this question’s meaning. An alternate question was, “Did you use or refer to Bloom’s or Tomei’s taxonomy?” Four participants said that they did not; two participants said that they referred to the taxonomies some, and two said, yes. Gina said that the taxonomies, “...make you stop and think, before you just did it the same way. I just didn’t think that technology was even a possibility. You start out with a basic level and work your way up. Oh, yeah, it can be done.” Although they did not address a specific level, some 
remembered hearing it discussed during the Institute. Bob said, "Having them in front of you when creating your lesson will give you something to shoot for...some of the levels.” Research Question 5: Is there a correlation between types and use of instructional media and cognitive levels of learning?

Participants were either unsure as to how to answer or not clear about this question's meaning. An alternate question was asked that was meant to illicit a response about an instructional media that the participant thought was successful at a higher level of learning; "What component do you think transferred the information to the children better?

Cara and Edd referred to web searches as the most successful component in their units. Cara said that, "web searches open up a whole new world.” Edd had the students use the Web for research before a lesson for "pre-teaching, it really helped them get ready... and I think they appreciate it a little bit more.”

Emergent Themes. Some of the most revealing comments concerning the types and uses of instructional media and the cognitive levels of learning were revealed during the interview, but not as a direct response to an interview question. Key words and phrases not directly related to the research questions were noted with a frequency count and key words with the most responses were entered into a two-dimensional table.

Time emerged as one of the themes and was related to used parts of the unit, another theme. Table 24 shows that all of the participants expressed concern about time. The web unit both took time to implement and saved time when implemented. Alice commented that she would like to make some changes and adjustments to her unit, but “you know, I really would like to, but I don’t have time.” 
Two of the participants viewed web-based lessons as time savers. Edd commented that, "Having the information ahead of time... kids could go at their own pace. They could go back and look at the things again and again if it was something that really interested them. They interact with the lesson instead of me presenting the lesson. (My) presentation in class was a one time shot.” Gina expressed both frustration and satisfaction with her web unit.

As far as the technology part? I haven't gotten the whole class doing all of the technology at one time yet. I use them in smaller groups right now. It's just [pauses] the Internet stuff, the wiring in the school is so slow. I spend more of my time trying to get the kids on the site than actually getting to use it. I think one day I was trying (and) it took me 45 minutes to get the kids on the site. By the time I got them on, it was time to send them back to class. I haven’t used it as often as I'd like to.

As frustrating as her comment sounds, she has used her unit 15 to 20 times compared to others who average around 4 uses. She later said, "Well, it's a time saver for me. I mean I don't have to [pauses], it allows the (students to) go over certain parts. They can watch the video clip, then go back, and do it where before I had to go and take them and go through it. It's a big time saver for the kids to go over. It's more independent for the kid, which is what we were supposed to do.”

Her comments help to explain Used Part of the Unit, another theme, which was brought up by all participants. Alice offered a couple of reasons for not using the entire web-based unit. “I just used it one time. I didn’t use it this year because most of my kids already knew it (unit content). It wasn’t appropriate to use it. I might have used it for one 
child, but I didn’t use it class wise.” Later she commented that she used part of her unit because, "I just use the ones (lessons) that I need and basically what I need mostly (are) the games [laughs].” Dora said she used her unit twice because,

I had so much more in there than I was able to do. I picked bits and pieces of it. (I) just couldn’t do everything I wanted to do in the amount of time I had [laughs]. I would do more of that if I had the time. It takes a lot of time. Once you get it done though it's great. It just takes a lot of time to sit down and think through all those things. Especially if you have [pauses] you know? You click on this and something else happens, and all that, and trying to get the good images on there. It's really time consuming.

This same teacher expressed frustration with the integration of her unit, "Unfortunately, it (the Internet) seems to me $60 \%$ of the time the site (external link in her unit) is down. You get the kid on and you try to get started and it won't load up. That's frustrating.”

These themes (not enough time, used parts of the unit, lab time a concern, and unit is supplemental) illustrate that although the unit was prepared with specific instructional media in mind, the unit may not have been used as it was intended and only bits and pieces, (another theme) were used. Internet access and information retrieval were the primary IM, according to lesson sweeps (Table 7) that were integrated into web-based units. However, additional data garnered from the interviews suggest that some teachers were frustrated with Internet access and used selected IM from their lessons.

Three other emergent themes are interrelated. Some participants noted that the instructional media was not appropriate, equipment was limited or wasn't the right 
equipment, and the participant either could not do or was uncomfortable with the instructional media. Alice commented, “I just used it (web unit) one time. I didn’t use it this year... because it wasn't appropriate to use it. I might have used it for one child but I didn't use it class wise. Alice explained later that her web unit contained content that her new students already knew.

Bob said that there were instructional media that he would have liked to have included but, “some that I tried didn’t work because of the system we had at school. I was trying to do some data collection—student interest and feedback from the trip. They would do online and I would collect data, but it just didn’t work.” Cara explained that the reason she did not use specific instructional media was that, "Maybe there were some things that I didn’t know how to use very well and would have been very time consuming for me to learn. It probably was a matter of dedicating that much time for that, that I decided that I can’t do that. I feel fairly proficient at PowerPoint so that was easier for me.”

Themes that emerged showed us how the teachers felt about integrating instructional media, and how they teach with their unit. Data from emergent themes illustrate that time, equipment, appropriate content (when web unit is repeated with another class), and comfort with IM influence the types and use of instructional media. Participants have answered why to the research questions that asked, what, thus adding depth to the study.

Table 28 shows the comparison of quantitative and qualitative findings associated with each research question. Table 26 shows that quantitative results for RQ 1 to RQ 3 are closely correlated with qualitative results for RQ 1 to RQ 3. Although results are not 
identical for RQ 1, word processing was mentioned by the intensity sampling, two of the three IM correlate. Engagement answers were identical although the results from the intensity sample were not quantified. RQ 4 was perhaps not explored deeply enough with the intensity sample. Quantitative results based on frequency of use indicated that most of the IM were integrated into web unit at low levels. There were incidences of IM being integrated at higher levels, but not frequently. The results of the quantitative analysis for RQ 5 revealed participants in this study most frequently integrated specific IM at specific levels on each taxonomy. The results of the qualitative analysis for RQ 5 revealed specific media were mentioned by participants that they thought transferred the information to the children better and each participant commented on an IM that they felt successfully transferred information to the student. They identified an IM that successfully aligned with a specific objective.

Table 28

Summary of Quantitative and Qualitative Data Analysis

\begin{tabular}{|c|c|c|}
\hline Research Question & Quantitative & Qualitative \\
\hline RQ1: Types of IM & $\begin{array}{l}\text {-Internet Access } \\
\text { •Information Retrieval } \\
\text { •Electronic Pres. }\end{array}$ & $\begin{array}{l}\text { - Electronic Pres. } \\
\text { - Internet Access } \\
\text { •Word Processing }\end{array}$ \\
\hline RQ2: Ways Used & $\begin{array}{l}\text {-Inquiry } \\
\text { - Teacher Demonstrations } \\
\text { • Research }\end{array}$ & $\begin{array}{l}\text { - Teacher Demonstration } \\
\text { • Research }\end{array}$ \\
\hline RQ3: Engagement & - $86 \%$ Active , $14 \%$ Non-Active & • “Active \& Passive” \\
\hline RQ4: Level of Learning & - Mode = Low $(1-2)$ & •*Some levels. Not specific. \\
\hline RQ5: Correlation: Types \& Use & $\begin{array}{l}\text { - Some correlation with specific } \\
\text { IM }\end{array}$ & $\begin{array}{l}\text { *Web searches, most } \\
\text { effective. }\end{array}$ \\
\hline
\end{tabular}

\footnotetext{
*Alternate questions.
} 


\section{CHAPTER V}

\section{Discussion, Conclusion, Recommendations}

This chapter includes a discussion of the findings and conclusions made in relation to the five research questions that guided the study. The purpose of the study was to illustrate the potential for improved learning through the used of interactive instructional media. Types of instructional media used in P-12 web-based learning were identified along with the ways in which the instructional media were used. Data shows that when instructional media were present in a lesson the students were actively engaged. Results indicated that the instructional media that participants integrated were most frequently used at the lower levels on Bloom's and Tomei’s taxonomies, while other instructional media, although less frequently integrated, were integrated at higher levels on the two taxonomies.

Research Question 1: What types of instructional media do P-12 teachers integrate into web-based learning?

Analysis of the types of instructional media that teachers integrate into web-based learning revealed that Internet access and information retrieval were the two most frequently integrated. This is not surprising considering the delivery method. Combined, these two instructional media accounted for over half of all instructional media that were integrated, which illustrates that the participants were addressing the relevance of webbased instruction and truly integrating the use of the Internet.

Electronic presentations were the third most frequently integrated instructional media. The high frequency of use may be attributed to various ways that the IM were integrated. Subsequent research showed (RQ2) ways IM could be used by the student and 
by the teacher. Additional information obtained from in-depth interviews indicated that many of the participants felt more comfortable using this IM and also felt comfortable allowing students to use it. One participant commented that, "Every time you do a technology, anything you learn you get more comfortable with.” Another participant said, "I think I just got tied up in the PowerPoint. I was having so much fun with it (laughs). I enjoyed it so much, that I knew how to do it.”

Based on these findings, the types of instructional media that teachers integrate into web-based learning are primarily the ones that are dependent on the mode of delivery. Teachers also integrated instructional media that they had experienced and felt comfortable integrating. “I would not use something that I didn’t feel confident that I knew. And the thing is that sometimes the kids know (how to use) it (laughs). I had to know it.”

Quantitative data showed that the types of instructional media that teachers integrated into web-based learning were Internet access and information retrieval. In addition to these web specific instructional media, teachers also integrated electronic presentations. These three media combined represented about two-thirds of all instructional media integrated by the participants. Qualitative data corroborates these results and further revealed that while the participants used instructional media appropriate for the delivery medium (web-based), they integrated instructional media with which they had the most experience and were most comfortable using. Research Question 2: In what ways are the instructional media used?

Specific instructional media (IM) were linked to instructional strategies (IS) to define the ways in which instructional media were used. Participants who were 
considered high usage teachers were identified by selecting the median of the number of active instructional media integrated into a lesson. Data revealed that the range of IM that were integrated per lesson was from a low of 1 to a high of 6 . The median, 3.5 was rounded down to provide a strong sampling of 36 participants who integrated three or more instructional media per lesson plan.

Lesson sweep data revealed that the most concentrated use of a specific IS associated with a specific IM was inquiry, which was associated with the most frequently used instructional media, Internet access. Other instructional strategies that seemed to be clustered around specific media included teacher demonstration with electronic presentations and advanced organizers with word processing. The teachers used electronic presentations exclusively for their demonstrations and word processing for advanced organizers such as handouts and review sheets.

The most frequently used instructional strategy associated with a specific instructional media was active responding. Its use involved multiple instructional media: Internet access, information retrieval, word processing, simulations/educational games, email, electronic presentations, and open lab. However, seven of the identified twelve instructional media were active responding. When an instructional strategy was clustered around a specific media, the instructional media was primarily associated with that strategy. A pattern emerged that indicated that Internet access and information retrieval, the most frequently integrated IM, were used primarily for inquiry and research, but were also used for active responding. Therefore, these web-specific instructional media were most frequently used for research (inquiry), but were also used for online quizzes, simulations, and educational games (active responding). In addition, the patterns of the 
ways in which IM were most frequently integrated revealed electronic presentations were most frequently used for teacher demonstrations. Interview data confirmed that the participants integrated web-based instructional media first. The data revealed that the teachers next integrated instructional media with which they felt most comfortable and with which they had the most experience.

Research Question 3: What is the level of student engagement with the instructional media?

Having examples of active and non-active IM will help teachers when they design lessons for the web. Student engagement with the instructional media was either an active or a non-active level. Of the lessons swept that indicated instructional media present, 86\% included the use of instructional media at an active level. The majority of web-based lessons where active instructional media were present actively engaged the student. Interactivity occurs when the student is engaged in an active and reflective way with the media, that is, the student makes a choice after being presented with a problem (Misovich, et al., 2003). When a learner interacts with the content, active learning takes place and has the potential to raise a learner's cognitive level (Fetherston, 2001).

Since the participants web units demonstrated that $86 \%$ of the instructional media integrated actively engaged students, the probability exists that the instructional media were addressing higher order thinking of learners. Because Bloom’s (1956) taxonomy of educational objectives and Tomei's (2001) taxonomy of instructional technology were demonstrated, discussed, and implemented during Trek 21, the use of these taxonomies contributed to the successful integration (86\%) of active instructional media. Data from interviews corroborated these findings in that four of the nine participants (Table 27) 
indicated that they used or referred to the taxonomies while designing their units and one said that she referred to the taxonomies when she designed other, non web-based lessons. Research Question 4: What level of learning did the instructional media address?

To address the level of learning that the instructional media address, nine participants were selected through purposeful sampling and a comprehensive sweep was conducted on five lessons in each of their web-based units. The way in which the instructional media were used, that is, the instructional strategy that was directly associated with the IM, determined the level of learning the media addressed. Instructional strategies identified by previous lesson sweeps guided the selection of instructional strategies during the comprehensive sweep. For consistency when identifying specific instructional strategies, descriptors and examples of instructional strategies found in swept lessons were added to Bloom’s (1956) taxonomy. The purpose of the comprehensive lesson sweep was to identify instructional media and determine the ways in which the instructional media were used. During the process of reviewing each lesson, every IM was given a numerical value based on the linked instructional strategy and associated level on Bloom’s taxonomy.

Findings indicated that word processing, information retrieval, Internet access electronic presentations, and open lab were most frequently integrated at Level 1, Knowledge. CAI/drill and practice, and email were most frequently integrated at Level 2, Comprehension. Although desktop publishing received a numerical value of 5 , which on Bloom's taxonomy is Evaluation, this IM was only integrated three times. Bloom's (1956) taxonomy was designed as a framework for educational outcomes. The taxonomy categorizes levels of learning in a hierarchy of progressively more complex stages. 
Teachers would have a framework for addressing higher levels according to Bloom (1956) if they know the association of instructional media with instructional strategies.

The limitation of the above example is that there were many examples of the ways in which information retrieval, Internet access, video, electronic presentations, and word processing, were used in these web-based lessons. There were only two examples of desktop publishing. While literature reviewed indicated that creating with multimedia required a higher level of thinking than using multimedia (Mitchell, 2003), more examples of the ways in which desktop publishing was integrated would yield a stronger guide for its integration. However, the potential for improved learning through the use of interactive multimedia is illustrated by instructional media such as desktop publishing and authoring/multimedia development which, when integrated, were associated with higher cognitive levels of learning on Bloom's (1956) taxonomy.

Research Question 5: Is there a correlation between types and use of instructional media and cognitive levels of learning?

To examine the correlation between types and use of instructional media and levels of learning, each instructional media was assigned a numerical value using Tomei’s (2001) instructional technology taxonomy. Tomei's instructional technology taxonomy uses the same framework as Bloom's (1956). The similarities of the two taxonomies are discussed in the literature review section of this study. A correlation between the types and use of instructional media and cognitive levels of learning was expected because of the strong similarities of Bloom's and Tomei's taxonomies. Findings in this study indicated that seven of the twelve types of instructional media (simulations, word processing, email, authoring/multimedia, electronic presentations, video, and open 
lab access) were most frequently integrated at equal levels on both Bloom's and Tomei's taxonomies. The results of this study therefore support the literature findings.

The research questions in this study were designed to systematically address types and use of instructional media associated with levels of cognitive learning. The results of this study identified types of instructional media used by P-12 teachers for Web-based environment by first examining completed web units by Trek 21 participants to identify ways in which the instructional media were integrated and at what level revealed specific instructional media were associated with specific levels of cognitive learning. Therefore, this study finds that there is a potential for improved learning through the use of active instructional media and that specific instructional technologies are more apt to promoter higher order thinking than others. Summary of Conclusions

The types of instructional media that P-12 teachers most frequently integrated into web-based learning were the ones that were web dependent, Internet access and information retrieval. They also integrated the instructional media that they were experienced in using and instructional media with which they felt most comfortable, electronic presentations. Instructional media were linked to instructional strategies to define the ways in which instructional media were used. Data revealed that Internet access and information retrieval were the most frequently integrated instructional media and these were used primarily for inquiry and research, but were also used for active responding. Interview data corroborated these findings and revealed that teachers next integrated instructional media they felt comfortable using and had experience using. 
The web-based units where active instructional media were present actively engaged the student, which indicated that active instructional media has the potential to address higher order learning. Data from interviews indicated that Trek 21 participants referred to and integrated strategies associated with Bloom's (1956) and Tomei's (2001) taxonomies, therefore, these web-based units have the potential to address higher levels of learning. Instructional media that ranked high on both Bloom's and Tomei's taxonomies were most frequently student-centered, desktop publishing and authoring/multimedia. However, findings indicated that most of the instructional media were most frequently integrated at low levels (Levels 1 and 2). This may be attributed the skill or comfort level of teachers, in that teachers integrate instructional media with which they have experience and are comfortable using.

The conclusion is that there is a correlation between the types and uses of instructional media and the cognitive levels of learning. Instructional media that teachers integrated were at equal levels on both Bloom's (1956) and Tomei’s (2001) taxonomies. Furthermore, although most of the instructional media were most frequently integrated at low levels according to each taxonomy, the potential exists that active instructional media have the potential to engage students in higher order thinking.

\section{Recommendations}

Instructional opportunities should be provided for teachers that demonstrate various types and uses of instructional media. The instructional media should include common IM and high-end instructional media (with an appropriate amount of time in which to learn and to apply new skills and knowledge) so that the teachers are more aware of what is available and how IM may be used. The study and practice of both 
Bloom's (1956) and Tomei’s (2001) taxonomies should be included in pre-service teacher technology strands. Teachers also need release time to attend instructional opportunities and to design lesson plans that integrate IM. Teachers will use instructional media that is available. Successful integration of instructional media will depend on hardware and software, and support issues including time, technical support, and training. Because of continually changing technologies, sustaining technology integration will only be effective and long-term if issues associated with using and integrating technologies are addressed.

The purpose of this study was to analyze multiple media as instructional technologies used to enhance interactivity in a web-based environment and to illustrate the potential for improved learning with interactive multimedia. This study identified instructional media that teachers use, the level of engagement with the media, and determined that there was a correlation between the types and use of instructional media and cognitive level of learning. Participants in this study commented that they used what they had available, and that generally they were not supplied by their school with funds to purchase additional software. Assessments should investigate training specific to needs of the teachers for hardware and software, and options for meeting these needs.

Based on emergent themes from interview data, time was a major concern and should be explored from all perspectives with students, teachers, administrators, and school systems in mind. Schools should include the implementation of professional development that would explain and demonstrate the customized taxonomies to P-12 teachers. An evaluation could focus on whether an understanding of the customized taxonomies assisted teachers in planning for higher levels of student achievement. 


\section{Further Research}

A key fact discovered by the interviews was that all of the participants selected for the intensity sample used parts of their units. Many talked about using parts of their web-based unit and how the parts they selected were integrated into the classroom. Examining these specific parts and uses of instructional media that teachers selected to use should be very illuminating. Did the teachers select interactive media, teacher demonstrations, or handouts? Knowing what they selected and why will indicate what the teachers feel to be the best parts of instructional media. Case studies that include the examinations of the bits and pieces that teachers selected and why they chose them should reveal which instructional media teachers believe to be of most benefit to instruction. Further research should include additional information about the utilization of Tomei’s (2001) taxonomy of instructional media, who is using Tomei’s taxonomy and why. Finally, future research should examine which instructional media are so commonly used that they are transparent (fully integrated and not considered to be a technology) and what path the instructional media took in order to be transparent. 


\section{Bibliography}

Adams, L., Dunham, T., Wells, J., \& Shambaugh, N. (2001). Trek 21: A PT3 project to facilitate teachers' design of engaging learning environments. Retrieved May 29, 2003 from http://trek-21.wvu.edu/html/disfiles/sitte2001/WVU-Trek21SITE2001.pdf

Alessi, S. M., \& Trollip, S. R. (2001). Multimedia for learning: Methods and development ( $3^{\text {rd }}$ ed.). Boston: Allyn and Bacon.

Almond, P., Tindal, G., \& Stieber, S. (1997). Linking inclusion to conclusions: An empirical study of participation of students with disabilities in statewide testing programs (Oregon Report 1). Minneapolis, MN: University of Minnesota, National Center on Educational Outcomes. Retrieved November 20, 2003, from http://education.umn.edu/NCEO/OnlinePubs/OrReport1.html

Anderson, L. W., Krathwohl, D. R., Airasian, P. W., Cruikshank, K. A., Mayer, R. E., Pintrich, P. R., Raths, J., \& Wittrock, M. C. (Eds.). (2001). A taxonomy for learning, teaching, and assessing: A revision of Bloom's taxonomy of educational objectives.(Abridged Edition). New York: Addison Wesley.

Anderson, T. (2002). An updated and theoretical rationale for interaction. Retrieved March 25, 2003, from http://it.coe.uga/itforum/paper63/paper63.htm

Baker, R. K. (2003). A framework for design and evaluation of Internet-Based distance learning courses phase one - framework justification, design and evaluation. Online Journal of Distance Learning Administration, 6(1). Retrieved November 11, 2003, www.westga.edu/ distance/onjdla/summer62/baker62.html 
Bates, A. W. (1994). Educational multi-media in a networked society. Retrieved March 27, 2000, from http://bates.cstudies.ubc.ca/edmedia.html

Bagui, S. (1998). Reasons for increased learning using multimedia. Journal of Educational Multimedia and Hypermedia, 7(1), 3-18.

Bitter, G, \& Pierson, M. (2002). Using technology in the classroom (5 ${ }^{\text {th }}$ ed.). Boston: Allyn and Bacon.

Bloom, B. S. (Ed.). (1956), Englehart, M. D., Furst, E. J., Hill W. H., \& Krathwohl, D. R. (1967). Taxonomy of educational objectives: The classification of educational goals, handbook 1, cognitive domain. New York: David McKay Company. Bottrill, P. (1995). Designing and learning in the elementary school. International Technology Education Association, Reston, VA. (ERIC Document Reproduction Services No. ED381387)

Bruce, B. C., \& Levin, J. A. (1997). Educational technology: Media for inquiry, communication, construction, and expression, Journal of Educational Computing Research, 17(1), 79-102. Retrieved May 18, 2002 from http://alexia.lis.uiuc.edu/ chip/pib/taxonomy/

Brunner, C., \& Tally, W. (1999). The new media literacy handbook: An educator's guide to bringing new media into the classroom. New York: Doubleday.

Bullock, C., \& Ory, J. (2000). Evaluating instructional technology implementation in a higher education environment. American Journal of Evaluation, 21(3), 315-329.

Chen, T. L., \& Chen, T. J. (2002). A strategic analysis of the online learning community for continuing professional development of university faculty in Taiwan: A SWOT analysis. Proceedings of the International Conference on Computers in 
Education (ICCE '02). Retrieved November 19, 2003, from http://info.computer.org/proceedings/icee/1509/15091408.pdf

Clark, R. C., \& Mayer, R. E. (2003). e-learning and the science of instruction: Proven guidelines of multimedia learning. San Francisco, CA: Jossey-Bass/Pfeiffer.

Collis, B., \& Moonen, J. (2001). Flexible learning in a digital world: Experiences and expectations. London: Kogen Page Limited.

Counts, E. L. (2004). Multimedia design and production for students and teachers. Boston: Pearson.

Creswell, J. W. (2003). Research design: Qualitative, quantitative, and mixed methods approaches $\left(2^{\text {nd }}\right.$ ed.). Thousand Oaks, CA: Sage Publications.

Creswell, J. W., \& Miller, D. L. (2000, Summer). Determining validity in qualitative inquiry. Theory Into Practice, 39(3), 124-129. Retrieved August 23, 2003 from http://eris.knue.ac.kr/e-tip/f-tip-00-39-2/lkf01920.pdf

Cunningham, C. A., \& Billingsley, M. (2003). Curriculum webs: A practical guide to weaving the web into teaching and learning. Boston, MA: Pearson Education.

Dewey, J. (1943). The child and the curriculum/The school and society. Chicago: University of Chicago Press.

Dempsey, J. V., \& Eck, R. V. (2002). Instructional design online: Evolving expectations. In Robert A. Reiser, \& John V. Dempsey (Eds.), Trends and issues in instructional design and technology, 281-294. Upper Saddle River, NJ: Merrill Prentice Hall. 
Design-Based Research Collective. (2002). Design-Based Research: An emerging paradigm for educational inquiry. University Park, PA. Retrieved November 19, 2003, from www.aera.net/pubs/er/pdf/vol32_01/AERA320104.pdf

Dick, W., Carey, L., \& Carey, J. O. (2001). The systematic design of instruction (5 ${ }^{\text {th }}$ ed.). New York: Longman.

Dixon-Kraus, L. (1996). Vygotsky in the classroom: Mediated literacy instruction and assessment. White Plains, NY: Longman.

Driscoll, M. (1998). Web-Based training: Using technology to design adult learning experiences. San Francisco: Jossey-Bass Pfeiffer.

Elin, L. (2001). Designing and developing multimedia: A practical guide for the producer, director, and writer. Boston: Allyn and Bacon.

Ertmer, P. A., Gopalakrishnan, S., \& Ross, E. M. (2001). Technology-Using teachers: Comparing perceptions of exemplary technology use to best practices. Journal of Research on Technology in Education, 33(5). Retrieved November 9, 2001, from www.iste.org/jrte/33/5/ertmer.html

Ertmer, P. A., \& Quinn, J. (1999). The ID casebook: Case studies in instructional design. Upper Saddle River, NJ: Prentice-Hall.

Fetherston, T. (2001). Pedagogical challenges for the World Wide Web. Educational Technology Review: International Forum on Educational Technology Issues and Applications, Issue 1, 2001. Retrieved November 9, 2001, from www.aace.org/pubs/etr/fetherston.cfm

Forcier, R. C., \& Descy, D. E. (2002). The computer as an educational tool: productivity and problem solving ( $3^{\text {rd }}$ ed.). Upper Saddle River, NJ: Merrill Prentice Hall. 
Glass, G. V., \& Hopkins, K. D. (1996). Statistical methods in education and psychology ( $3^{\text {rd }}$ edition). Boston: Allyn and Bacon.

Harris, J. (1998a). Virtual architecture: Designing and directing curriculum-based telecomputing. Eugene, OR: International Society for Technology in Education.

Harris, J. (1998b). Design tools for the Internet-supported classroom. Upper Saddle River, NJ: Prentice Hall.

Hawthorne, R., Walls, R., \& Wells, J. G. (1999). Trek 21 Rubric. Unpublished scoring rubric, West Virginia University.

Heinich, R., Molenda, M., Russell, J. D., \& Smaldino, S. E. (2002). Instructional media and technologies for learning ( $7^{\text {th }}$ ed.). Upper Saddle River, NJ: Merrill Prentice Hall.

Heller, S., \& Drennan, D. (1997). The digital designer: The graphic artist's guide to the new media. New York: Watson-Guptill Publications.

Hopkins, W. G. (2000). Quantitative research design. Sportscience, 4(1). Retrieved November 11, 2003 from http://sportsci.org/jour/0001/wghdesign.html Hooper, S., \& Reinartz, T. J. (2002). Educational multimedia. In Robert A. Reiser, \& John V. Dempsey (Eds.), Trends and issues in instructional design and technology, 307-318. Upper Saddle River, NJ: Merrill Prentice Hall.

Horton, W. (2001). Evaluating e-learning. Alexandria, VA: American Society for Training \& Development.

Jonassen, D. H. (2000). Computers as mindtools for schools: engaging critical thinking ( $2^{\text {nd }}$ ed.). Upper Saddle River, NJ: Merrill. 
Jonassen, D. H., Peck, K. L., \& Wilson, B. G. (1999). Learning with technology: A constructivist perspective. Upper Saddle River, NJ: Prentice-Hall.

Jonassen, D. H., Howland, J., Moore, J., Marra , R. M. (2003). Learning to solve problems with technology: A constructivist perspective ( $2^{\text {nd }}$ ed.). Upper Saddle River, NJ: Merrill Prentice Hall.

Jones, M. G., Harmon, S. W., \& Lowther, D. (2002). Integrating web-based learning in an educational system: A framework for implementation. In Robert A. Reiser, \& John V. Dempsey (Eds.), Trends and issues in instructional design and technology, 295-306. Upper Saddle River, NJ: Merrill Prentice Hall.

Kemp, J. E., Morrison, G. R., \& Ross, S. M. (1998). Designing effective instruction ( $2^{\text {nd }}$ ed.). Upper Saddle River, NJ: Prentice Hall.

Keirns, J. L. (1999). Designs for self-instruction: Principles, processes, and issues in developing self-directed learning. Boston: Allyn and Bacon.

Kearsley, G., \& Shneiderman, B. (1999). Engagement theory: A framework for technology-based teaching and learning. Retrieved August 30, 2000, from http://home.sprynet.com/ gkearsley/engage.htm

Krathwohl, D. R., Bloom, B. S., Masia, B. B. (1967). Taxonomy of educational objectives: The classification of educational goals, handbook II: affective domain ( $4^{\text {th }}$ printing). New York: David McKay Company.

Kristof, R., \& Satran, A. (1995). Interactivity by design: Creating \& communicating with new media. Mountain View, CA: Adobe Press. 
Kuhn, A. L., Lemani, C. N., Wells, D. L., Mitchem, K. J., Wells, J. G. (2003). Integration of instructional technologies and change in teacher practice. Retrieved August 27, 2003, from http://www.trek-21.wvu.edu/html/research/dissefforts.htm

Kurubacak, G., \& Baptiste, H. P. (2003). Creating a virtual community with PT3: College of education students' beliefs, expectations and attitudes toward online learning. Retrieved October 30, 2003, from www.distanceeducator.com/dnews/article10066.phtml

Laurillard, D. (2002). Rethinking university teaching: A conversational framework for the effective use of learning technologies ( $2^{\text {nd }}$ ed.). New York: Routledge/Falmer.

Laurillard, D., \& Taylor, J. (1994). Designing the stepping stones: An evaluation of interactive media in the classroom. Journal of Educational Television, 20(3). Retrieved November 7, 2003, from http://web25epnet.com

Lee, W. W., \& Owens, D. L. (2000). Multimedia-Based instructional design: Computerbased training, web-based training, distance broadcast training. San Francisco: Jossey-Bass Pfeiffer.

Lever-Duffy, J., McDonald, J. B., \& Mizell, A.P. (2003). Teaching and learning with technology. Boston: Ablongman.

Liao, Y. C. (1999). Effects of hypermedia on students’ achievement: A meta-analysis. Journal of Educational Multimedia and Hypermedia, 8(3), 255-277.

Logan, C., Fox, M. K., \& Lin, B. H. (n. d.). Effects of food assistance and nutrition programs on nutrition and health: Volume II, data sources. Retrieved November 19, 2003, from www.ers.usda.gov/publications/FANRR19-2a.pdf 
Lynch, P. J., \& Horton, S. (1999). Web style guide: Basic design principles for creating web sites. New Haven, CT: Yale University Press.

Lynch, R. L. (1996). In search of vocational and technical teacher education. Journal of Vocational and Technical Education, 13(1). Retrieved November 13, 2003 from http://scholar.lib.vt.edu/ejournals/JVTE/v13n1/lynch.html.

Mayer, R. E. (2001). Multimedia learning. New York: Cambridge University Press.

McCombs, B. L. (2000). Assessing the role of educational technology in the teaching and learning process: A learner-centered perspective. Retrieved September 7, 2002, from www.ed.gov/Technology/techconf/2000/mccombs_paper.html

McMillan, J. H., Schumacher, S. (1997). Research in education: A conceptual introduction ( $4^{\text {th }}$ ed.). New York: Addison-Wesley Educational Publishers.

Merrill, P. F., Hammons, K., Vincent, B. R., Reynolds, P. l., Christensen, L., \& Tolman, M. N. (1996). Computers in education ( $3^{\text {rd }}$ ed.). Boston: Allyn and Bacon.

Merriam, S. B. (1988). Case study research in education: A qualitative approach. San Francisco, CA: Jossey-Bass.

Misovich, S. J., Katrichis, J., Demers, D., \& Sanders, W. B. (2003). An introduction to interactive multimedia. Boston: Pearson Education.

Mitchell, M. (2003). Constructing Multimedia: Benefits of student-generated multimedia on learning. Interactive Multimedia Electronic Journal of Computer-Enhanced Learning. Retrieved November 17, 2003 from http://imej.wfu.edu/articles/2003/1/03/printver.asp

Mitchem, K., \& Wells, D. (2002b.). Trek 21 Evaluation Report Lesson Sweep Analyses for K-12 Participants Institute Years 1-3, unpublished report. 
Mitchem, K., Wells, D., \& Wells, J. (2003). Effective integration of instructional technologies (IT): Evaluating professional development and instructional change. Journal of Technology and Teacher Education 11(3), 397-414. [Online]. Available: http://dl.aace.org/13574

Moreno, R., \& Mayer, R. E. (2000). A learner-centered approach to multimedia explanations: Deriving instructional design principles from cognitive theory. Interactive Multimedia Electronic Journal of Computer-Enhanced Learning. Retrieved November 17, 2003, from http://imej.wfu.edu/articles/2000/2/05/printver.asp

Morrison, G. R., \& Lowther, D. L. (2002). Integrating computer technology into the classroom ( $2^{\text {nd }}$ edition). Upper Saddle River, NJ: Merrill Prentice Hall

Morrison, G. R., Ross, S. M., \& Kemp, J. E. (2001). Designing effective instruction (3 ${ }^{\text {rd }}$ edition). NY: John Wiley \& Sons.

Newby, T. J., Stepich, D. A., Lehman, J. D., \& Russell, J. D. (1996). Instructional technology for teaching and learning: Designing instruction, integrating computers, and using media. Upper Saddle River, NJ: Prentice-Hall.

Norton, P., \& Wilburg, K. M. (2003). Teaching with technology: Designing opportunities to learn ( $2^{\text {nd }}$ ed.). Ontario: Wadsworth.

Oka, T., \& Shaw, I. (2000). Qualitative research in social work. Retrieved November 11, 2003, from http://pweb.sophia.ac.jp/ t-oka/qrsw.html.

Patton, M. Q. (1990). Qualitative evaluation and research methods (2 ${ }^{\text {nd }}$ ed.). Newbury Park, CA: Sage Publications. 
Patton, M. Q. (1987). How to use qualitative methods in evaluation. Newbury Park, CA: Sage Publications.

Palak, D., Jalumuri, N., Wells, J. G., Walls, R. T. (2002). Choice of instructional technologies in P-12: What and how teachers chose. Society for Information Technology \& Teacher Education International Conference, Vol. 2003, Issue 1, 2003, pp 1045-1052. Retrieved August 27, 2003 from http://rek-21.wvu.edu

Preece, J., Rogers, Y., \& Sharp, H. (2002). Interaction design: Beyond human-computer interaction. New York: John Wiley \& Sons.

Reiser, R. A. (2002). What Field did you say you were in? In Robert A. Reiser, \& John V. Dempsey (Eds.), Trends and issues in instructional design and technology, 525. Upper Saddle River, NJ: Merrill Prentice Hall.

Reiser, R. A., \& Dempsey, J. V. (Eds.). (2002). Trends and issues in instructional design and technology. Upper Saddle River, NJ: Merrill Prentice Hall.

Roblyer, M. D., \& Edwards, J. (2000). Integrating educational technology into teaching ( $2^{\text {nd }}$ ed.). Upper Saddle River, NJ: Prentice-Hall.

Rogers, P. L. (2002). Designing instruction for technology-enhanced learning. Hershey, PA: Idea Group Publishing.

Singh, K., \& Billingsley, B. S. (1996). Intent to stay in teaching. Remedial \& Special Education, 17(1). Retrieved November 13, 2003, from http://80web20.epnet.comwww.libproxy.wvu.edu

Spradley, J. P. (1979). The ethnographic interview. New York: Holt, Rinehart and Winston. 
Stoney, S., \& Oliver, R. (1999). Can higher order thinking and cognitive engagement be enhanced with multimedia? Interactive Multimedia Electronic Journal of Computer-Enhanced Learning. Retrieved November 8, 1999, from http://imej.wfu.edu/articles/1999/2/07/index.asp

Swortzel, K. (1996). In search of vocational and technical teacher education. Journal of Vocational and Technical Education, 13(1). Retrieved November 13, 2003, from http://scholar.lib.vt.edu/ejournals/JVTE/v13n1/lynch.html

Tashakkori, A., \& Teddlie, C. (Eds.). (1998). Mixed methodology: Combining qualitative and quantitative approaches. Thousand Oaks, CA: Sage Publications.

Tomei, L. A. (2002). The technology façade: Overcoming barriers to effective instructional technology. Boston: Allyn and Bacon.

Tomei, L. A. (2001). Teaching digitally: A guide for integrating technology into the classroom. Norwood, MA: Christopher-Gordon Publishers.

Tomei, L. A. (ND). Taxonomy, for the technology domain. Retrieved April 26, 2002, from http://www.duq.edu/ tomei/heinz/taxonomy/

Uden, L. (2002). Designing hypermedia instruction, in Designing instruction for technology-enhanced learning, Patricia L. Rogers, (Ed.). Hershey, PA: Idea Group Publishing.

Ungar, J. (1985). Rendering in mixed media: Techniques for concept presentation for designers and illustrators. New York: Watson-Guptill Publications.

Van Zant, A., Mitchem, T., Shambaugh, N. (2001). Teacher change in unit development: Initial steps_initial results of a PT3 grant. Retrieved March 19, 2002 from www.trek-21.wvu.edu/html/research,dissefforts.htm. 
Webb-Dempsey, J., Shambaugh, N., Wells, J., Dempsey, V. (2001). Shift happens:

Educating teachers and integrating instructional technology. Retrieved May 29, 2003 from http://www.trek-21.wvu.edu/html/disfiles/aera2001/aera2001paper.pdf

Weigandt, C. M., Palak, D, Wells, D. L., Mitchem, K. J., Wells, J. G. (2003). Instructional technology: Building toward a higher level. Retrieved August 27, 2003, from http://www.trek-21.wvu.edu/html/research/dissefforts.htm

Wells, J. G. (1999). Trek-21 educating teachers as agents of technological change. Proposal document for PT3 Grant Program, U.S. Department of Education. Wiersma, W. (1995). Research methods in education: An introduction ( $6^{\text {th }}$ edition). Boston: Allyn and Bacon.

Wilkins, D. G., Schultz, B., \& Linduff, K. M. (1994). Art past and present $\left(2^{\text {nd }}\right.$ ed.). NY: Harry N. Abrams. 


\section{Appendix A}

\section{Indicators of Instructional Change Instrument: Lesson Sweep}

\begin{tabular}{|c|c|c|c|c|c|c|c|c|}
\hline \multirow[b]{2}{*}{ Participant Name } & \multicolumn{2}{|c|}{ Preschool } & \multicolumn{2}{|c|}{ Elementary } & \multicolumn{2}{|c|}{ Middle } & \multicolumn{2}{|l|}{ High } \\
\hline & Pre & Post & Pre & Post & Pre & Post & Pre & Post \\
\hline \multicolumn{9}{|l|}{ Curricular Area } \\
\hline \multicolumn{9}{|l|}{ Objectives (action verb/measurable) } \\
\hline \multicolumn{9}{|l|}{ Assessment $(0,1,2,3)$} \\
\hline \multicolumn{9}{|l|}{ Instructional Procedures } \\
\hline \multicolumn{9}{|l|}{ Motivating Introduction } \\
\hline \multicolumn{9}{|l|}{ Check for Prerequisite Skills (Review) } \\
\hline \multicolumn{9}{|l|}{ Present New Content } \\
\hline \multicolumn{9}{|l|}{ Guided practice } \\
\hline \multicolumn{9}{|l|}{ Independent Practice } \\
\hline \multicolumn{9}{|l|}{ Closure } \\
\hline \multicolumn{9}{|l|}{ Extensions $(0,1,2)$} \\
\hline \multicolumn{9}{|l|}{ Total Procedures } \\
\hline \multicolumn{9}{|l|}{ Total Active } \\
\hline \multicolumn{9}{|l|}{ Instructional Strategies } \\
\hline \multicolumn{9}{|l|}{ Advanced Organizer } \\
\hline Whole Group Instruction & & & & & & & & \\
\hline Peer-Mediated Instruction & & & & & & & & \\
\hline Group Discussion & & & & & & & & \\
\hline Active Responding & & & & & & & & \\
\hline Problem-Solving & & & & & & & & \\
\hline Research & & & & & & & & \\
\hline Inquiry & & & & & & & & \\
\hline Hands-on/ Manipulatives & & & & & & & & \\
\hline Dramatic Representation & & & & & & & & \\
\hline Journaling/Writing & & & & & & & & \\
\hline Student Presentation & & & & & & & & \\
\hline Teacher Demonstration & & & & & & & & \\
\hline Total Strategies & & & & & & & & \\
\hline Total Active & & & & & & & & \\
\hline IT Integrations & & & & & & & & \\
\hline CAI/Drill and Practice & & & & & & & & \\
\hline Simulation/Educational Games & & & & & & & & \\
\hline Word Processing & & & & & & & & \\
\hline Information Retrieval & & & & & & & & \\
\hline Internet Access & & & & & & & & \\
\hline E-mail & & & & & & & & \\
\hline Bulletin Boards/Listservs & & & & & & & & \\
\hline Authoring/Multimedia Development & & & & & & & & \\
\hline Desktop Publishing & & & & & & & & \\
\hline Electronic Presentations & & & & & & & & \\
\hline Video Development & & & & & & & & \\
\hline Open Lab Access & & & & & & & & \\
\hline Web-Page Development & & & & & & & & \\
\hline Total ITs & & & & & & & & \\
\hline Total Active & & & & & & & & \\
\hline Key & & & & & & & & \\
\hline $\begin{array}{l}0=\text { Absence of variable } \\
1=\text { Presence of variable } \\
2=\text { Assessment is linked } \\
3=\text { Each objective is asse }\end{array}$ & $\begin{array}{l}\text { obje } \\
\text { ed }\end{array}$ & Exten & invo & $+=$ & tive s & ent en & sement & \\
\hline
\end{tabular}




\section{Appendix B}

\section{Bloom's Taxonomy of Educational Objectives}

\begin{tabular}{|c|c|c|c|}
\hline Bloom 's Level & Learner Action & IS/ Active verbs & Level \\
\hline $\begin{array}{c}\text { Level } 1 \\
\text { (low) }\end{array}$ & $\begin{array}{l}\text { Recall content in the } \\
\text { exact form that it was } \\
\text { presented. } \\
\text { Memorization of } \\
\text { definitions, formulas, } \\
\text { or procedures are } \\
\text { examples of } \\
\text { knowledge-level } \\
\text { functioning. }\end{array}$ & $\begin{array}{l}\text { List, define, label, identify, } \\
\text { name. } \\
\text { - active organizers } \\
\text { - information retrieval }\end{array}$ & $\begin{array}{l}\text { Define or label parts of an } \\
\text { object. Concept mapping, Venn } \\
\text { diagrams, KWL charts. View } \\
\text { teacher demonstrations and } \\
\text { presentations. Drill \& practice, } \\
\text { CAI. }\end{array}$ \\
\hline Comprehension & $\begin{array}{l}\text { Restate material in } \\
\text { their own words, or } \\
\text { can recognize } \\
\text { previously unseen } \\
\text { examples of a } \\
\text { concept. }\end{array}$ & $\begin{array}{l}\text { Describe, associate, } \\
\text { categorize, summarize. } \\
\text { - active responding } \\
\text { - information retrieval } \\
\text { - whole group instruction or } \\
\text { demonstration } \\
\text { - peer- mediated activity } \\
\text { - whole group }\end{array}$ & $\begin{array}{l}\text { Given a list of examples, fill in } \\
\text { worksheet, vocabulary puzzle. } \\
\text { Virtual tour, chats, } \\
\text { writing/journaling. } \\
\text { (wg)Participate in group } \\
\text { discussion: view video, or EP. } \\
\text { (pm)Take an instructional or } \\
\text { advisory role; respond to } \\
\text { posting on discussion boards, } \\
\text { listservs, chats, emails. }\end{array}$ \\
\hline Application & $\begin{array}{l}\text { Apply rules to a } \\
\text { problem, without } \\
\text { being given the rule } \\
\text { or formula for } \\
\text { solving the problem. }\end{array}$ & $\begin{array}{l}\text { Apply, calculate, illustrate, } \\
\text { solve. } \\
\text { - problem solving } \\
\text { - open lab } \\
\text { - hands-on/manipulatives } \\
\end{array}$ & $\begin{array}{l}\text { (ps)- looking for a pattern; draw } \\
\text { a diagram, storyboarding, } \\
\text { writing, desktop publishing, } \\
\text { simulations, learn by doing. }\end{array}$ \\
\hline Analysis & $\begin{array}{l}\text { Break complex } \\
\text { concepts or situations } \\
\text { down into their } \\
\text { component parts, and } \\
\text { analyze how the parts } \\
\text { are related to one } \\
\text { another. }\end{array}$ & $\begin{array}{l}\text { Analyze, compare, separate, } \\
\text { order, explain. } \\
\text { • Internet Access } \\
\text { •research } \\
\text { • inquiry }\end{array}$ & $\begin{array}{l}\text { (r) - search strategies, inquiry, } \\
\text { collect information and analyze } \\
\text { data. }\end{array}$ \\
\hline Level 5 & $\begin{array}{l}\text { Rearrange component } \\
\text { parts to form a new } \\
\text { whole. }\end{array}$ & $\begin{array}{l}\text { Combine, modify, } \\
\text { rearrange, create, "what-if". } \\
\text { •student presentation } \\
\text { •problem-solving }\end{array}$ & $\begin{array}{l}\text { Desktop publishing, } \\
\text { authoring/multimedia, student } \\
\text { presentations, video } \\
\text { development }\end{array}$ \\
\hline $\begin{array}{c}\text { Level } 6 \\
\text { (High) }\end{array}$ & $\begin{array}{l}\text { Evaluate or make } \\
\text { judgments on the } \\
\text { worth of a concept, } \\
\text { object, etc. for a } \\
\text { purpose. }\end{array}$ & $\begin{array}{l}\text { Assess, decide, grade, } \\
\text { recommend, explain, judge } \\
\text { - student presentation } \\
\text { •problem-solving }\end{array}$ & $\begin{array}{l}\text { Peer-mediated, video } \\
\text { development, desktop or online } \\
\text { publishing, authoring/ } \\
\text { multimedia, student } \\
\text { presentations, bookmaking, e- } \\
\text { books, web page or web site } \\
\text { development, newsletters, } \\
\text { newscasts, social or community } \\
\text { education/presentation. }\end{array}$ \\
\hline
\end{tabular}

Note. From http://wiscinfo.doit.wisc.edu/teaching-academy/Assistance/course/bloomsprint.htm Retrieved, August 5, 2003. Adapted with permission. 


\section{Appendix C}

\section{The Taxonomy for Instructional Technology}

\begin{tabular}{|c|c|}
\hline Taxonomy Classification & Action Verbs that represent intellectual activity at this level. \\
\hline $\begin{array}{l}\text { Literacy } \\
\text { (Understanding technology and its } \\
\text { components) } \\
\\
\text { Level } 1 \\
\text { (low) }\end{array}$ & $\begin{array}{ll}- & \text { Apply computer terminology in oral and written communication } \\
\text { - } & \text { Consider the various uses of computers and technology in business, industry, and } \\
& \text { society } \\
\text { - } & \text { Master keyboarding, and click and drag } \\
\text { - } & \text { Use web-based search engines } \\
\text { - } & \text { Download information via file transfer protocol } \\
& \text { Operate input and output devices }\end{array}$ \\
\hline $\begin{array}{l}\text { Communication } \\
\text { (Sharing ideas, working collaboratively, and } \\
\text { forming relationships using technology) } \\
\text { Level } 2\end{array}$ & $\begin{array}{ll} & \text { Use technology tools for individual writing and personal communications } \\
\text { - } & \text { Share information electronically among students and teachers } \\
\text { - } & \text { Communicate interpersonally using electronic mail }\end{array}$ \\
\hline $\begin{array}{l}\text { Decision-Making } \\
\text { (Using technology in new and concrete } \\
\text { situations) } \\
\text { Level } 3 \\
\end{array}$ & $\begin{array}{l}\text { - } \quad \text { Apply electronic tools for research and problem-solving } \\
\text { - } \quad \text { Design effective instruction } \\
\text { - } \quad \text { Prepare an electronic spreadsheet } \\
\text { - } \quad \text { Create calendars, address books, and class schedules }\end{array}$ \\
\hline $\begin{array}{l}\text { Instruction } \\
\text { (Breaking down technology-based instructional } \\
\text { material into its components }\end{array}$ & $\begin{array}{ll}- & \text { Appraise educational software for its pedagogical strengths } \\
\text { - } & \text { Choose developmentally appropriate multimedia resources } \\
\text { - } & \text { Formulate an environment for teaching and learning using technology-based tools } \\
\text { - } & \text { Create teacher and student Web-based materials } \\
\text { - } & \text { Create text-based materials using technology } \\
\text { - } & \text { Create visual-based classroom presentations }\end{array}$ \\
\hline $\begin{array}{l}\text { Integration } \\
\text { (re-assembling technology-based instruction to } \\
\text { create new materials) } \\
\text { Level } 5\end{array}$ & $\begin{array}{ll} & \text { Assimilate technology into a personal learning style } \\
\text { - } & \text { Facilitate lifelong learning by constructing a personal schemata for using technology } \\
\text { - } & \text { Consider the consequences of inappropriate uses of technology } \\
\text { - } & \text { Enhance personal productivity with technology }\end{array}$ \\
\hline $\begin{array}{c}\text { Acculturation } \\
\text { (judging the value of technology) } \\
\text { Level } 6 \\
\text { (high) }\end{array}$ & $\begin{array}{ll} & \text { Support copyright and Fair Use laws for using technology } \\
\text { - } & \text { Debate the issues surrounding legal/ethical behavior when using technology }\end{array}$ \\
\hline
\end{tabular}

Note. From Teaching Digitally: A Guide for Integrating Technology into the Classroom (p. 120), by L. A. Tomei, 2001, Norwood, MA: Christopher-Gordon Publishers. Copyright 2001 by Christopher-Gordon Publishers. Reprinted with permission. 


\section{Appendix D}

Unit Review: Instructional Strategies and IM Integrations

\begin{tabular}{|c|c|c|c|c|c|c|c|c|c|c|c|}
\hline \multirow[t]{2}{*}{ ID\#XX } & \multicolumn{2}{|c|}{ Lesson 1} & \multicolumn{2}{|c|}{ Lesson 2} & \multicolumn{2}{|c|}{$\begin{array}{ll}\text { Lesson } 3 \\
\end{array}$} & \multicolumn{2}{|c|}{ Lesson 4} & \multicolumn{2}{|c|}{ Lesson 5} & \\
\hline & IS & $\begin{array}{l}\text { Bloom } \\
\text { Value }\end{array}$ & IS & $\begin{array}{l}\text { Bloom } \\
\text { Value }\end{array}$ & IS & $\begin{array}{l}\text { Bloom } \\
\text { Value }\end{array}$ & IS & $\begin{array}{c}\text { Bloom } \\
\text { Value }\end{array}$ & IS & $\begin{array}{l}\text { Bloom } \\
\text { Value }\end{array}$ & \\
\hline \multicolumn{11}{|l|}{$\begin{array}{r}\text { Instructional } \\
\text { Strategies }\end{array}$} & \\
\hline \multicolumn{11}{|l|}{ Advanced Organizer } & \\
\hline \multicolumn{11}{|l|}{$\begin{array}{r}\text { Whole Group } \\
\text { Instruction }\end{array}$} & \\
\hline \multicolumn{11}{|l|}{$\begin{array}{r}\text { Peer-Mediated } \\
\text { Instruction }\end{array}$} & \\
\hline \multicolumn{11}{|l|}{ Group Discussion } & \\
\hline \multicolumn{11}{|l|}{ Active Responding } & \\
\hline \multicolumn{11}{|l|}{ Problem-Solving } & \\
\hline \multicolumn{12}{|l|}{ Research } \\
\hline \multicolumn{11}{|l|}{ Inquiry } & \\
\hline \multicolumn{11}{|l|}{$\begin{array}{r}\text { Hands- } \\
\text { on/Manipulatives }\end{array}$} & \\
\hline \multicolumn{11}{|l|}{ Dramatic Presentation } & \\
\hline \multicolumn{11}{|l|}{ Journaling/Writing } & \\
\hline \multirow{2}{*}{\multicolumn{11}{|c|}{ Student Presentation }} & \\
\hline \multicolumn{5}{|l|}{ Teacher Demonstration } & & & & & & & \\
\hline \multicolumn{12}{|l|}{$\begin{array}{r}\text { Totals } \\
\end{array}$} \\
\hline & \multicolumn{2}{|c|}{ Lesson 1} & \multicolumn{2}{|c|}{ Lesson 2} & \multicolumn{2}{|c|}{ Lesson 3} & \multicolumn{2}{|c|}{ Lesson 4} & \multicolumn{2}{|c|}{ Lesson 5} & \\
\hline & IM & $\begin{array}{l}\text { Tomei } \\
\text { Rank }\end{array}$ & IM & $\begin{array}{l}\text { Tomei } \\
\text { Rank }\end{array}$ & IM & $\begin{array}{l}\text { Tomei } \\
\text { Rank }\end{array}$ & IM & $\begin{array}{l}\text { Tomei } \\
\text { Rank }\end{array}$ & IM & $\begin{array}{l}\text { Tomei } \\
\text { Rank }\end{array}$ & \\
\hline IM Integrations & & & & & & & & & & & \\
\hline CAI/Drill and Practice & & & & & & & & & & & \\
\hline $\begin{array}{r}\text { Simulations/Educational } \\
\text { Games }\end{array}$ & & & & & & & & & & & \\
\hline Word Processing & & & & & & & & & & & \\
\hline Informational Retrieval & & & & & & & & & & & \\
\hline Internet Access & & & & & & & & & & & \\
\hline Email & & & & & & & & & & & \\
\hline $\begin{array}{r}\text { Bulletin } \\
\text { Boards/Listservs }\end{array}$ & & & & & & & & & & & \\
\hline $\begin{array}{r}\text { Authoring/Multimedia } \\
\text { Development }\end{array}$ & & & & & & & & & & & \\
\hline Desktop Publishing & & & & & & & & & & & \\
\hline Electronic Presentations & & & & & & & & & & & \\
\hline Video Development & & & & & & & & & & & \\
\hline Open Lab Access & & & & & & & & & & & \\
\hline Web Page Development & & & & & & & & & & & \\
\hline Totals & & & & & & & & & & & \\
\hline
\end{tabular}




\section{Appendix E}

\section{Interview Questions, Probes}

\begin{tabular}{ll}
\hline \multicolumn{1}{c}{ Interview Question } \\
\hline 1. & $\begin{array}{l}\text { How many years did you participate in } \\
\text { Trek-21? }\end{array}$ \\
2. & $\begin{array}{l}\text { Which ITs did you use in your web-based } \\
\text { unit? }\end{array}$
\end{tabular}
unit?

3. How did you use the ITs in your unit?

4. If I followed you through a typical day in which you taught a lesson from your unit, what would you and the student(s) be doing?

5. In your opinion what component is the best strength of your unit?

6. In your opinion what does your webbased unit provide that you were not able to provide before?

7. In your opinion, to what ITs are the students most responsive?

8. How many times have you used your unit?

9. What, if any, adjustments have you made to your unit? Why?

10. Do you use or reference Bloom's taxonomy?

11. Did you use, or consider using, any of Harris' activity structures?

12. Did you find Tomei’s taxonomy helpful.

\section{Probe(s) and Follow-ups}

1a. In what capacity were you involved in Trek21 ?

1b. Consecutive years?

2a. Are there other ITs that you would like to use? 2b. Which ITs do you use most often?

2c. Which ones did you not use? Why?

3a. Is there an IT or an activity that is associated with an IT that you would like to include in your unit not covered by Trek 21.

3.b Do your students respond better to one IT over another?

4a. Would anyone else be involved? Aide, parent, substitute teacher, etc.

4b. Describe the delivery setting of your webbased lessons. Always the same?

5a. What component do you think transferred the information to the children better. What part of your unit seemed to work better?

5b. What instructional technology worked \& why?

6a. How has the integration \& delivery of your unit affected your classroom teaching?

7a. Describe a positive response that one of your students had with your unit.

8a. Have you delivered your unit the same way each time you have used it?

9a. Did active ITs help?

10a. Do you find Bloom's taxonomy appropriate for what you do?

11a. Do you find Harris’ activity structures appropriate for what you do?

12a. Do you find Tomei's taxonomy appropriate for what you do?

13. Is there anything you would like to add? 


\section{Appendix F}

Total IM, Active IM, and Non-Active IM

\begin{tabular}{|c|c|c|c|c|c|c|c|c|c|c|c|}
\hline ID \# & $\begin{array}{c}\text { Total } \\
\text { IM }\end{array}$ & $\begin{array}{l}\text { Active } \\
\text { IM }\end{array}$ & $\begin{array}{c}\text { Non } \\
\text { Active } \\
\text { IM }\end{array}$ & ID \# & $\begin{array}{c}\text { Total } \\
\text { IM }\end{array}$ & $\begin{array}{c}\text { Active } \\
\text { IM }\end{array}$ & $\begin{array}{c}\text { Non } \\
\text { Active } \\
\text { IM }\end{array}$ & ID \# & $\begin{array}{c}\text { Total } \\
\text { IM }\end{array}$ & $\begin{array}{c}\text { Active } \\
\text { IM }\end{array}$ & $\begin{array}{c}\text { Non } \\
\text { Active } \\
\text { IM }\end{array}$ \\
\hline 28 & 1.00 & 0.00 & 1.00 & 1 & 2.00 & 2.00 & 0.00 & 73 & 3.00 & 3.00 & 0.00 \\
\hline 29 & 2.00 & 2.00 & 0.00 & 2 & 1.00 & 1.00 & 0.00 & 74 & 4.00 & 4.00 & 0.00 \\
\hline 30 & 3.00 & 3.00 & 0.00 & 3 & 0.00 & 0.00 & 0.00 & 75 & 3.00 & 2.00 & 0.00 \\
\hline 31 & 0.00 & 0.00 & 0.00 & 4 & 0.00 & 0.00 & 0.00 & 76 & 1.00 & 1.00 & 0.00 \\
\hline 32 & 0.00 & 0.00 & 0.00 & 5 & 3.00 & 3.00 & 0.00 & 77 & 0.00 & 0.00 & 0.00 \\
\hline 33 & 0.00 & 0.00 & 0.00 & 6 & 4.00 & 4.00 & 0.00 & 78 & 3.00 & 3.00 & 0.00 \\
\hline 34 & 4.00 & 4.00 & 0.00 & 7 & 0.00 & 0.00 & 0.00 & 79 & 2.00 & 1.00 & 1.00 \\
\hline 35 & 0.00 & 0.00 & 0.00 & 8 & 3.00 & 3.00 & 0.00 & 80 & 2.00 & 2.00 & 0.00 \\
\hline 36 & 3.00 & 3.00 & 0.00 & 9 & 6.00 & 6.00 & 0.00 & 81 & 0.00 & 0.00 & 0.00 \\
\hline 37 & 0.00 & 0.00 & 0.00 & 10 & 3.00 & 3.00 & 0.00 & 82 & 2.00 & 2.00 & 0.00 \\
\hline 38 & 0.00 & 0.00 & 0.00 & 11 & 4.00 & 4.00 & 0.00 & 83 & 1.00 & 1.00 & 0.00 \\
\hline 39 & 2.00 & 2.00 & 0.00 & 12 & 2.00 & 2.00 & 0.00 & 84 & 1.00 & 1.00 & 0.00 \\
\hline 40 & 2.00 & 2.00 & 0.00 & 13 & 4.00 & 4.00 & 0.00 & 85 & 1.00 & 0.00 & 1.00 \\
\hline 41 & 2.00 & 2.00 & 0.00 & 14 & 1.00 & 1.00 & 0.00 & 86 & 2.00 & 2.00 & 0.00 \\
\hline 42 & 2.00 & 2.00 & 0.00 & 15 & 3.00 & 3.00 & 0.00 & 87 & 0.00 & 0.00 & 0.00 \\
\hline 43 & 2.00 & 2.00 & 0.00 & 16 & 1.00 & 0.00 & $1: 00$ & 88 & 4.00 & 4.00 & 0.00 \\
\hline 44 & 2.00 & 1.00 & 1.00 & 17 & 3.00 & 3.00 & 0.00 & 89 & 3.00 & 3.00 & 0.00 \\
\hline 45 & 2.00 & 1.00 & 1.00 & 18 & 0.00 & 0.00 & 0.00 & 90 & 4.00 & 4.00 & 0.00 \\
\hline 46 & 3.00 & 3.00 & 0.00 & 19 & 1.00 & 1.00 & 0.00 & 91 & 2.00 & 2.00 & 0.00 \\
\hline 47 & 3.00 & 3.00 & 0.00 & 20 & 2.00 & 2.00 & 0.00 & 92 & 5.00 & 5.00 & 0.00 \\
\hline 48 & 3.00 & 3.00 & 0.00 & 21 & 2.00 & 2.00 & 0.00 & 93 & 1.00 & 1.00 & 0.00 \\
\hline 49 & 2.00 & 2.00 & 0.00 & 22 & 1.00 & 1.00 & 0.00 & 94 & 1.00 & 0.00 & 1.00 \\
\hline 50 & 3.00 & 3.00 & 0.00 & 23 & 4.00 & 4.00 & 0.00 & 95 & 0.00 & 0.00 & 0.00 \\
\hline 51 & 3.00 & 2.00 & 1.00 & 24 & 3.00 & 3.00 & 0.00 & 96 & 3.00 & 2.00 & 0.00 \\
\hline 52 & 3.00 & 3.00 & 0.00 & 25 & 1.00 & 1.00 & 0.00 & 97 & 2.00 & 2.00 & 0.00 \\
\hline 53 & 2.00 & 2.00 & 0.00 & 26 & 2.00 & 2.00 & 0.00 & 98 & 4.00 & 4.00 & 0.00 \\
\hline 54 & 0.00 & 0.00 & 0.00 & 27 & 4.00 & 4.00 & 0.00 & 99 & 2.00 & 2.00 & 0.00 \\
\hline 55 & 2.00 & 2.00 & 0.00 & $n=27$ & & & & 100 & 4.00 & 4.00 & 0.00 \\
\hline 56 & 3.00 & 3.00 & 0.00 & & & & & 101 & 3.00 & 3.00 & 0.00 \\
\hline 57 & 0.00 & 0.00 & 0.00 & & & & & 102 & 3.00 & 3.00 & 0.00 \\
\hline 58 & 2.00 & 2.00 & 0.00 & & & & & 103 & 0.00 & 0.00 & 0.00 \\
\hline 59 & 2.00 & 2.00 & 0.00 & & & & & 104 & 2.00 & 2.00 & 0.00 \\
\hline 60 & 2.00 & 2.00 & 0.00 & & & & & 105 & 2.00 & 2.00 & 0.00 \\
\hline 61 & 1.00 & 1.00 & 0.00 & & & & & 106 & 1.00 & 0.00 & 1.00 \\
\hline 62 & 0.00 & 0.00 & 0.00 & & & & & 107 & 4.00 & 4.00 & 0.00 \\
\hline 63 & 0.00 & 0.00 & 0.00 & & & & & $n=35$ & & & \\
\hline 64 & 1.00 & 1.00 & 0.00 & & & & & & & & \\
\hline 65 & 2.00 & 2.00 & 0.00 & & & & & & & & \\
\hline 66 & 3.00 & 3.00 & 0.00 & & & & & & & & \\
\hline 67 & 0.00 & 0.00 & 0.00 & & & & & & & & \\
\hline 68 & 3.00 & 3.00 & 0.00 & & & & & & & & \\
\hline 69 & 2.00 & 2.00 & 0.00 & & & & & & & & \\
\hline 70 & 1.00 & 1.00 & 0.00 & & & & & & & & \\
\hline 71 & 1.00 & 0.00 & 1.00 & & & & & & & & \\
\hline 72 & 3.00 & 3.00 & 0.00 & & & & & & & & \\
\hline$n=45$ & & & & & & & & & & & \\
\hline
\end{tabular}


Outline of key competencies, experience, and products for

Sharon Teabo

\section{Education}

- Ed.D. Technology Education, Instructional Technology \& Design

- M.F.A. Studio Arts

- B.F.A. Visual Communication

Certified Trainer

- Instructional Performance Systems, Inc. (IPSI), (Pedagogy-based Instruction)

- Module-Based Workforce Development Skills

- Leaning to Learn: Critical Skills for the Quality Work Force

Additional Knowledge and Skills:

- Web-Based Curriculum, Instruction \& Assessment

- Telelearning Design, Instruction, \& Management

- Multimedia Design \& Integration

\section{Employment/Experience}

Graduate Teaching and Advising Experience

- $\quad(F / T)$ Assistant Professor, Arts \& Sciences, Computers in Education, Shenandoah University, Winchester, VA.

- $\quad(P / T)$ Consultant/Instructor, Technology Education, West Virginia University, Morgantown, WV.

Administrative Experience, Undergraduate Teaching and Advising Experience

- $\quad(F / T)$ Assistant Director, Shepherd College-South Branch, Petersburg, WV.

- $\quad(P / T)$ Shepherd College, Shepherdstown, WV; The Community \& Technical College at Shepherd, Martinsburg, WV; Shepherd College-South Branch, Petersburg, WV.

\section{Presentations/Publications}

- Presentations at regional, national, \& international conferences on Best Practices, Exploring the Visual Future, Educational Multimedia/Hypermedia, Distance Learning, Model Partnerships, Module-based Instruction, Web-based Instruction.

- Published papers and poster session in print and on CD through the International Visual Literacy Association, Ed-Media \& Ed Telecommunications, National Educational Computing Conference, and multiple works in art media books.

\section{Products}

- Multiple web sites developed to supplement information and delivery of content for workshops and for courses.

- Fully web-based course sites developed.

- Web-design \& implementation of business and education sites.

\section{Professional Organizations}

- International Visual Literacy Association (IVLA)

- Association for the Advancement of Computing in Education (AACE)

- Phi Kappa Phi National Honor Society (PKP)

- International Society for Technology in Education (ISTE) 